SLOVO, sv. 68 (2018), 99-169, Zagreb 2018.

Josip GALIĆ

Odjel za kroatistiku Sveučilišta u Zadru

jgalic@unizd.hr
UDK 811.163.42’344

Izvorni znanstveni članak

Primljen: 31. svibnja 2018. Prihvaćen: 29. studenoga 2018.

\title{
FONOLOŠKE OSOBITOSTI ZBORNIKA U BERČIĆEVOJ ZBIRCI BR. 5 I FATEVIĆEVA ZBORNIKA DUHOVNOGA S̆TIVA*
}

U radu se analiziraju i međusobno uspoređuju fonološke osobitosti Zbornika u Berčićevoj zbirci br. 5 (15. st.) i Fatevićeva zbornika duhovnoga štiva (1617.). Stanje u obama zbornicima usto se uspoređuje s rezultatima dosadašnjih istraživanja fonoloških osobitosti hrvatskoglagoljskih tekstova liturgijskoga karaktera te sa stanjem u drugim zbornicima neliturgijskoga štiva. Analiza pokazuje da se i u jednome i u drugome zborniku na fonološkoj razini miješaju obilježja crkvenoslavenskoga i hrvatskoga (čakavskoga) jezika, s tim da je obilježjā hrvatskoga (čakavskoga) jezika u obama zbornicima znatno više, a osobito se sustavno ona pojavljuju u mlađem, Fatevićevu zborniku. Na zadarsko područje, odnosno na južnije srednjočakavsko područje kao mjesto nastanka zbornikā upućuje ikavsko-ekavska zamjena jata s prevlašću ikavskih odraza te zamjena $\varepsilon>a$ iza l nakon prijelaza korijenske suglasničke skupine $\mathrm{kl} \mathrm{u} \mathrm{kl}$.

Ključne riječi: fonologija, čakavsko-crkvenoslavenski amalgam, neliturgijski zbornici, Zbornik u Berčićevoj zbirci br. 5, Fatevićev zbornik duhovnoga štiva

* Ovaj je rad sufinancirala Hrvatska zaklada za znanost projektom IP-2014-09-1946 (Dijalektološka i jezičnopovijesna istraživanja hrvatskoga jezika, voditelj: prof. dr. sc. Josip Lisac). Prva je inačica rada nastala u okviru seminara na kolegiju »Fonologija« na Poslijediplomskome doktorskom studiju lingvistike na Filozofskome fakultetu Sveučilišta u Zagrebu. Nositeljici kolegija, Zrinki Jelaski, te dvama anonimnim recenzentima časopisa Slovo zahvaljujem na korisnim komentarima i primjedbama kojima su unaprijedili rad. U razrješavanju pojedinih nedoumica prilikom pisanja rada konzultirao sam se s Milanom Mihaljevićem, kojemu također zahvaljujem. Odgovornost za preostale nedostatke isključivo je autorova. Zahvaljujem također vodstvu Staroslavenskoga instituta na ustupanju neobjavljene transliteracije Petrinićeva zbornika koju je priredio Johannes Reinhart te Katarini Lozić Knezović na ustupanju vlastite neobjavljene transliteracije Klimantovićeva zbornika I. 


\section{UVOD}

U bogatoj riznici hrvatskoglagoljskih tekstova zbornici neliturgijskoga štiva zauzimaju posebno mjesto. Osim svojom sadržajnom raznovrsnošću, zbornički tekstovi pozornost privlače i zbog zanimljiva jezičnoga sljubljivanja narodnoga i crkvenoslavenskoga jezika - tzv. čakavsko-crkvenoslavenskoga amalgama (usp. DAMJANOVIĆ 1984), svojevrsne »knjiške koinē s čakavskom potkom, u koju su utkani elementi crkvenoslavenske strukture« (HERCIGONJA 1983: 165). Upravo je struktura čakavske ili ponegdje čakavsko-kajkavske potke nerijetko pomagala istraživačima u lociranju mjesta nastanka zborničkih tekstova. Tako se, primjerice, među ostalim, i po strukturi elemenata iz narodnoga jezika zaključuje da su Vinodolski i Petrisov zbornik nastali na »sjevernom dijelu frankapanske državine « (HERCIGONJA 1983: 345), a Borislavićev, Oxfordski, Ljubljanski, Kolunićev, Petrinićev i, vjerojatno, Tkonski zbornik na ličkome području (usp. DAMJANOVIĆ 2008: 303). U ovom ćemo se radu posvetiti fonološkim osobitostima dvaju neliturgijskih zbornika koji su nastali na zadarskome području - Zbornika u Berčićevoj zbirci br. 5 i Fatevićeva zbornika duhovnoga štiva.

Zbornik u Berčićevoj zbirci br. 5 (dalje Berčićev zbornik) jedan je od rukopisa iz zbirke glagoljskih tekstova hrvatskoga glagoljaša i filologa Ivana Berčića koji se čuva u Ruskoj nacionalnoj knjižnici u Petrogradu pod signaturom Berč. br. 5. Zbornik ima 78 listova formata $15,7 \times 12 \mathrm{~cm}$, a pisalo ga je najmanje sedam ruku (usp. VJALOVA 2016: 41). Tekst je pisan jednostupačno, osim na listovima 30r-33v, na kojima je ispisan dvostupačno. Rukopis je općenito pretrpio različita oštećenja, a početak prvoga i završetak posljednjega teksta u zborniku nedostaju (usp. VJALOVA 2016: 41). U rukopisu nema eksplicitnih podataka o tome tko je i kada zapisao tekstove u zborniku. Milčetić (1955: 108 ) ističe da »miješanje uglaste i kurzivne glagoljice pokazuje na XV. vijek«, a takvu dataciju prihvaćaju i drugi (usp. HCSL 2014: 45; NAZOR 2016: 19). Nastanak rukopisa obično se vezuje uz zadarsko područje, i to prije svega na temelju bilješke s f. 25r (to pisa Šimun žakan iz Sali kada 〈e〉 doša gospodinu dominu Pavlu Radiniću parohiênu ot Bana i ot Ždreca čfog (=1584)) iz koje se zaključuje da se zbornik u 16. stoljeću nalazio u okolici Zadra (usp. GRABAR 1967: 138; NAZOR 2016: 19-20). ${ }^{1}$ U zborniku su zapisana 34 teksta, i to, među ostalim, apokrifne priče, eshatološke vizije, legende o životima svetaca, tumačenja kršćanskih molitava, propovijedi, religiozne pjesme, pouke o

1 Biserka Grabar (1967: 138) na temelju jezične analize apokrifa o djelima Andrije i Mateja u gradu ljudoždera ističe da na južnije čakavsko (možebitno upravo zadarsko) područje upućuju i brojni ikavizmi. 
ponašanju i prenja (usp. MILČETIĆ 1955; ŠTEFANIĆ 1969; KAPETANOVIĆ; MALIĆ; ŠTRKALJ DESPOT 2010; BADURINA STIPČEVIĆ 2013; DÜRRIGL 2013; VJALOVA 2016).

Fatevićev zbornik duhovnoga štiva (dalje Fatevićev zbornik) hrvatskoglagoljski je neliturgijski zbornik koji je 1617. g. prepisao ravski kapelan don Mikula Fatević iz Luke na Dugome otoku. Zbornik ima 80 listova formata $20,7 \times 15,4 \mathrm{~cm}$. Neki listovi u zborniku nedostaju, a mnogi su oštećeni od vlage (usp. FRANOV-ŽIVKOVIĆ 2016: 9). U sadržajnome se smislu zbornik sastoji od različitih propovjednih tekstova, apokrifnih priča, legendi i Fatevićeva prijepisa Zrcala duhovnoga, djela fra Angela Milanesea koje je s talijanskoga ili latinskoga (usp. ŠTEFANIĆ 1970: 60) preveo Ivan Žorulić Pažanin. ${ }^{2}$ Propovjedne tekstove, apokrifne priče i legende Fatević je prepisao iz starijih matica pa se u literaturi ističe da su jezična i grafijska rješenja u tim dijelovima zbornika starija u odnosu na ona iz teksta Zrcala, koji je jezično mlađi, čakavski, bliži Žoruliću i Fateviću (usp. ŠTEFANIĆ 1970: 60). Zbornik se čuva u Arhivu Hrvatske akademije znanosti i umjetnosti pod signaturom IV a 124.

Premda je znanstvena javnost s obama zbornicima upoznata razmjerno davno, ni jedan ni drugi do najnovijih vremena nisu privlačili osobitu pozornost istraživača. Osim kratkih opisa Ivana MILČETIĆA (1955), i Svetlane O. VJALOVE (2006), o Berčićevu su zborniku još pisali Biserka GRABAR (1967), koja je, među ostalim, i jezično analizirala apokrif o djelima Andrije i Mateja u gradu ljudoždera, Amir KAPETANOVIĆ (2010), koji je analizirao odnos pjesama iz Pariške pjesmarice i Berčićeva zbornika, te Nikola MLADINEO $(2015,2016)$, koji je uspoređivao prijepise apokrifnoga teksta Abrahamove vizije u pet hrvatskoglagoljskih neliturgijskih zbornika, među ostalim i u Zborniku u Berčićevoj zbirci br. 5. Godine 2016. Sveučilište u Zadru i Stalna izložba crkvene umjetnosti objavili su dvosveščano faksimilno i transliterirano izdanje s uvodnim tekstovima Anice NAZOR (2016) i Svetlane O. VJALOVE (2016), koja je i transliterirala zborničke tekstove (BZ 2016). Gotovo identičnu sudbinu u znanstvenoj je literaturi imao i Fatevićev zbornik. Osnovne informacije o tome zborniku donijeli su Ivan MILČETIĆ (1911: 340-344), Rudolf STRO-

${ }^{2}$ U zborniku se na f. 44r čita da Zrcalo duhovno - pripisa iz latinskoga u slovisnki (sic!) počtovani g(ospodi)n' Ivan Žorulić Pažanin. Dürrigl ističe da bi izraz latinski doista mogao upućivati na zaključak da je djelo prevedeno s latinskoga predloška, ali podsjeća da su »senjski tiskari pod izrazom 'latinski' podrazumijevali talijanski jezik (dok je latinski za njih bio 'dijački').« (DÜRRIGL 2017: 24). S obzirom na to da je djelo bilo dostupno Žoruliću, Dürrigl (2017: 25) vjerojatnijim smatra da je predložak bio talijanski (usp. također ŠTEFANIĆ 1970: 60). Takvom bi zaključku mogla pridonijeti i činjenica da Herbert Grabes (1982) »djelo (...) ne spominje u (...) iscrpnom katalogu latinskih djela koja u naslovu imaju izraz speculum.« (DÜRRIGL 2017: 255). 
HAL (1915: 173-176) i Vjekoslav ŠTEFANIĆ (1970: 57-60). U novije je pak vrijeme Lucija TURKALJ (2008) uspoređivala prijepise starozavjetnoga apokrifnog teksta o životu Adama i Eve u Žgombićevu i Fatevićevu zborniku. Andrea RADOŠEVIĆ (2012) analizirala je korizmene propovijedi u Fatevićevu zborniku, utvrdivši pritom da se radi o prijepisima iz glagoljskoga $\mathrm{Ko}$ rizmenjaka, dok se Marija-Ana DÜRRIGL (2017) bavila teološko-poučnim odlomkom o ovozemaljskome čistilištu iz Zrcala duhovnoga. Godine 2016. objavljeno je faksimilno i transliterirano izdanje zbornika (FZ 2016) s uvodnim tekstom Grozdane FRANOV-ŽIVKOVIĆ (2016).

\section{METODOLOGIJA I CILJEVI}

U analizi fonoloških osobitosti služili smo se spomenutim transliteracijama Svetlane O. Vjalove (Berčićev zbornik, BZ 2016), odnosno Grozdane Franov-Živković (Fatevićev zbornik, FZ 2016). Fonološke osobitosti zbornika uglavnom su obrađene sintetičkom metodom (usp. KUŠTOVIĆ 2013: 208). ${ }^{3}$ To znači da zbornički tekstovi ni u Berčićevu ni u Fatevićevu zborniku nisu analizirani zasebno, nego je analiza provedena na razini zbornikā u cjelini. Ipak, eventualne fonološke razlike među pojedinim zborničkim tekstovima na razini jednoga zbornika nisu zanemarene, nego se na njih upozorava svugdje gdje je uočeno da su razlike takve da se ne mogu smatrati slučajnošću.

Uzimajući u obzir vremenski razmak u kojem su zbornici nastali, u analizi polazimo od pretpostavke da se u Berčićevu zborniku učestalije ostvaruju fonološka obilježja hrvatskoga crkvenoslavenskog jezika, dok je u Fatevićevu zborniku udio takvih elemenata manji. Stanje u obama zbornicima nastojat će se usporediti sa stanjem u hrvatskim crkvenoslavenskim tekstovima liturgijskoga sadržaja te osobito sa stanjem u drugim zbornicima neliturgijskoga štiva. Pritom ćemo se uglavnom osloniti na rezultate istraživanja drugih istraživača, a ondje gdje to bude moguće i sami ćemo iz drugih neliturgijskih zborničkih tekstova izdvojiti primjere koje budemo smatrali važnima za naše istraživanje. ${ }^{4} \mathrm{~S}$ obzirom na to da su oba zbornika - sudeći po zapisima pisara

3 Alternativna bi toj metodi u ispitivanju jezičnih osobitosti zborničkih neliturgijskih tekstova bila metoda parcelacije, koja »pretpostavlja da pri jezikoslovnoj raščlambi nekoga kodeksa zborničkoga tipa svaki članak valja istraživati posebice kako bi se na taj način došlo 'do posebne jezične slike’ svakog priloga u zborniku« (HERCIGONJA 1983: 299; usp. također KUŠTOVIĆ 2013: 208).

4 Osim transliteracijama rukopisa kojima se ovdje ponajprije bavimo, služili smo se također i transliteracijom Tkonskoga (usp. SAMBUNJAK 2001), Ivančićeva (usp. KOSIĆ 2010), Klimantovićeva I. i Petrinićeva zbornika. 
(Fatevićev zbornik), odnosno po mišljenjima dosadašnjih istraživača (Berčićev zbornik) - nastala na zadarskome području, nastojat će se utvrditi fonološka obilježja koja upućuju na to područje.

Uz sva se oprimjerenja u zagradama donosi kratica zbornika u kojem je primjer potvrđen te broj lista na kojem se primjer nalazi.

\section{GLASOVNA I FONOLOŠKA VRIJEDNOST GLAGOLJSKIH SLOVA I SLOVNIH SKUPINA}

U hrvatskoglagoljskim tekstovima, pa tako i u Berčićevu i Fatevićevu zborniku, barem je donekle sporna glasovna vrijednost slova $\mathbf{3}, \mathbf{8}, \mathrm{IP}$, 由, $\mathrm{P}, \mathrm{u}$, I ('), B i ll, pa ćemo se u ovome poglavlju upravo njima posvetiti. ${ }^{5}$

\subsection{Slovo 3}

Slovo 3 u Berčićevu i Fatevićevu zborniku, kao i u drugim hrvatskoglagoljskim tekstovima, glasovno se može ostvariti na dva načina. Na početku riječi i iza znakova za samoglasnike obično se izgovara kao [je], a u ostalim položajima kao [e] (usp. HCSL 2014: 61). Na izgovor [je] upućuju barem dvije činjenice. ${ }^{6}$ Prva se odnosi na pojavljivanje slovne skupine IP¥ umjesto 3 , kao u (1), s tim da je takvo što u Berčićevu zborniku potvrđeno samo jednom, dok je u Fatevićevu zborniku potvrda razmjerno mnogo. Druga se pak činjenica odnosi na ostvarivanje slova $\exists$ na mjestu praslavenskoga slijeda *dje, odnosno na njegovo smjenjivanje na tome položaju sa slovnom skupinom $\mathrm{IPF}^{7}$, kao u (2):

5 S druge strane, kako ističe Mihaljević (HCSL 2014: 61), "nesporna je glasovna vrijednost

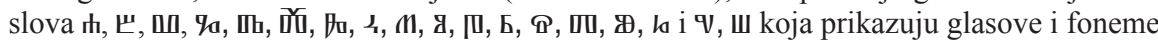

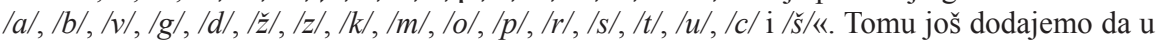
Berčićevu i Fatevićevu zborniku nije sporna glasovna vrijednost slova $\Phi$, kao ni fonološki položaj glasa $[f]$ koji ono označava. U glagoljskim tekstovima liturgijskoga karaktera, osobito u starijim razdobljima, slovo se $\Phi$ nerijetko zamjenjuje slovom [u pa istraživači glas [f] određuju kao rubnu pojavu u glasovnome sustavu hrvatskoga crkvenoslavenskog jezika, a fonem $/ f /$ ne smatraju organskim dijelom fonološkoga sustava toga jezika (usp. HCSL 2014: 66).

${ }^{6}$ Mihaljević ističe da u hrvatskoglagoljskim tekstovima na čitanje [je], osim dviju činjenica koje navodimo u nastavku, ukazuju i sporadična pojavljivanja latiničnoga $e$ na početku riječi te bilježenje $\exists$ umjesto IPJ za grčko ili latinsko ge u posuđenicama (HCSL 2014: 61-62). U Berčićevu i Fatevićevu zborniku takve primjere nismo pronašli.

7 Smjenjivanje sa slovnom skupinom IP马 u tome je položaju potvrđeno samo u Fatevićevu zborniku. 
(1) jedenîu (CFat 11v), jevanjelie (CFat 14v), jepesi (CFat 20r), jezofatski (CFat 20v), jerusolim (CFat 23r), božije (CFat 32r), večnije (CFat 32v), jedan (CFat 44v, 46v, 47r), jedanadeste (CFat 45r), jenu (CFat 49r), vijen (CFat 49r, 49v), jesam (CFat 66r), jeremiê (CFat 67v), jeûpat (CFat 72v), jere (CFat 76v)

(2) osuenie (CBč 18v), hoeniemb (CBč 2v), hoen'ê (CBč 69r), roeni (CBč $72 \mathrm{r})$; nareena $(\mathrm{CFat} 1 \mathrm{v})$, utvrjenie (CFat 3r), utvreniê (CFat 3r), roene $(\mathrm{CFat} 5 \mathrm{v})$, ograeno $(\mathrm{CFat} 13 \mathrm{v})$, rasuene $(\mathrm{CFat} 15 \mathrm{v})$, osloboen (CFat $21 \mathrm{r})$, gospoe (CFat 8v, 21r, 24r, 27v), roen (CFat 27r, 29r), rasrjenie (CFat 28v), osueniê (CFat 38v), žeje (CFat 40r), izvaeno (CFat 44r), vijen $(\mathrm{CFat} 49 \mathrm{v})$, poroeniê $(\mathrm{CFat} 59 \mathrm{v}, 60 \mathrm{r})$.

\subsection{Slovo 8}

Slovo 8 u Berčićevu i Fatevićevu zborniku, kao i u drugim hrvatskoglagoljskim tekstovima, glasovno se može ostvariti na tri načina, kao [i], kao [j] i kao [ji] (usp. HCSL 2014: 62). Izgovor [j] valja pretpostaviti ispred slova te iza samoglasnika na kraju sloga, kao u (3) (usp. HCSL 2014: 62). Na takav izgovor ukazuje i sporadično zamjenjivanje slova 8 slovom IIP u tome položaju, kao u (4), te njegovo pojavljivanje na mjestu praslavenske skupine * $d j$, kao u (5) (usp. HCSL 2014: 62):

(3) ioba (CBč 70r), poslušaite (CBč 4r), prev(e)likoi (CBč 12v), $n(e) b(e) s k o i$ (CBč 13v), p(o)m(i)lui (CBč 33r), raduite (CBč 60v), varui $(\mathrm{CBč} 71 \mathrm{r})$, nailipša $(\mathrm{CBč} 77 \mathrm{v})$; ioahim (CFat 5v), maiko (CFat 1r), naiti (CFat 4r), slavnoi (CFat 8v), raiskim (CFat 11v), divoikama (CFat 19v), čekaite (CFat 20v), razboinici (CFat 29r)

(4) pokoĵ $^{8}$ (CBč 25r), naviĵ (CBč 54r), jîj’'mo (CBč 73v); tvoĵom (CFat 20r), svoêj (CFat $47 \mathrm{v})$, prgatorîj (CFat $65 \mathrm{v})$

(5) roistvo $(\mathrm{CBč} 75 \mathrm{v})$, povii $(\mathrm{CBč} 15 \mathrm{r}, 15 \mathrm{v}, 36 \mathrm{r})$, vii $(\mathrm{CBč} \mathrm{38r,} \mathrm{59v);} \mathrm{roi-}$ stva $(\mathrm{CBč} 4 \mathrm{v})$, povii $(\mathrm{CFat} 11 \mathrm{v})$, ii 'jedi' (11v).

Izgovor [ji] ostvaruje se također iza samoglasnika, i to u primjerima kao što su moihb (CBč 5r), svoima (CBč 11v), kains (CBč 17v), m(a)rii (CBč 50r); doila (CFat 1v), kain (CFat 10r), doiti 'dojiti' (CFat 10r), goiti (CFat 10r), mariino (CFat 20v), uidahu 'ujedahu' (CFat 40r). Takvo čitanje potvrđuje pojavljivanje slova 8 na mjestu praslavenskoga slijeda *dji kojemu prethodi samoglasnik, kao u (6) (usp. HCSL 2014: 62):

8 Primjer je dvaput potvrđen u bilješci koju je kurzivnom glagoljicom ispisao Šimun, žakan iz Sali. 
(6) tuim' (CBč 7r), gospoi (CBč 68v); gospoi (CFat 8v), tuih (CFat 28v).

Zbog dvojakoga se glasovnog ostvarivanja slova 8 iza samoglasnika u nekim primjerima samo iz konteksta može razaznati pravo značenje riječi. Tako je, primjerice, s oblikom doiti, kojim u Fatevićevu zborniku može biti zabilježen leksem sa značenjem 'dojiti' (CFat 10r), no znatno se češće njime bilježi leksem sa značenjem 'doći' (CFat 10r, 44r, 45v, 46r). Slično je sa zamjeničkim oblicima moi i tvoi, kod kojih se samo iz konteksta može zaključiti je li riječ o jednini ili množini.

\subsection{Slovo IIP}

Slovo IIP u Berčićevu i Fatevićevu zborniku redovito ima glasovnu vrijednost $[j]$ te je potvrđeno u sljedećim položajima: 1) na mjestu latinskoga i grčkoga $g$ koje se nalazi ispred prednjih samoglasnika, kao u (7) (usp. DAMJANOVIĆ 2008: 57; HCSL 2014: 63); 2) na apsolutnome početku riječi, gdje se njime bilježi protetsko $[j]$, kao u $(8) ; 3)$ na mjestu praslavenske skupine $* d j$, kao u (9):

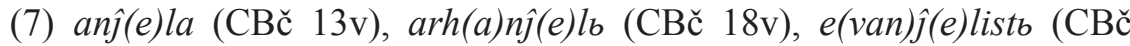
20r); anjel (CFat 1r), anjelski (CFat 1v), evanjelista (CFat 5v)

(8) ĵiden'ê (CBč 7r), jiiimo (CBč 18r), jiis'ti (CBč 34r), ĵili (CBč 39r), jistvina (CBč 53v), jiz'di (CBč 52r), jiz'diti (CBč 56v); jîh (CFat 10v), jivan (CFat 14v, 48r), jiducici (CFat 10v), jideniû (CFat 22r), jisti 'jesti' (CFat 25v), jistinu (CFat 25v), jime (CFat 26r), jiı̌s cete (CFat 56r) ${ }^{9}$

(9) meĵ' (CBč 39v); žeje (CFat 40r), vijen (CFat 49v).

Osim slovom IIP, u Berčićevu i Fatevićevu zborniku izgovor [j], kako smo već istaknuli, ispred samoglasnika $o$ i iza drugih samoglasnika obično se bilježi slovom 8 , kao u (10). Između dvaju samoglasnika od kojih je drugi $e$ ili $i$ te na početku riječi ispred $e$ najčešće izgovor $[j]$ nije nikako označen ${ }^{10}(11)$, dok je pred samoglasnicima $a$ i $u »$ jotacija gotovo uvijek vidljiva iz grafije, jer se, osim sporadične uporabe đerva ispred slova th $\mathrm{i} \boxplus$, skupine $[j a]$ i $[j u]$ redovito bilježe slovima \& i Пు (HCSL 2014: 64). U Berčićevu se zborniku, kao i u brojnim

\footnotetext{
${ }^{9}$ U Berčićevu se zborniku, kako je vidljivo iz navedenih primjera, slovom IIP protetsko $j$ bilježi isključivo pred korijenima êd-i êzd-, što je uobičajena situacija i u hrvatskoglagoljskim tekstovima liturgijskoga karaktera (usp. HCSL 2014: 63), dok se u Fatevićevu zborniku, očito pod utjecajem narodnoga jezika, ono bilježi i u drugim primjerima.

${ }^{10}$ Vrlo se rijetko događa da glas $j$ nije zabilježen između dvaju samoglasnika od kojih je drugi a: priati (CFat $14 \mathrm{v}, 27 \mathrm{r})$.
} 
drugim hrvatskoglagoljskim tekstovima (usp. HCSL 2014: 64), glas $j$ između suglasnika i znakova za samoglasnike može označiti i jerom, ${ }^{11}$ kao u (12):

(10) ioba (CBč 70r), poslušaite (CBč 4r); Ioahim (CFat 5v), slavnoi (CFat $8 \mathrm{v})$

(11) tuim' (CBč 7r), osuens (CBč 47r), es(a)mb (CBč 31r); svoega (CFat 1r), goiti (CFat 10r), edan (CFat 20r)

(12) prut'em' (CBč 9v), v'z'vap'et'(CBč 16r), kop'em'(CBč 21r), vesel'e (CBč 59r), počten'e (CBč 71v).

\subsection{Slova 而 i $\mathrm{P}$}

Kako je poznato, slova 由t i P u hrvatskoglagoljskim tekstovima imala su glasovnu vrijednost dentala $l$ i $n$ i palatala $l$ i $n$ (usp. HCSL 2014: 65). Na glasovnu vrijednost [l] i [ń] u Berčićevu i Fatevićevu zborniku upućuje nekoliko činjenica: 1) smjenjivanje slova $\boxplus$ i 四 iza th i P, kao u (13); 2) palataliziranje suglasnika ispred 由ा i $\mathrm{P}$, kao u (14); 3) provođenje prijeglasa iza th i $\mathrm{P}$ (usp. HCSL 2014: 65), kao u (15). U Berčićevu zborniku rijetko na glasovnu vrijednost [l] i [ń] ukazuju još i primjeri bilježenja znakova za jer između 由! i $\mathbf{P}$ i znakova za samoglasnike, kao u (16):

(13) lûb'vi (CBč 72r) lub'vo (CBč 70r), og'nû (CBč 30r) og'nu (CBč 41r); zlublenika (CFat 1r) lûblenik (CFat 37r), ludi (CFat 31v) lûdi (CFat 30r)

(14) pošli (CBč 50v) poslati (CBč 28r), š’ nimb (CBč 24v) s' neba (CBč 28r), višnega (CBč 13r) visinê (CBč 20r); mišlahu (CFat 24v) $\sim$ smislanih (CFat 28r), današni (CFat 27v) danas (CFat 2r), š nim (CFat 21r) s nami (CFat 23r)

(15) og'nem' (CBč 73r) sinom' (CBč 27v), sud'nemb (CBč 15v) smr 'tnom' (CBč 5r); kralevb (CBč 70r) iv (a)novb (CBč 17v); kraleva (CFat 3r) ivanovih (CFat 21r), ognem (CFat 14r), kumpanem (CFat 52v) sinom (CFat 12r), zakonom (CFat 13v)

(16) l'udi (CBč 47r), čin'u (CBč 65v).

\subsection{Slovo 出}

Slovo ư u Fatevićevu zborniku uvijek ima glasovnu vrijednost [ć]. Time se taj zbornik razlikuje od glavnine srednjovjekovnih i ranonovovjekovnih hr-

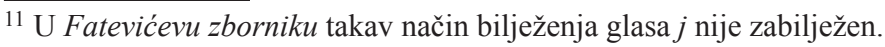


vatskoglagoljskih tekstova u kojima se isto slovo, osim kao [ć], moglo čitati i

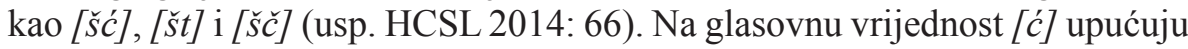
barem dvije činjenice: 1) redovito bilježenje izgovora [šć] slovnom skupinom шய' (a ne slovom 'u', kako je uobičajeno u starijim hrvatskoglagoljskim tekstovima), kao u (17); 2) morfonološke smjene tipa (18): ${ }^{12}$

(17) odpušĉenie (CFat 1r), pokršĉeni (CFat 2r), godišĉa (CFat 5r, 45r), navišcena (CFat 5v), ošĉe (CFat 10r, 31v, 32r), šĉa (CFat 10v), išçucim (CFat 19v), očišceni (CFat 44v), šcit (CFat 66r)

(18) posvetil (CFat 8r) posvecene $(\mathrm{CFat} 30 \mathrm{v})$; vratiti $(\mathrm{CFat} 41 \mathrm{v}) \sim$ vraĉahu (CFat 25v); smuti (CFat 42v) smuĉeni (CFat 6r).

U Berčićevu zborniku stanje je nešto drugačije. U glavnini primjera slovo ư ima glasovnu vrijednost [ć], no nerijetko se njime bilježi i izgovor [ [̌́ć]. Na izgovor [ [̌́ć] ukazuju morfonološke smjene tipa (19) te sporadični primjeri bilježenja toga izgovora slovnom skupinom ш'ய' (20).

(19) otpustitb (CBč 7v) otpuĉenie (CBč 6r), čistoti (CBč 54v) očiĉens (CBč 31v)

(20) očišçevaše (CBč 36r) ( očicena CBč 47r), smet'lišči (CBč 70r), sudiš'ce (CBč 70r) ( besedeliĉe CBč 70r), oš 'ĉê (CBč 70r).

Ni u jednome ni u drugome zborniku nisu zabilježeni primjeri bilježenja

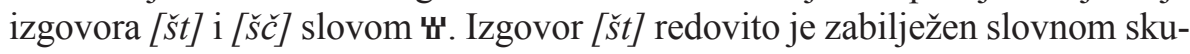
pinom шात, s tim da se u Berčićevu zborniku ta skupina ostvaruje isključivo u riječima stranoga podrijetla (meš’ tre CBč 29r, kaš’ tiga CBč 61r, ištoriju CBč $77 \mathrm{v}$ ), dok je u Fatevićevu zborniku potvrđena i u domaćim riječima u kojima je došlo do prijelaza starije suglasničke skupine čbt $\mathrm{u} \check{s}^{13}{ }^{13}(\check{s} t u \hat{u} \mathrm{CFat} 6 \mathrm{v}$, štanpi CFat 44r, pištule CFat 44r, sakrštan CFat 52v). Izgovor [ščc] pak, koji valja pretpostaviti na granici prefiksa $r a z-, i z$ - i korijena koji započinje s $\check{c}$ (usp. HCSL 2014: 67), u malobrojnim je primjerima u obama zbornicima bilježen

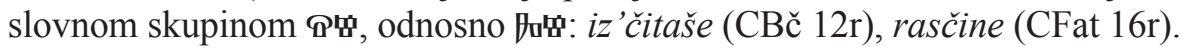

${ }^{12}$ U gotovo svim primjerima koji se navode u ovome odjeljku izgovor [ć], odnosno [šć] rezultat je jotacije. Iznimke su prilično rijetke. Među navedenim primjerima izdvajamo šĉap, šcit i $o s ̌ c e$, koji su nastali prvom palatalizacijom velara $k$ ispred kojega se nalazio suglasnik $s$. Za šćap GLUHAK (1993: 613-614) kaže da je psl. *ščapr postalo od pie. *skēpos (usp. također SKOK 1973: 412). Za ošĉe MATASOVIĆ i dr. (2016: 409) kažu da je postalo od psl. *eščè, dok je psl. riječ mogla postati od pie. ${ }^{*} h_{1} e s k^{(w)} e$. Konačno, šcit je, prema SKOKU (1973: 415), postalo od pie. korijena *skei- 'rezati' proširena s -to (usp. također GLUHAK 1993: 614; HOLZER 2011: 155). Nakon prve palatalizacije velara $k$ regresivnom je asimilacijom $s$ ispred $\check{c}$ prešlo u $\check{s}$.

13 Više o tome v. u odjeljku 4.14.4. 


\subsection{Znakovi za bilježenje jerova}

Od četiriju znakova koji su se u glagoljskim tekstovima pisanim hrvatskim crkvenoslavenskim jezikom rabili za obilježavanje jerova (咁, '由, I, ' (usp. HCSL 2014: 67) u Fatevićevu zborniku pojavljuje se samo štapić (I). I on se, međutim, u zborniku ostvaruje sporadično, obično (premda i tu neredovito) u skraćenicama $b(0 g) b(C F a t 8 \mathrm{r}, 10 \mathrm{v}, 14 \mathrm{~d}, 18 \mathrm{v}, 22 \mathrm{v}, 27 \mathrm{r}, 34 \mathrm{r}, 38 \mathrm{v}, 40 \mathrm{v}, 74 \mathrm{r}$ itd.) i g(ospodi)nb (CFat 7v, 8r, 14r, 15v, 16v, 18r, 18v, 25r, 27r, 34r, 38v, 68v, $74 \mathrm{r}$ itd.). Na kraju ostalih riječi štapić se bilježi vrlo rijetko i nesustavno, kako se vidi u (21). Upotreba štapića nije zabilježena unutar riječi. Jasno je, dakle, da jer (a) u Fatevićevu zborniku nema nikakvu glasovnu vrijednost i da se u njemu štapić pojavljuje samo kao ostatak pisarske tradicije:

(21) bo (go)mb (CFat 12r, 26v, 31r), amenb (CFat 1r), č (lo)vekb (CFat 15v), is $(u) h(r s t) b$ (CFat 14r, 75r, 75v), isusb (CFat 21r, 73r, 74r, 79r).

U Berčićevu se zborniku od spomenutih znakova za poluglas ostvaruju štapić (I) i apostrof ( $\left(^{r}\right)$, s tim da se apostrof upotrebljava znatno češće. Štapić u većini slučajeva dolazi na kraju riječi, premda se i u tome položaju nešto češće ostvaruje apostrof, dok se unutar riječi upotrebljava samo iznimno, obično u skraćenicama neposredno iza ispuštenoga dijela riječi ili između dvaju ispuštenih dijelova (22). Apostrof se obično upotrebljava na mjestu slaboga poluglasa, s tim da u tome položaju nerijetko izostaje, kako se vidi u (23). Zabilježeni su, međutim, i suprotni primjeri, tj. slučajevi u kojima se apostrof bilježi na mjestima na kojima poluglas nikada nije bio (24), kao i primjeri bilježenja znaka za poluglas (bilo apostrofa bilo štapića) na mjestu izvornoga $a$, npr. u prijedlozima $n a$ i $n a d b$, akuzativnom imeničkom obliku materb, u imenici salbtirb, u prefiksu raz-itd. (25). ${ }^{14}$ Sve to pokazuje da se znakovi za poluglas i u Berčićevu zborniku pojavljuju samo kao ostatci pisarske tradicije, odnosno da nemaju nikakvu glasovnu vrijednost:

(22) $h(r) b(s t) e ̂ n e ~(C B c ̌ ~ 6 v, 9 r), ~ h(r) b(s t) \hat{e}(n o) m$ ' (CBč 15r), h(rbst)bêne (CBč 15v)

(23) otca (CBč 4v), mnô̂ (CBč 4v), sudcemb (CBč 46v), konca (CBč $46 \mathrm{v})$, zlo $(\mathrm{CBč} 64 \mathrm{v})$

(24) milos 'ti (CBč 18r), budet'e (CBč 20r), k'rivo (CBč 20v), s'tado (CBč $21 \mathrm{v})$, v'rime (CBč 32v), bêžat'i (CBč 40v), miš'laše (CBč 45r), s'voihs (CBट̌ 47r)

(25) an'drêi že vidiv' g(ospod)a pade n' z(eml)i (CBč 37v); poide nь goru visoku (CBč 62v); ace p(o)ps piv' mašu tere bljue $\cdot \tilde{v} \cdot(=3)$ sblt(i)re · $\tilde{v}^{\prime}(=3)$

${ }^{14}$ Bilježenje znaka za poluglas na mjestu izvornoga $a$ potvrđeno je i u drugim hrvatskoglagoljskim tekstovima, uključujući i one liturgijskoga karaktera. Usp. MIHALJEVIĆ 2015: 537. 
$m(a)$ še poi (CBč 49v); da bimb vidil' mês to ono g'di si se rodil' mster' bim 'ti pogubil' (CBč 63v); imihb vlastb nьd' tobomb (CBč $65 \mathrm{v})$; ako hoĉb rbzumiti ovu ričb Is(u)h(rbstov)u $\cdot$ učite se ot m(e)ne (CBč 53r); i togo r(a)di rız'mis'li (CBč 53r).

U hrvatskoglagoljskim tekstovima iz 12. st., kao i u dijelu tekstova iz 13. st. znakovi za poluglas obvezno su se upotrebljavali uz slogotvorne sonante $r$ i $l$, a kasnije su uz takve primjere supostojali i oni u kojima slogotvornost sonanata $r$ i $l$ nije bila označena ni na koji način (usp. DAMJANOVIĆ 2008: 54; HCSL 2014: 69). U Berčićevu se zborniku podjednako često ostvaruju primjeri sa znakom za jer (redovito apostrof) uz slogotvorno $r$ i primjeri bez popratnoga znaka, $\mathrm{s}$ tim da se kod prvih znak za jer mnogo češce ostvaruje iza slogotvornoga $r$ (26). Uz slogotvorno se $l$ pak u većini primjera bilježi popratni apostrof, i to ponovno češće iza nego ispred sonanta, premda ima i primjera bez ikakva popratnoga znaka (27). ${ }^{15}$ U Fatevićevu zborniku uz slogotvorno se $r$ nikada ne bilježi štapić, a isto vrijedi i za jedini primjer u kojem je očuvano slogotvorno $l(28)$ :

(26) $m r^{\prime} t v a(\mathrm{CBč} \mathrm{4v),} \mathrm{m'rtvu} \mathrm{(CBč} \mathrm{38v),} \mathrm{mrtvi} \mathrm{(CBč} \mathrm{56r)}$

(27) sl'nce (CBč 16r), s'ln'ce (CBč 17v), sln'ce (CBč 13r)

(28) mrmnati (CFat 33r), krv (CFat 72v), vrtal (CFat 72v), vdlbena (CFat $34 v)$.

U Berčićevu zborniku, kao i u mnogim drugim hrvatskoglagoljskim tekstovima, štapić i apostrof nerijetko se rabe i $» k a o$ indikatori jotacije i glasa $[j]$ između suglasnika i nekih znakova za samoglasnike« (HCSL 2014: 70). Znak za poluglas, i to redovito apostrof, rabi se onda kada iza suglasnika dolazi slovo B s glasovnom vrijednošću [ja] (d'êvli CBč 55r, v'p 'êše CBč 24r, kr'st'ênb CBč 66v, brat'ê CBč 67r). U istome je položaju štapić zabilježen svega neko-

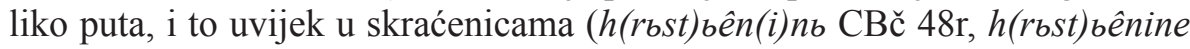
CBč 59r, $h(r b s t) b e ̂ n$ ski CBč 59v), što po svemu sudeći nije slučajno, jer je apostrof na istome mjestu zabilježen samo jednom: $h(r)$ '(st) 'êne (CBč 27r). U istoj se službi apostrof ostvaruje u različitim padežnim oblicima imenica na je (29); u pridjevima na -ji (30); u oblicima glagola biti 'tući' i vapiti i njihovih izvedenica (31) (usp. HCSL 2014: 70):

(29) govoren'e (CBč 9v), počten'emb (CBč 14r), žit'e (CBč 32r), v'spomenut'e (CBč 55r), stan'e (CBč 64v)

(30) bož'i (CBč 28v), vraž'i (CBč 40r), div'i (CBč 45v), div'e (CBč 56r)

\footnotetext{
$\overline{{ }^{15} \mathrm{O} \text { slogotvornom } r}$ i slogotvornom $l \mathrm{u}$ obama zbornicima više v. u potpoglavljima 4.8. i 4.9.
} 
(31) prib'eno (CBč 17r), b'eno (CBč 20v), raz'b'enu (CBč 38v), v'zvap'et' (CBč 16r, 21r).

\subsection{Slovo B}

Slovo B u Fatevićevu zborniku ima isključivo glasovnu vrijednost [ja], dok se u Berčićevu zborniku, osim s tom glasovnom vrijednošću, ostvaruje i na mjestu praslavenskoga jata. Za razliku od stanja u hrvatskoglagoljskim tekstovima liturgijskoga sadržaja u kojima se slovo B s glasovnom vrijednošću [ja] pojavljivalo samo na početku riječi i iza znakova za samoglasnike (usp. HCSL 2014: 70), u Berčićevu i, osobito, Fatevićevu zborniku ono može doći i iza znakova za suglasnike, kao u (32):

(32) vapêhu (CBč 18r), dêv(a)lı (CBč 62r); bratê (CFat 4v), vapêše (CFat 21r, 21v), dêvla (CFat 62v).

Na sam izgovor [ja] upućuju barem dvije činjenice: 1) u Berčićevu zborniku sporadična, a u Fatevićevu zborniku razmjerno česta pojavljivanja slovnih skupina IPP umjesto $\mathrm{B}$, kao u (33); 2) pojavljivanje slova $\mathrm{B}$ na mjestu praslavenskoga slijeda $* d j a$, kao u (34):

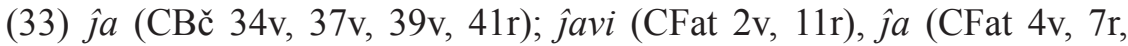
42v, 44r, 57v), ${ }^{16} \hat{j}$ ardana (CFat 15r), božja (CFat 15v), jazikom (CFat 16r), jati (CFat 24r), isaija (CFat 27r), prijatel (CFat 58r), jakosĉu (CFat 62v), vapjaše (CFat 64v)

(34) prohoêše (CBč 9r), viêhu (CBč 28v), viêše (CBč 60r), hoêhomo (CBč 74r); prihaê (CFat 2r), prohoêse (CFat 10r), pohaêla (CFat 20r), viêhu (CFat 20v, 24r), prihoêse (CFat 24r), sprovoêhu (CFat 24r), čuêhu (CFat 24v), žaên (CFat 29r).

\subsection{Slovo 四}

Slovo [l u Berčićevu i Fatevićevu zborniku ima glasovnu vrijednost [ju]. Na takav izgovor upućuje njegovo ostvarivanje na mjestu praslavenskoga slijeda $* d j u$, kao u (36), te činjenica da se kao označitelj palatalnosti nerijetko ostvaruje iza slova 由t i r, kao u (36). Ni u jednome ni u drugome zborniku nisu zabilježeni primjeri zamjenjivanja slova ఐl dvoslovom IPY.

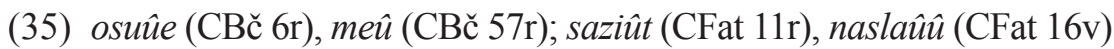

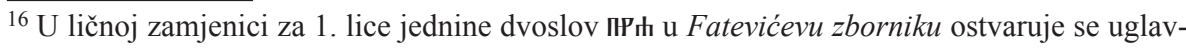
nom dosljedno. Tek je nekoliko potvrda bilježenja te zamjenice s pomoću slova B (CFat 21r, $34 \mathrm{r}, 62 \mathrm{v}, 67 \mathrm{r})$. 
(36) lûtimi (CBč 9v), m(i)l(o)stinû (CBč 21v); zlûblena (CFat 1v), kralû (CFat 34r).

\subsection{Udvajanje slova}

Udvajanje slova (geminacija), inače česta pojava u hrvatskoglagoljskim tekstovima (usp. MIHALJEVIĆ 2008: 43; HCSL 2014: 72), u Fatevićevu je zborniku potvrđeno prilično rijetko. Pronađeno je svega pet primjera, i to tri u stranim (37) i dva u domaćim riječima (38), s tim da u potonjima jedan primjer udvajanja nalazimo na granici korijena i sufiksa, a drugi na granici prefiksa i korijena. I u (37) i u (38) udvajanje je samo grafijska pojava i ne pretpostavlja udvojeni izgovor suglasnika. Kod stranih se riječi to dobro može vidjeti na primjeru imena anna, koje je u tekstu više puta zapisano jednostrukim (neudvojenim) suglasnikom: anu (CFat 23v, 24r, 24v). Isto vrijedi i za domaće riječi. Naime, uz primjer oddilili, u Fatevićevu zborniku nalazimo i primjere odiliši (CFat 1r), odilil (CFat $4 \mathrm{v}$ ), dakle bez udvajanja suglasnika. Još su bolji dokaz neizgovaranja udvojenih suglasnika primjeri tipa bezakoniê (CFat 11r), bezakonici (CFat 11r), bezakonie (CFat 11r), bezakono (CFat 26v), rasuene (CFat $15 \mathrm{v})$, koji su dosljedno pisani fonetski.

(37) anna (CFat 5v), annin (CFat 73r), maggoha (CFat 44v-45r)

(38) nepristanno (CFat 7r), oddilili (CFat 73r).

U Berčićevu je zborniku mnogo više primjera bilježenja udvojenih suglasnika nego u Fatevićevu zborniku. Udvojeni se suglasnici rjeđe ostvaruju u stranim riječima, kao u (39), u kojima po svoj prilici predstavljaju samo grafijsku pojavu nastalu preuzimanjem stranoga načina pisanja i ne odražavaju stvarni udvojeni izgovor suglasnika (usp. MIHALJEVIĆ 2008: 45). Na takav zaključak upućuje stanje u drugim hrvatskoglagoljskim tekstovima u kojima se neke od navedenih riječi ponekad pišu bez udvajanja suglasnika (usp. MIHALJEVIĆ 2008: 45; HCSL 2014: 73), ali i primjer muro (CBč 23r) iz Berčićeva zbornika, koji je jednom pisan s udvajanjem, a jednom bez udvajanja.

(39) man'na (CBč 18v), ên'na (CBč 19r), anna (CBč 52r), an'na (CBč 52r), an'nina (CBč 52v), os (a)n'na (CBč 17v), mur'ro (CBč 24v), sar'ra (CBč 43r).

Češće se udvojeni suglasnici u Berčićevu zborniku bilježe u domaćim riječima u kojima su mogli postati na dva načina: ulančavanjem i jednačenjem (usp. LAHIRI; HANKAMER 1988; prema MIHALJEVIĆ 2008: 44). Udvojeni suglasnici nastali ulančavanjem potvrđeni su gotovo isključivo na granici korijena i sufiksa, kao u (40), a među njima se uglavnom redovito bilježi apo- 
strof. S druge strane, primjeri udvajanja na granici prefiksa i korijena, nastali bilo ulančavanjem bilo jednačenjem, prilično su rijetki (41):

(40) mek'ke (CBč 74r), v'sedan'ni (CBč 5v, 7r), istin'nago (CBč 7r, 25r), kamen'nu (CBč 10v), bezakon'no (CBč 18v, 20v, 21r), zakon'nikb (CBč 17v), nepovin'nu (CBč 18r), stran'nimb (CBč 21v), stran'nago (CBč 23r), stran'nêi (CBč 23v), pustin'noi (CBč 23v), pus 'tin'nolûb'na (CBč 24r), okan'ni (CBč 32v), okan'na (CBč 42r), plemen'nika (CBč 33r), inoplemen'nikov' (CBč 70v), premen 'nu (CBč 35v), ogan'na (CBč 43v), gostin'nikb (CBč 55v), iskr'n'nago (CBč 73v), vrêmen'no (CBč 73v)

(41) od'dâu (CBč 19v), ottolê (CBč 3v, 23r), ot'tudu (CBč 34v), ras 'sr'di (CBč 8r), rassikaûci (CBč 16v), is sah'nuše (CBč 32r), ras sipa (CBč $57 \mathrm{v})$.

Ni na granici prefiksa i korijena te korijena i sufiksa bilježenje udvojenih suglasnika vjerojatno ne pretpostavlja udvojeni izgovor suglasnika, nego samo ukazuje na težnju pisara da očuva identitet prefiksa odnosno sufiksa (usp. MIHALJEVIĆ 2008: 49). Potvrđuju to brojni primjeri nebilježenja udvojenih suglasnika na mjestima na kojima bi se oni mogli očekivati (42):

(42) ras'rdi (CBč 9v, 76v), rastavit' (CBč 56r), otegnuti (CBč 65v), iskr'nemu (CBč 6r), iskrnemu (CBč 7v), iskrnega (CBč 7v), iskr 'nihb (CBč 54v), bezakoniê (CBč 42v).

U domaćim je riječima u Berčićevu zborniku potvrđeno i nekoliko primjera udvajanja suglasnika u korijenu. Radi se redom o prefigiranim oblicima glagola žeći »koji su izvedeni od prijevojnoga stupnja korijena $\check{z} g-«$ (HCSL 2014: 75). Udvojeni se suglasnici u tome položaju u hrvatskoglagoljskim tekstovima bilježe znatno dosljednije negoli u drugim dosad spomenutim položajima, vjerojatno zato što bi ispuštanjem jednoga $z$ korijen za čitatelja postao neraspoznatljiv (usp. MIHALJEVIĆ 2008: 52), pa se stoga tu »s najvećom vjerojatnošću može pretpostaviti udvojeno izgovaranje suglasnika $\check{z} \lll$ (MIHALJEVIĆ 2008: 53; HCSL 2014: 76). Među udvojenim se suglasnicima, kako se vidi iz primjera (43), nerijetko nalazi apostrof, a zabilježeni su u hrvatskoglagoljskim tekstovima i primjeri analoškoga umetanja samoglasnika $e$ prema punom korijenu žeg- (usp. MIHALJEVIĆ 2008: 52). ${ }^{17}$

(43) požže (CBč 48r), zaž že (CBč 50r), pož ’̌̌u (CBč 64r).

\footnotetext{
${ }^{17}$ Takve smo oblike, primjerice, pronašli u Klimantovićevu zborniku I.: ožežet' (RitKlim 229); raz'žeži (RitKlim 281).
} 


\section{GLASOVNE PROMJENE}

\subsection{Odrazjata}

Bilježenje grafema $\mathbb{B}$ na mjestu praslavenskoga jata u velikoj većini hrvatskoglagoljskih tekstova nastalih u 15. st. ili ranije, dakle po prilici do razdoblja kada je nastao stariji od rukopisa kojima se ovdje bavimo, vrlo je pravilno (usp. MIHALJEVIĆ 1991: 61; S̆IMIĆ 2007: 254; DAMJANOVIĆ 2008: 60) pa stoga istraživači fonem /ě/ pretpostavljaju kao sastavni dio glasovnoga sustava hrvatskoga crkvenoslavenskog jezika (usp. MIHALJEVIĆ 1991: 62; HCSL 2014: 71). Znakovito je, međutim, da su već u nekim misalima i brevijarima iz 15. st., dakle u tekstovima najvišega ceremonijalnog karaktera (usp. CORIN 1993) po kojima se određuje norma hrvatskoga crkvenoslavenskog jezika, vrlo česte ikavske i(li) ekavske zamjene jata. ${ }^{18}$ Stoga je jasno i očekivano da takvih zamjena ima i u zbornicima neliturgijskoga štiva. Ivan Kosić, primjerice, ističe da je u Ivančićevu zborniku, jednom od najstarijih hrvatskoglagoljskih neliturgijskih zbornika, koji je po svoj prilici nastao na razmeđu 14. i 15. st., »uz dobro sačuvano $\hat{e}$ doneseno i mnogo primjera u kojima se jat $\mathrm{u}$ istim riječima reflektira uglavnom kao $i$, ali i kao e« (KOSIĆ 2010: 9). Ekavski i ikavski odrazi jata česti su i u Korizmenjaku Kolunićeva zbornika, s tim da je ikavskih korijena ipak više (DAMJANOVIĆ 2008: 254-265), a brojni ekavizmi potvrđeni su i u raznim tekstovima Žgombićeva zbornika $^{19}$ (usp. MILČETIĆ 1902: 270; GRABAR 1967: 121) te u Djelima Andrije i Mateja u gradu ljudoždera u Tkonskome zborniku (usp. GRABAR 1967: 168).

U Fatevićevu zborniku na mjestu praslavenskoga jata potvrđene su isključivo njegove ikavske i ekavske zamjene, dok slovo \& na tome mjestu nije zabilježeno niti jednom. U Berčićevu zborniku pak na mjestu praslavenskoga jata u mnogim primjerima dolazi upravo slovo B, no i u njemu prevladavaju primjeri s ikavskim ili ekavskim odrazom jata, kojih je po prilici dvostruko više u odnosu na primjere u kojima se bilježi tradicionalni grafem za jat.

Zanimljivo je promotriti distribuciju ikavskih i ekavskih zamjena jata. Oba su kodeksa nastala na zadarskome području pa se u njima očekuje ikavskoekavska zamjena jata, i to po pravilu koje su u trećem desetljeću 20. st. ustanovili Luka Jakubinski i Karl H. Meyer (usp. LISAC 2009: 96). To bi značilo

\footnotetext{
18 Više tome v. u MIHALJEVIĆ 1991: 58-61.

19 ŠTEFANIĆ (1970: 40) naglašava da u čitavome zborniku »vlada ikavsko-ekavski refleks s prevagom ekavskog«.
} 
da se ekavski odraz očekuje u položajima u kojima je jat stajao pred dentalima $d, t, s, z, n, l$ ili $r$ za kojima nije slijedio prednji samoglasnik, dok se u svim ostalim položajima očekuje ikavski odraz jata (usp. LISAC 2009: 96-97). Donoseći najvažnije obavijesti o Fatevićevu zborniku, Vjekoslav Štefanić istaknuo je da su u tome zborniku »brojniji (...) ikavizmi, ali ima mnogo i ekavizama« (ŠTEFANIĆ 1970: 57). Ta prosudba, premda točna, ipak nam ne govori mnogo o distribuciji ikavskih i ekavskih odraza jata jer ne uzima u obzir fonološku okolinu u kojoj se ti odrazi ostvaruju. Teoretski je, naime, moguće da je u zborničkim tekstovima ikavskih odraza više zbog učestalosti pojavljivanja oblika s korijenom u kojem se jat dosljedno odrazio ikavski, a stvarno je stanje možebitno takvo da je veći broj korijena u kojima je odraz jata ekavski. ${ }^{20}$ Zanimljiviji su nam stoga rezultati i obradba odraza jata koje je analizirajući tekst o djelima Andrije i Mateja u gradu ljudoždera u Berčićevu zborniku (CBč 34r-41v) donijela Biserka GRABAR (1967: 127-136). Autorica, naime, u tome radu izdvaja 34 korijena u kojima se po etimologiji nalazio jat. Uz svaki korijen donosi sve primjere potvrđene $\mathrm{u}$ analiziranome tekstu te utvrđuje da je odraz jata »u 16 osnova odnosno korijena ikavski (človêk-, dêt-, gnêv-, grêh-, lêp-, lêz-, mêd-, mêr-, plên-, rêč-, sêk-, slêp-, smê-, spê-, têh-, vrêm-), a samo u 5 korjenitih slogova ekavski (cêl-, pê-, svêt-, têles-, vêt-)« (GRABAR 1967: 138). ${ }^{21}$ Sličan postupak primjenjujemo i u ovome radu, s tom razlikom što u tablici koja slijedi donosimo oprimjerenja iz svih tekstova jednoga i drugoga zbornika. ${ }^{22}$

\begin{tabular}{|l|l|l|}
\hline \multicolumn{1}{|c|}{ Korijen } & \multicolumn{1}{|c|}{ CBč } & \multicolumn{1}{|c|}{ CFat } \\
\hline \multirow{5}{*}{ bêg- } & raz'bigoše (CBč 11r), biži (CBč & bižimo (CFat 7r, 15r), biže (CFat \\
& 26v, 38r), bižet'(CBč 40v), pobiže & 8v), bižet (CFat 15r), pobigoše (CFat \\
& (CBč 41r) II iz'beg'neši (CBč 10r), & 15r, 19r), pobigneš (CFat 17v), po- \\
& ubežati (CBč 35r), begaûce (CBč & bignuti (CFat 17v, 18r, 35v), pobiže \\
& 62v) \|l bêzat'i (CBč 40v), ubêg'li & (CFat 26v), pobigal (56v) \\
& (CBč 55r), pobêže (CBč 69r) & \\
\hline \multirow{2}{*}{ bêl- } & bêla (CBč 16r), bêli (CBč 31v), & beli (CFat 13v), bela (CFat 21v), \\
& bêlimi (CBč 73v) & belu (CFat 73v) \\
\hline
\end{tabular}

$\overline{{ }^{20}}$ Za obrnut slučaj u Korizmenjaku Kolunićeva zbornika v. DAMJANOVIĆ 2008: 273.

${ }^{21} \mathrm{U}$ ostalim se korijenima uz ikavski ili ekavski odraz ostvaruje i tradicionalni grafem za jat, a u trima se korijenima ostvaruje isključivo taj grafem (usp. GRABAR 1967: 138).

${ }^{22}$ Iz praktičnih razloga kod korijena koji su isključivo ikavski ili isključivo ekavski, odnosno kod korijena u kojima se uz isključivo ikavski ili isključivo ekavski odraz ostvaruju još samo primjeri s tradicionalnim grafemom za jat, ne donosimo sve pronađene potvrde. 


\begin{tabular}{|c|c|c|c|}
\hline \multicolumn{2}{|c|}{ Korijen } & CBč & \multirow[b]{2}{*}{\begin{tabular}{|l} 
CFat \\
besidu (CFat 61v, 77r), beside (CFat \\
$66 \mathrm{r}, 68 \mathrm{r}, 71 \mathrm{r}, 74 \mathrm{r}, 79 \mathrm{v}) \| l$ besed (CFat \\
$5 \mathrm{v})$, besedami $($ CFat $14 \mathrm{v}, 15 \mathrm{v}, 30 \mathrm{v})$ \\
besede $($ CFat $16 \mathrm{r}, 16 \mathrm{v}, 19 \mathrm{r}, 20 \mathrm{v}, 29 \mathrm{v}$, \\
30v, 32v, 35v, 39v, 71v, 75v), besedi \\
(CFat 20r)
\end{tabular}} \\
\hline \multicolumn{2}{|c|}{ besêd- } & 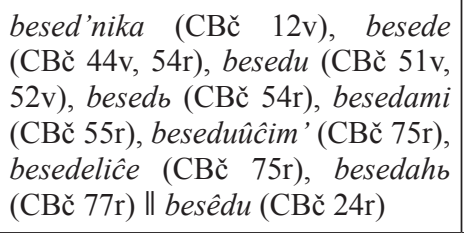 & \\
\hline \multicolumn{2}{|l|}{ bês- } & $\begin{array}{l}\text { bêsni (CBč 24v), bêsi (CBč 36r, } \\
\text { 37v, 40r) }\end{array}$ & besi (CFat 23v) \\
\hline \multicolumn{2}{|c|}{ brêm- } & obrêmeneni (CBč 73r) & $\begin{array}{l}\text { brimena (CFat 38r, 38v), brimen } \\
\text { (CFat 38v) }\end{array}$ \\
\hline \multirow{3}{*}{ cêl- } & 'cio' & cêla (CBč 3r) & $\begin{array}{l}\text { celostiû (CFat 1r), celom (CFat 2v), } \\
\text { cel (CFat 3r) }\end{array}$ \\
\hline & 'cijeljeti' & $\begin{array}{l}\text { is'celati (CBč 1v), iscêlêše (CBč } \\
24 \mathrm{v}) \text {, iscêliše (CBč 24v), cêlahu } \\
(\mathrm{CBč} 25 \mathrm{r}) \text {, is'cêli (CBč 32r), celaše } \\
(\mathrm{CBč} \mathrm{36v),} \mathrm{neiscelena}(\mathrm{CBč} 69 \mathrm{v}) \text {, }\end{array}$ & $\begin{array}{l}\text { iscelim }(\mathrm{CFat} 4 \mathrm{v}, 7 \mathrm{r}) \text {, celahu }(\mathrm{CFat} \\
\text { 23r), isceliti (CFat 23r) }\end{array}$ \\
\hline & 'cjelivati' & $\begin{array}{l}\text { celivaûtb (CBč } 3 \mathrm{v}) \text {, celuite (CBč } \\
\text { 13r), celuût' (CBč 14r), celivaše } \\
\text { (CBč 24r), celovas 'ta (CBč } 38 \mathrm{r}) \text {, } \\
\text { ob'celivaše (CBč } 70 \mathrm{v})\end{array}$ & $\begin{array}{l}\text { celunuši (CFat 21r), celuû (CFat } \\
72 \mathrm{v})\end{array}$ \\
\hline \multicolumn{2}{|c|}{ cên- } & $\begin{array}{l}\text { ucini (CBč 26v), s'ciniti (CBč } \\
\text { 26v) }\end{array}$ & mnogoceno (CFat 13v) \\
\hline \multicolumn{2}{|c|}{ crêkv- } & $\begin{array}{l}\text { crikveni }(\mathrm{CBč} 57 \mathrm{v}) \text {, crikveno }(\mathrm{CBč} \\
58 \mathrm{r}) \text {, crikvenoga (CBč } 58 \mathrm{r})\end{array}$ & $\begin{array}{l}\text { crikvu }(\mathrm{CFat} 1 \mathrm{v}, 52 \mathrm{v}, 53 \mathrm{v}) \text {, crikva } \\
(\mathrm{CFat} 2 \mathrm{r}, 14 \mathrm{v}, 15 \mathrm{v}, 70 \mathrm{v}, 75 \mathrm{r}, 75 \mathrm{v}, \\
78 \mathrm{r}) \text {, crikve }(\mathrm{CFat} 5 \mathrm{r}, 55 \mathrm{r}, 58 \mathrm{v}, 66 \mathrm{r}, \\
75 \mathrm{r}, 79 \mathrm{r}), \text { crikvenim }(\mathrm{CFat} 5 \mathrm{r}) \text {, crikvi } \\
(\mathrm{CFat} 15 \mathrm{r}, 19 \mathrm{v}, 45 \mathrm{r}, 53 \mathrm{v}, 66 \mathrm{v}, 70 \mathrm{r} \text {, } \\
74 \mathrm{r}) \text {, crikveni }(\mathrm{CFat} 30 \mathrm{r}) \text {, crikveno } \\
(\mathrm{CFat} 78 \mathrm{v})\end{array}$ \\
\hline \multicolumn{2}{|c|}{ cvêt- } & $\begin{array}{l}\text { c'vite (CBč 71v) \| cvet' (CBč 2v) \| } \\
\text { c'vêtb (CBč 33r), cvêtb (CBč 72r) }\end{array}$ & $\begin{array}{l}\text { cvit (CFat 3r), cvica (CFat 3r), } \\
\text { cvicem (CFat } 7 \mathrm{v}, 29 \mathrm{v}, 75 \mathrm{v}) \text {, cvice } \\
\text { (CFat } 27 \mathrm{v}) \text {, procvitati (CFat 16v) } \\
\text { cvetci }(\text { CFat } 1 \mathrm{r}) \text {, cvet (CFat } 3 \mathrm{r})\end{array}$ \\
\hline \multicolumn{2}{|c|}{ človêk- } & $\begin{array}{l}\text { človiče (CBč 25r, 71r), čllo)vik' } \\
\text { (CBč 36r), človici (CBč 45v) }\end{array}$ & 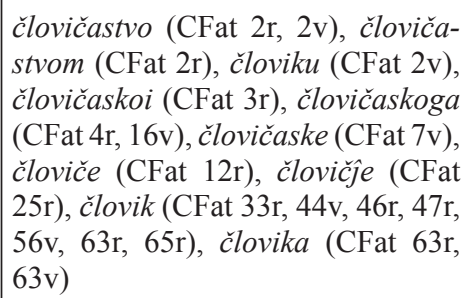 \\
\hline
\end{tabular}




\begin{tabular}{|c|c|c|}
\hline Korijen & CBč & CFat \\
\hline $\begin{array}{l}\text { dêl- } \\
\text { 'djelo' }\end{array}$ & $\begin{array}{l}\text { delaûĉu (CBč 2r), dela (CBč 4r, } \\
\text { 18v, 45r, 58r), delâ̂cihb (CBč 16r), } \\
\text { delaûcee (CBč 16v), delb (CBč 17v), } \\
\text { delati (CBč 32r), del' (CBč 36v), } \\
\text { delomb (CBč 51v), delateli (CBč } \\
\text { 55v), delaše (CBč 58r) II dêli (CBč } \\
\text { 1r, 1v), dêla (CBč 2r, 33v, 59r, 67v, } \\
72 \mathrm{v}, 76 \mathrm{r}) \text {, dêl'(CBč 4r, 6v, 72v, 74r, } \\
74 \mathrm{v}) \text {, dêlaûcihb (CBč 16r), dêlihb } \\
\text { (CBč 19v, 33r, 42v, 43r, 46r), } \\
\text { dêlom' (CBč 53r), dêlomb (CBč } \\
55 \mathrm{v}), \text { dêlateli (CBč 55v), dêlali } \\
\text { (CBč 58v), dêlaše (CBč 58v), dêlo } \\
\text { (CBč 58v, 72v), dêlala (CBč 59r), } \\
\text { dêli (CBč 60r, 68v), dêlaûcei (CBč } \\
75 \mathrm{v})\end{array}$ & $\begin{array}{l}\text { dila }(\mathrm{CFat} 16 \mathrm{v}, 22 \mathrm{r}, 48 \mathrm{v}, 49 \mathrm{r}, 62 \mathrm{v}) \text {, } \\
\text { dilo (CFat 17r, 25v, 26v, 63r, 67r, } \\
\text { 77r), dilovaniê (CFat 63v), dilov } \\
\text { (CFat 66v), dilovanie (CFat 70r) } \| \\
\text { delaûci (CFat 1v), delo (CFat 7v), } \\
\text { delati (CFat 10r, 23v), del (CFat } \\
\text { 11r, 14r, 30v), delih (CFat 16r), dela } \\
\text { (CFat 17r, 74r), delaet (CFat 77r) }\end{array}$ \\
\hline $\begin{array}{l}\text { dêl- } \\
\text { 'dio' }\end{array}$ & $\begin{array}{l}\text { raz'dilil' (CBč 2v), raz'dilimo } \\
\text { (CBč 39v), dilišš (CBč 27v), udili } \\
(\mathrm{CBč} \mathrm{68r)} \mathrm{\| |} \mathrm{raz'delahu}(\mathrm{CBč} \mathrm{34r)}\end{array}$ & $\begin{array}{l}\text { odiliši (CFat 1r), nerazdilenom } \\
\text { (CFat 1v), odilil (CFat 4v), razdiluûu } \\
\text { (CFat 16r), dilil (CFat 38r), razdili } \\
\text { (CFat 40r), dili (CFat 40v, 57v, 61v, } \\
\text { 64r, 66r), dil (CFat 41v), dila (CFat } \\
\text { 41v, 54r, 65r), diliti (CFat 46r, 50v, } \\
62 \mathrm{v}, 65 \mathrm{r}) \text {, dile (CFat 46r, 70v), dilu } \\
\text { (CFat 35v, 53r, 54r), dilivši (CFat } \\
\text { 57r), razdilue (CFat 59v), razdilena } \\
\text { (CFat 60r), dilili (CFat 60v), raz- } \\
\text { diliti (CFat 61v), razdilenu (CFat } \\
62 \mathrm{r}) \text {, dileniê (CFat 63r), dilnik (CFat } \\
\text { 66v), razdiliše (CFat 71v), oddilili } \\
(\mathrm{CFat} 73 \mathrm{r}) \| \text { razdelaû (CFat 2r), del } \\
(\mathrm{CFat} 12 \mathrm{r}, 35 \mathrm{v}, 41 \mathrm{v}), \text { deli (CFat 16r, } \\
\text { 25r), delu (CFat 31v, 32r, 32v, 33v, } \\
\text { 34r, 34v, 38r, 39r, 40v, 41v, 42v), } \\
\text { dela (CFat 39v, 41r) }\end{array}$ \\
\hline dêt- & $\begin{array}{l}\text { dit'ce (CBč } 16 \mathrm{r}) \text {, ditci (CBč } 16 \mathrm{r}) \text {, } \\
\text { dit'cu (CBč } 41 \mathrm{r}), \text { dit'ca }(\mathrm{CBčc} 41 \mathrm{r} \text {, } \\
65 \mathrm{r}) \text {, ditetu }(\mathrm{CBč} 37 \mathrm{v}, 41 \mathrm{r}) \text {, diteti } \\
(\mathrm{CBč} 39 \mathrm{r}, 41 \mathrm{r}) \text {, dite }(\mathrm{CBč} 41 \mathrm{v}, 48 \mathrm{r} \text {, } \\
50 \mathrm{v}, 51 \mathrm{r}, 56 \mathrm{v}, 59 \mathrm{v})\end{array}$ & $\begin{array}{l}\text { diticem (CFat 3v), ditinstva (CFat } \\
\text { 8r), ditica (CFat 10r), dite (CFat } \\
\text { 34r), ditic (42v) }\end{array}$ \\
\hline
\end{tabular}




\begin{tabular}{|c|c|c|}
\hline Korijen & CBč & CFat \\
\hline dêv- & $\begin{array}{l}\text { divice (CBč 16v, 18r, 76v), divicu } \\
\text { (CBč 19r), divici (CBč 48r, 49r, } \\
\text { 51r, 77r), divica (CBč 56v, 77r) } \| \\
\text { devo (CBč 4r), devici (CBč 19r), } \\
\text { deve (CBč 28v) II dêvô̂ (CBč 19r), } \\
\text { dêvom' (CBč 27r) }\end{array}$ & 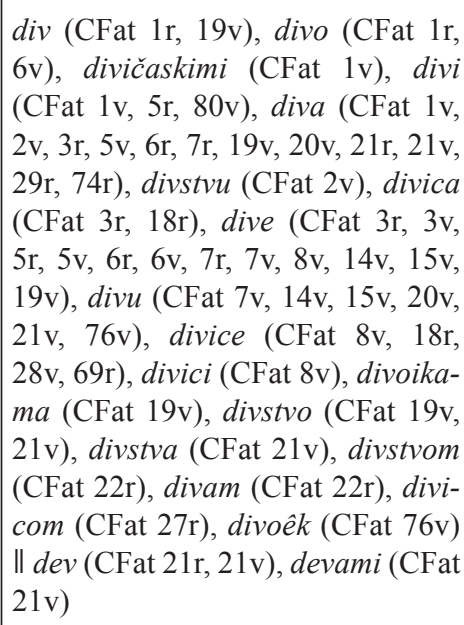 \\
\hline drêv- & $\begin{array}{l}\text { d'rivo (CBč 15r) \|l d'reve (CBč } \\
\text { 26r) II d'rêve (CBč 20v, 26r), d'rêvê } \\
\text { (CBč 20v), d'rêvo (CBč 28r), drêva } \\
\text { (CBč 64r) }\end{array}$ & $\begin{array}{l}\text { drivem (CFat 7v), driva (CFat 8r, } \\
10 \mathrm{v}, 11 \mathrm{v}, 12 \mathrm{r}, 12 \mathrm{v}, 13 \mathrm{v}, 28 \mathrm{r}, 77 \mathrm{r}) \text {, drivo } \\
(\mathrm{CFat} 11 \mathrm{v}, 12 \mathrm{v}, 13 \mathrm{v}, 14 \mathrm{r}, 16 \mathrm{r}, 29 \mathrm{r}, 71 \mathrm{v}, \\
72 \mathrm{r}, 73 \mathrm{v}) \text {, drivu (CFat 12r, 12v, 29r, } \\
75 \mathrm{v}) \text {, drivi (CFat 14r), driv (CFat 16r) }\end{array}$ \\
\hline êd- & 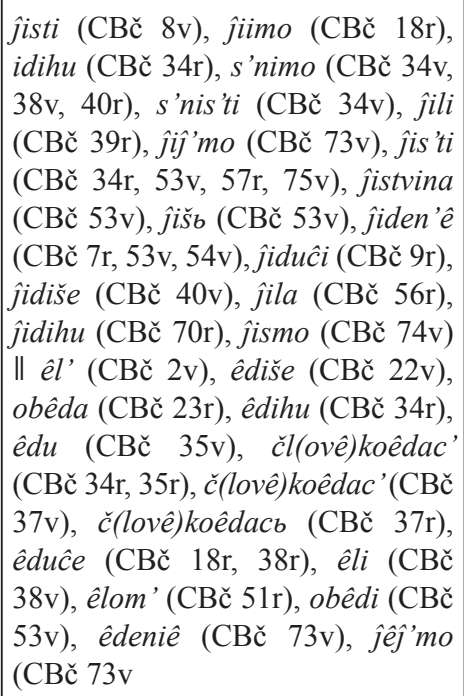 & 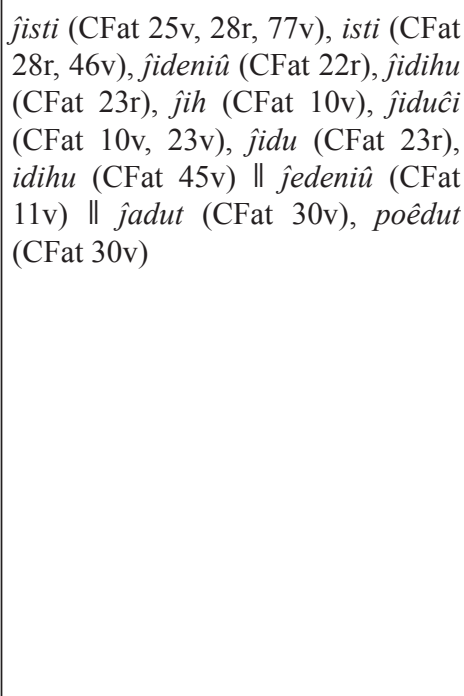 \\
\hline êzd- & jiz'di (CBč 52r), jiz'diti (CBč 56v) & - \\
\hline
\end{tabular}




\begin{tabular}{|c|c|c|}
\hline Korijen & CBč & CFat \\
\hline gnêv- & $\begin{array}{l}\text { raz'gnivaû (CBč 4v), raz'gniv' (CBč } \\
\text { 6r), g'nivaeš (CBč 13r), g'nivom, } \\
\text { (CBč 41r), gnivom' (CBč 43v), pro- } \\
\text { gnivaite (CBč 44v), g'niv' (CBč 44v), } \\
\text { g'niva (CBč 47r), g'nivb (CBč 69v), } \\
\text { g'nivanb (CBč 71v) Il gnêv'(CBč 27v), } \\
\text { gnêva (CBč 28r), gnêvomb (CBč 43v), } \\
\text { prognêvaeši (CBč 44v), gnêvi (CBč } \\
\text { 44v), g'nêvanb (CBč 54r), raz'gnêvav' } \\
\text { (CBč 62v), gnêvb (CBč 62v) }\end{array}$ & $\begin{array}{l}\text { gniva (CFat 2r), gniv (CFat 2v, 33r, } \\
\text { 33v, 37v, 65r), gnivom (CFat 31v) } \| \\
\text { gnev (CFat 2v, 33r, 36v) }\end{array}$ \\
\hline grêh- & 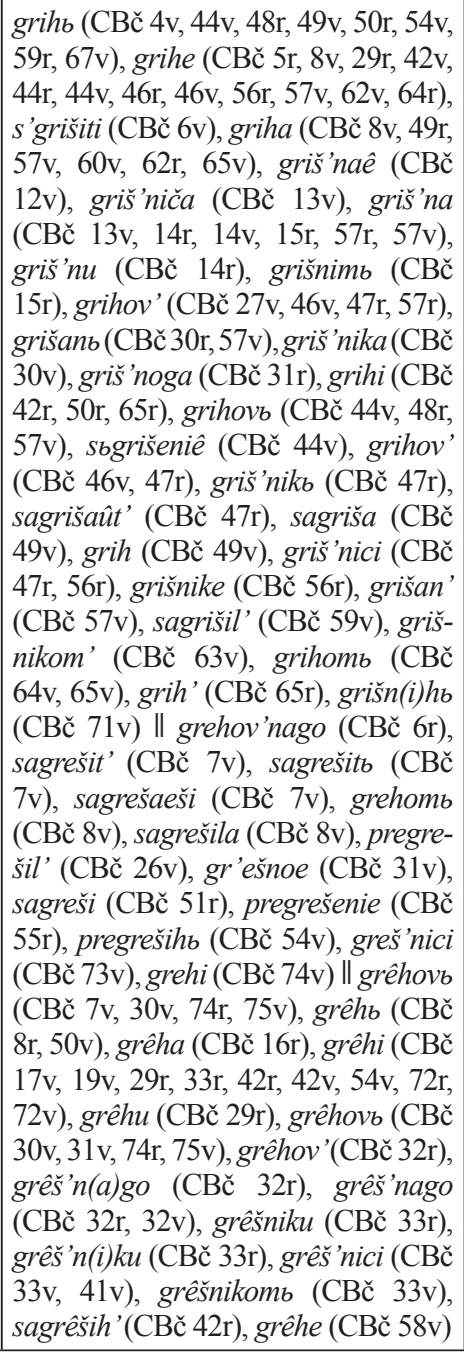 & $\begin{array}{l}\text { griha }(\mathrm{CFat} 1 \mathrm{v}, 37 \mathrm{v}, 43 \mathrm{r}, 46 \mathrm{r}) \text {, griho } \\
\text { (CFat 2r, 7r, 17r, 44v, 53r), grišni- } \\
\text { če (CFat 2v, 17v), grišnikom (CFat } \\
\text { 6r, 16r, 18v), grišnike (CFat 7r, 16r, } \\
\text { 21v), grisih (CFat 6r, 57r), grišnici } \\
\text { (CFat 6r, 15v, 16r, 17v, 18r, 18v), } \\
\text { zgriši (CFat 8r), grih (CFat 8r, 12v, } \\
\text { 26v, 31r, 31v, 37v, 38r, 39v, 43r, } \\
\text { 59r, 59v), grišnih (CFat 14v, 15r, } \\
\text { 74v), grišniko (CFat 16v, 18v), gri- } \\
\text { si (CFat 17v, 55v, 57v, 64r, 77v), } \\
\text { sagrišismo (CFat 17v), sagrišiše } \\
\text { (CFat 18r), grišnik (CFat 18r, 65v), } \\
\text { grišnika (CFat 18r), sagriši (CFat } \\
\text { 25r, 28r, 33v), sagriša (CFat 25r), } \\
\text { sagrišenem (CFat 28r), sagrišit } \\
\text { (CFat 28r), sagrišamo (CFat 29v, } \\
75 \mathrm{v}), \text { grihe (CFat 34r, 38r, 41r, 43r), } \\
\text { grihom (CFat 36v, 54r), grihi (CFat } \\
\text { 38r), grihov (CFat 44v), sagrišiti } \\
\text { (CFat 67v), grišna (CFat 74v), sa- } \\
\text { grišuemo (CFat 75r, 75v) }\end{array}$ \\
\hline
\end{tabular}




\begin{tabular}{|c|c|c|}
\hline Korijen & CBč & CFat \\
\hline hlêb- & $\begin{array}{l}\text { hliba (CBč 35r), hlibov' (CBč 36r) } \\
\text { II hlêbb (CBč 5v, 7r, 35v, 44r), hlêbi } \\
\text { (CBč 7r, 35v), hlêba (CBč 21v, 35r), } \\
\text { hlêb'(CBč 35v), h'lêba (CBč 35v), } \\
\text { hlêbi (CBč 35v), h'lêbb (CBč 45r) }\end{array}$ & hlib (CFat 2r, 29r), hliba (CFat 2r) \\
\hline kolên- & $\begin{array}{l}\text { kolina (CBč 72r) \| kolena (CBč } \\
\text { 20v) \|l kolêna }(\mathrm{CBč} 4 \mathrm{r}, 73 \mathrm{v}) \text {, kolênu } \\
(\mathrm{CBč} 14 \mathrm{v})\end{array}$ & $\begin{array}{l}\text { kolene (CFat 3r, 5v), kolena (CFat } \\
\text { 14v, 23r, 23v, 25v, 40v, 44v, 76r), } \\
\text { kolenov (CFat 45r), koleni (CFat } \\
\text { 70r), koleno (CFat 76r) }\end{array}$ \\
\hline krêp- & $\begin{array}{l}\text { krip'ko (CBč 14v), k'ripiti (CBč } \\
\text { 14v), k'ripet (CBč 14v) l krepla- } \\
\text { še (CBč 10r), krepakb (CBč 54r), } \\
\text { ukrepite (CBč 61v) l krêpostb (CBč } \\
\text { 1v), krêpos'ti (CBč 2r), krêposti } \\
\text { (CBč 9v), krêp'ko (CBč 2r, 20v), } \\
\text { krêpi (CBč 34v), krêpimo (CBč } \\
\text { 62v), krêpost' (CBč 67r), }\end{array}$ & $\begin{array}{l}\text { ukripiti (CFat 16r), kripostih (CFat } \\
\text { 22r), kriposti (CFat 22r, 45r, 60r, } \\
\text { 65v, 69r, 71r), kripost (CFat 59r, } \\
\text { 76v) }\end{array}$ \\
\hline krês- & $\begin{array}{l}\text { v'skrešati (CBč 1v), v’skrešenie } \\
\text { (CBč 33r), v'skrešaše (CBč 36v) ॥ } \\
\text { vskrêšenie (CBč 72v) }\end{array}$ & $\begin{array}{l}\text { vskrisiš (CFat 21r) II skresiti (CFat } \\
\text { 12r), vskresit (CFat 12r), iskrešenie } \\
\text { (CFat 13r), skrešenie (CFat 14r), } \\
\text { vskresil (CFat 27r) }\end{array}$ \\
\hline lêk- & $\begin{array}{l}\text { likara (CBč 51v), liča }(\mathrm{CBč} 51 \mathrm{v}) \text {, } \\
\text { ličil' (CBč 51v), likar'stva (CBč } \\
51 \mathrm{v})\end{array}$ & $\begin{array}{l}\text { likari (CFat 23r, 61r), likar (CFat } \\
\text { 23r, 23v), ličiti (CFat 29v), izliče } \\
\text { (CFat 29v), izličiti (CFat 75r) }\end{array}$ \\
\hline lên- & $\begin{array}{l}\text { linost' (CBč 47r) \|l leni (CBč 2v), } \\
\text { lenostb (CBč 62r) II lênim' (CBč } \\
\text { 18v), lênosti (CBč 32v), lênišs'(CBč } \\
\text { 54r), lênimb (CBč 75v) }\end{array}$ & linosĉu (CFat 28v) \\
\hline lêp- & 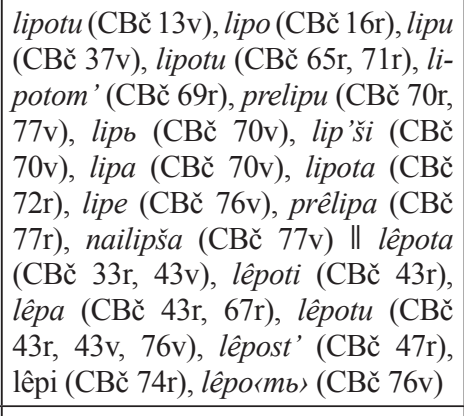 & $\begin{array}{l}\text { liposti (CFat 1v), lipla (CFat 3r), } \\
\text { liple (CFat 3r), lipli (CFat 7v), lipo- } \\
\text { sti (CFat 7v), lipote (CFat 20r, 26r), } \\
\text { lipotom (CFat 20v), liplega (CFat } \\
\text { 22v), lipu (CFat 41v), lipost (CFat } \\
\text { 60v), lipota (CFat 61r), lipim (CFat } \\
\text { 78r) }\end{array}$ \\
\hline lêt- & $\begin{array}{l}\text { lito (CBč 50v), liti (CBč 67r) \|l lêta } \\
\text { (CBč 56r) }\end{array}$ & $\begin{array}{l}\text { lit }(\mathrm{CFat} 43 \mathrm{v}, 80 \mathrm{v}) \| \text { let }(\mathrm{CFat} 1 \mathrm{v}, 3 \mathrm{v} \text {, } \\
10 \mathrm{r}, 11 \mathrm{r}, 13 \mathrm{r}, 26 \mathrm{r}, 31 \mathrm{r} 74 \mathrm{r}, 75 \mathrm{r}) \text {, leto } \\
(\mathrm{CFat} 2 \mathrm{r}, 5 \mathrm{r}, 5 \mathrm{v}, 21 \mathrm{v}) \text {, leta }(\mathrm{CFat} 2 \mathrm{r} \text {, } \\
\text { 16r, 20r), protuletna (CFat 6r), le- } \\
\text { tom (CFat 8v) }\end{array}$ \\
\hline
\end{tabular}




\begin{tabular}{|c|c|c|}
\hline Korijen & CBč & CFat \\
\hline lêv- & live (CBč 14r, 71v) & $\begin{array}{l}\text { livu }(\mathrm{CFat} 10 \mathrm{v}, 17 \mathrm{v}, 39 \mathrm{v}) \text {, livo }(\mathrm{CFat} \\
17 \mathrm{v}) \text {, liva }(\text { CFat 36r) }\end{array}$ \\
\hline -lêz- & $\begin{array}{l}\text { v'lizoše (CBč 11v), v'lizu (CBč } \\
\text { 35r), v'lize (CBč 37v), v'lizeši (CBč } \\
\text { 42r), iz'lizi (CBč 44v), iz'lize (CBč } \\
\text { 45r), vlizutb (CBč 45r), iz'lizen'û } \\
\text { (CBč 59r), slize (CBč 62v), vlizu } \\
\text { (CBč 63v), v'listi (CBč 63v) Il vleze } \\
\text { (CBč 23r) Il v'lêz' (CBč 22r), iz'lêze } \\
\text { (CBč 22r), iz'lêz (CBč 22r), v'lêz'šu } \\
\text { (CBč 22v), iz'lêzb (CBč 23r) }\end{array}$ & $\begin{array}{l}\text { vzlizeši (CFat 18v), izlize (CFat } \\
\text { 20v), izlizoše (CFat 20v), vlizoše } \\
\text { (CFat 32v), ulize (CFat 45v, 53v), } \\
\text { ulizli (CFat 52v), ulizoše (CFat } \\
53 \mathrm{v}) \text {, ulisti (CFat } 62 \mathrm{v}) \\
\end{array}$ \\
\hline mêd- & miden'(CBč 38v) & - \\
\hline mên- & $\begin{array}{l}\text { premini (CBč 38r) \| iz'meni (CBč } \\
\text { 34r), premen'nu (CBč 35r), preme- } \\
\text { ni (CBč 47r), iz'menue (CBč 71r) }\end{array}$ & $\begin{array}{l}\text { primini }(\mathrm{CFat} 25 \mathrm{v}), \text { preminimo } \\
(\mathrm{CFat} 30 \mathrm{r}) \text {, preminue (CFat 32v), } \\
\text { prominenie (CFat } 68 \mathrm{r}) \text {, priminite } \\
(\mathrm{CFat} 78 \mathrm{r})\end{array}$ \\
\hline mêr- & 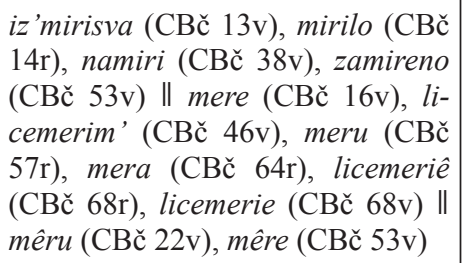 & $\begin{array}{l}\text { zamiriti (CFat 2r, 2v, 32r, 39r), za- } \\
\text { miri (CFat 3v, 31v, 33r, 33v, 34r, } \\
36 \mathrm{v}, 38 \mathrm{v}, 41 \mathrm{v}, 71 \mathrm{v}, 72 \mathrm{r}), \text { namiri } \\
(\mathrm{CFat} 25 \mathrm{v}), \text { zamiraite }(\mathrm{CFat} 25 \mathrm{v}) \text {, } \\
\text { mirilih }(\mathrm{CF} a \mathrm{t} 38 \mathrm{v})\end{array}$ \\
\hline mêsec- & $\begin{array}{l}\text { miseca (CBč 10v), misec' (CBč } \\
\text { 57r, 64r), misecb (CBč 64r) }\end{array}$ & $\begin{array}{l}\text { misec (CFat 2r, 13r, 16v, 17r, 17v, } \\
22 \mathrm{v}, 30 \mathrm{r}, 79 \mathrm{r}), \text { miseca (CFat 5r, 44r, } \\
80 \mathrm{v}), \text { misecom (CFat 7v), mise- } \\
\text { cu (CFat 9v, 14r, 15v, 16r), miseci } \\
\text { (CFat 31r, 77r) }\end{array}$ \\
\hline mêst- & 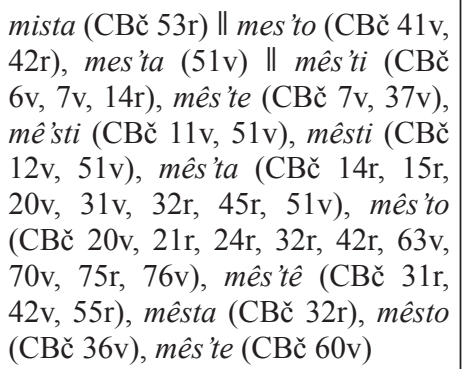 & $\begin{array}{l}\text { misto (CFat 24r, 24v, 49r, 50r, 51v, } \\
53 \mathrm{r}, 53 \mathrm{v}, 54 \mathrm{r}, 58 \mathrm{v}, 62 \mathrm{r}, 70 \mathrm{r}, 71 \mathrm{r}), \\
\text { mistu }(\mathrm{CFat} 49 \mathrm{r}, 49 \mathrm{v}, 52 \mathrm{v}, 53 \mathrm{v}, 58 \mathrm{v}, \\
68 \mathrm{v}, 70 \mathrm{r}), \text { mista }(\mathrm{CFat} 52 \mathrm{v}, 62 \mathrm{r}, 70 \mathrm{v}) \\
\| 1 \text { mesto }(\mathrm{CFat} 1 \mathrm{v}, 9 \mathrm{v}, 10 \mathrm{r}, 10 \mathrm{v}, 11 \mathrm{r} \text {, } \\
13 \mathrm{r}, 13 \mathrm{v}, 14 \mathrm{r}, 18 \mathrm{r}), \text { mestih }(\mathrm{CFat} 8 \mathrm{v}, \\
26 \mathrm{r}), \text { mesti (CFat } 14 \mathrm{r}, 17 \mathrm{v}, 48 \mathrm{r}, 54 \mathrm{v}, \\
76 \mathrm{r}), \text { mesta }(\mathrm{CFat} 20 \mathrm{r}), \text { mestu }(\mathrm{CFat} \\
46 \mathrm{r}, 70 \mathrm{v})\end{array}$ \\
\hline nevêst- & neves to (CBč 71v) & $\begin{array}{l}\text { nevestom (CFat 37r), nevesta (CFat } \\
79 \mathrm{r})\end{array}$ \\
\hline pêsn- & $\begin{array}{l}\text { pês'ni (CBč 18r, 19r, 19v, 20r), } \\
\text { pês'nb (CBč 19r), pêsni (CBč 20r), } \\
\text { pês(a)nb (CBč 53v) }\end{array}$ & $\begin{array}{l}\text { pesneh (CFat 1r, 7v, 22r), pesnike } \\
\text { (CFat 5r), pesni (CFat 20v) }\end{array}$ \\
\hline
\end{tabular}




\begin{tabular}{|c|c|c|}
\hline Korijen & CBč & CFat \\
\hline pênez- & $\begin{array}{l}\text { pinezb (CBč 26v), pinezi (CBč 55v, } \\
66 \mathrm{r})\end{array}$ & pinez (CFat 24v, 72v) \\
\hline pê(v)- & $\begin{array}{l}\text { v'spivaûci }(\mathrm{CBč} 10 \mathrm{v}) \| \text { peti (CBč } \\
13 \mathrm{v}, 34 \mathrm{v}) \| \text { pêl' (CBč 50r) }\end{array}$ & $\begin{array}{l}\text { vspevahu (CFat 1r), peti (CFat 1r, } \\
\text { 6r), petie (CFat 5r), pecee (CFat 5r), } \\
\text { peli (CFat 5r), petiem (CFat 20v), } \\
\text { prospevaše (CFat 22r) }\end{array}$ \\
\hline plên- & plinimo (CBč 38v) & poplinen (CFat 15r) \\
\hline prêd- & $\begin{array}{l}\text { prid' (CBč 22v) ॥ pred' (CBč 4r, } \\
4 \mathrm{v}, 5 \mathrm{r}, 8 \mathrm{r}, 9 \mathrm{r}, 9 \mathrm{v}, 14 \mathrm{r}, 14 \mathrm{v}, 15 \mathrm{r}, 16 \mathrm{r} \text {, } \\
17 \mathrm{r}, 17 \mathrm{v}, 18 \mathrm{r}, 20 \mathrm{r}, 20 \mathrm{v}, 21 \mathrm{v}, 23 \mathrm{r}, \\
28 \mathrm{r}, 28 \mathrm{v}, 26 \mathrm{v}, 27 \mathrm{r}, 33 \mathrm{v}, 36 \mathrm{r}, 36 \mathrm{v} \text {, } \\
40 \mathrm{r}, 45 \mathrm{v}, 46 \mathrm{v}, 52 \mathrm{r}, 52 \mathrm{v}, 54 \mathrm{r}, 57 \mathrm{v}, \\
58 \mathrm{r}, 61 \mathrm{v}, 63 \mathrm{v}, 66 \mathrm{r}, 71 \mathrm{r}, 72 \mathrm{v}, 73 \mathrm{r} \text {, } \\
76 \mathrm{r}) \text { pred (CBč 41r, 46r) \| prêd' } \\
\text { (CBč 23v, 30r, 31r, 72v) }\end{array}$ & $\begin{array}{l}\text { prid (CFat 6v, 8v, 9v, 11r, 11v, 12r, } \\
\text { 14r, 16r, 20r, 20v, 23v, 24r, 27r, 31r, } \\
\text { 33r, 37r, 40v, 42v, 65v, 73r, 76r) } \\
\text { pred (3r, 11r, 29v, 33r, 76r, 77r) }\end{array}$ \\
\hline rêč- & 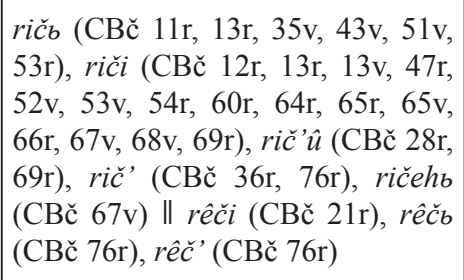 & $\begin{array}{l}\text { riči }(\mathrm{CFat} 2 \mathrm{r}, 2 \mathrm{v}, 3 \mathrm{v}, 5 \mathrm{r}, 33 \mathrm{r}) \text {, ričeh } \\
\text { (CFat 3r), rič (CFat } 13 \mathrm{r}, 22 \mathrm{v}, 42 \mathrm{v} \text {, } \\
78 \mathrm{v}, 79 \mathrm{r}) \text {, ričiu }(\text { CFat } 33 \mathrm{r}, 45 \mathrm{v}), \text { ri- } \\
\text { čami }(\mathrm{CFat} 65 \mathrm{v}, 66 \mathrm{v}) \\
\end{array}$ \\
\hline rêk- & rika (CBč 47v) \|| rêka (CBč 73r) & $\begin{array}{l}\text { rici }(\mathrm{CFat} 12 \mathrm{r}, 42 \mathrm{v}), \text { rike }(\mathrm{CFat} 12 \mathrm{v} \text {, } \\
42 \mathrm{v}) \text {, rika }(\mathrm{CFat} 12 \mathrm{v}, 42 \mathrm{v}), \text { riki } \\
(\mathrm{CFat} 27 \mathrm{v})\end{array}$ \\
\hline rêz- & $\begin{array}{l}\text { riži (CBč 53v) \|l urêza (CBč 24r), } \\
\text { obrêzati (CBč 43r), urêžut' (CBč } \\
73 r)\end{array}$ & $\begin{array}{l}\text { obrizana (CFat 2r), obrizane (CFat } \\
\text { 2r), obrizanie (CFat 2r), obrizani- } \\
\text { em (CFat 2r, 3v), obrizani (CFat } \\
\text { 2r), obrizal (CFat 3v), izrižu (CFat } \\
\text { 3v), obrizali (CFat 3v), obrizati } \\
\text { (CFat 4r), obriž (CFat 4r), obri- } \\
\text { zue (CFat 4r), obrizuemo (CFat } \\
\text { 4r), obrizanie (CFat } 4 \mathrm{r}) \| \text { obrezati } \\
\text { (CFat 4r) }\end{array}$ \\
\hline sêk- & $\begin{array}{l}\text { usiĉi (CBč 10r, 63v, 69r), otsiĉi } \\
\text { (CBč 45v), rassikaûci (CBč 16v), } \\
\text { usičemo (CBč 39v), otsiče (CBč } \\
45 \mathrm{v}) \text {, presiče (CBč 60r), usikoše } \\
\text { (CBč 69v) Il usêkut' (CBč 73r) }\end{array}$ & $\begin{array}{l}\text { posičeno (CFat 13v), posičeniem } \\
\text { (CFat } 37 \mathrm{v}) \text {, sikira (CFat } 77 \mathrm{r}) \text {, posi- } \\
\text { če }(\text { CFat } 77 \mathrm{r}, 77 \mathrm{v}, 79 \mathrm{r})\end{array}$ \\
\hline
\end{tabular}




\begin{tabular}{|c|c|c|}
\hline Korijen & CBč & CFat \\
\hline slêd- & $\begin{array}{l}\text { s'leda (CBč 9v), posled'ni (CBč 58v), } \\
\text { nasleduût' (CBč 61r), nasled'nica } \\
\text { (CBč 64v) II naslêduût' (CBč 4v), } \\
\text { slêdb (CBč 24v, 34r), napos'lêdakb } \\
\text { (CBč 31v), naslêdov(a)ti (CBč 75r) }\end{array}$ & $\begin{array}{l}\text { poslidni }(\mathrm{CFat} 12 \mathrm{r}, 35 \mathrm{v}) \text {, poslidnih } \\
\text { (CFat 13r), slidil (CFat 26v), poslid- } \\
\text { nem }(\mathrm{CFat} 42 \mathrm{v}), \text { naslidni }(\mathrm{CFat} 50 \mathrm{r}), \\
\text { naslidovaše (CFat 51r), naslidovati } \\
\text { (CFat 54r), poslidna (CFat 54r), } \\
\text { naiposlidnem (CFat 56v), naslidoval } \\
\text { (CFat 56v), naslidovata (CFat 63v), } \\
\text { naiposlidnega (CFat 63v), naslido- } \\
\text { vati (CFat 63r), naslidovanim (CFat } \\
\text { 63v) II sledu (CFat 26v), sleda (CFat } \\
\text { 26v), naslednici (CFat 31r) }\end{array}$ \\
\hline slêp- & $\begin{array}{l}\text { slipi (CBč 13r), slipe (CBč 36r), } \\
\text { slipihb (CBč 38r), o(s)lipiv'ši (CBč } \\
\text { 49v), slipa (CBč 59v, 65v), slips } \\
\text { (CBč 65v), oslipiše (CBč 70v) \|l } \\
\text { s'lêpie (CBč 1v), slêpi (CBč 24v) }\end{array}$ & $\begin{array}{l}\text { slip (CFat 6v, 26v), oslipla (CFat } \\
\text { 16v), oslipleni (CFat 16v), slipi } \\
\text { (CFat 18r, 60v), slipoga (CFat 21r), } \\
\text { slipih (CFat 29r) }\end{array}$ \\
\hline smêr- & 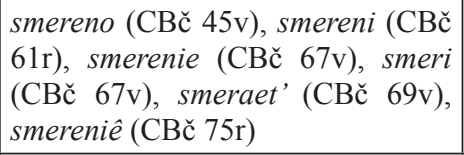 & smeren (CFat 72r) \\
\hline snêg- & sniga (CBč 45r) & snigu (CFat 55r) \\
\hline srêd- & $\begin{array}{l}\text { posred (CBč 78r) \|| posrêde (CBč } \\
24 \mathrm{v}, 39 \mathrm{v}) \text {, posrêdê (CBč 40v) }\end{array}$ & $\begin{array}{l}\text { nasrid }(\mathrm{CFat} 12 \mathrm{v}) \text {, sridi }(\mathrm{CFat} 49 \mathrm{v}) \text {, } \\
\text { posrid }(\mathrm{CFat} 60 \mathrm{v}) \text {, posridi }(\text { CFat } 60 \mathrm{v}) \\
\text { Il posrede }(\text { CFat } 2 \mathrm{v}, 11 \mathrm{v}, 20 \mathrm{v}, 40 \mathrm{v}, 74 \mathrm{v}) \text {, } \\
\text { sredu }(\text { CFat } 30 \mathrm{v}) \text {, posred }(\text { CFat } 71 \mathrm{v})\end{array}$ \\
\hline strêl- & - & strile (CFat 6v) \\
\hline svêd- & $\begin{array}{l}\text { svedekue }(\mathrm{CBč} 4 \mathrm{v}), \text { s'vedokb }(\mathrm{CBč} \\
68 \mathrm{v}) \text {, svedokuûcim' (CBč } 75 \mathrm{v}) \| \\
\text { svêdeč stvo }(\mathrm{CBč} 20 \mathrm{v}), \text { svêdočas 'tva } \\
(\mathrm{CBč} 21 \mathrm{v})\end{array}$ & $\begin{array}{l}\text { svidoci }(\mathrm{CFat} 16 \mathrm{v}, 66 \mathrm{r}), \text { svidočastvo } \\
\text { (CFat 16v, 17r, 46r, 66v), svidoči } \\
(\mathrm{CFat} 28 \mathrm{r}, 28 \mathrm{v}, 29 \mathrm{v}), \text { svidočahu }(\mathrm{CFat} \\
\text { 53v), svidokue }(\mathrm{CFat} 24 \mathrm{r}, 70 \mathrm{v})\end{array}$ \\
\hline $\begin{array}{l}\text { svêt- } \\
\text { 'svjetlo' }\end{array}$ & 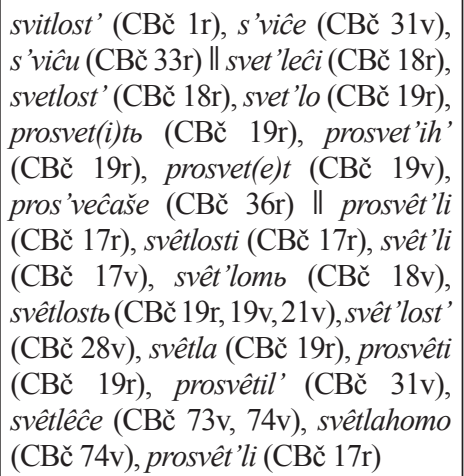 & 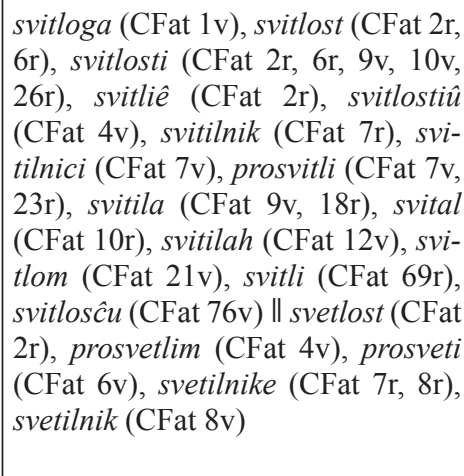 \\
\hline
\end{tabular}




\begin{tabular}{|c|c|c|}
\hline Korijen & CBč & CFat \\
\hline $\begin{array}{l}\text { svêt- } \\
\text { 'svijet' }\end{array}$ & svet'(CBč 2v), sveta (CBč 18r) & $\begin{array}{l}\text { svitu (CFat 4v, 5r, 15r, 15v, 16r, 20r, } \\
23 \mathrm{v}, 30 \mathrm{v}, 33 \mathrm{v}, 38 \mathrm{v}, 41 \mathrm{r}, 43 \mathrm{r}, 46 \mathrm{r}, \\
48 \mathrm{v}, 51 \mathrm{v}, 61 \mathrm{v}, 62 \mathrm{v}, 79 \mathrm{v}) \text {, svit (CFat } \\
4 \mathrm{v}, 33 \mathrm{v}, 44 \mathrm{r}, 45 \mathrm{r}, 45 \mathrm{v}, 50 \mathrm{r}, 50 \mathrm{v}, 61 \mathrm{v}, \\
64 \mathrm{r}, 70 \mathrm{r}), \text { svita }(\mathrm{CFat} 5 \mathrm{r}, 7 \mathrm{r}, 16 \mathrm{r}, 16 \mathrm{v}, \\
20 \mathrm{r}, 30 \mathrm{r}, 31 \mathrm{r}, 38 \mathrm{r}, 39 \mathrm{v}, 45 \mathrm{v}, 48 \mathrm{v}, 57 \mathrm{v}, \\
58 \mathrm{v}, 63 \mathrm{r}, 71 \mathrm{r}, 76 \mathrm{v}) \text {, svitovnih (CFat } \\
38 \mathrm{v})\end{array}$ \\
\hline têh- & $\begin{array}{l}\text { utišsiva (CBč 13r), utišen'e (CBč 15v), } \\
\text { utišen 'ê (CBč 19v), utišis 'te (CBč 20r), } \\
\text { tišiti (CBč 35v), utišent (CBč 54r), uti- } \\
\text { šitela (CBč 73v), utišitila (CBč 12v) \| } \\
\text { utešaût' (CBč 12v) \| utêšs (CBč 20r), } \\
\text { utêsiti (CBč 32v), utêšeniê (CBč 72v), } \\
\text { neutêšini (CBč 73v) }\end{array}$ & $\begin{array}{l}\text { utišenie (CFat 12v, 70v), utišiti } \\
\text { (CFat 16r, 18v), utišene (CFat 18r), } \\
\text { utihu (CFat 67v), utišena (CFat } \\
\text { 21v) }\end{array}$ \\
\hline têl- & 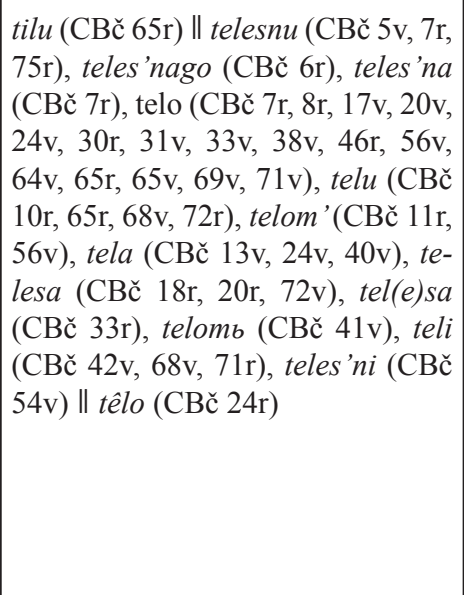 & 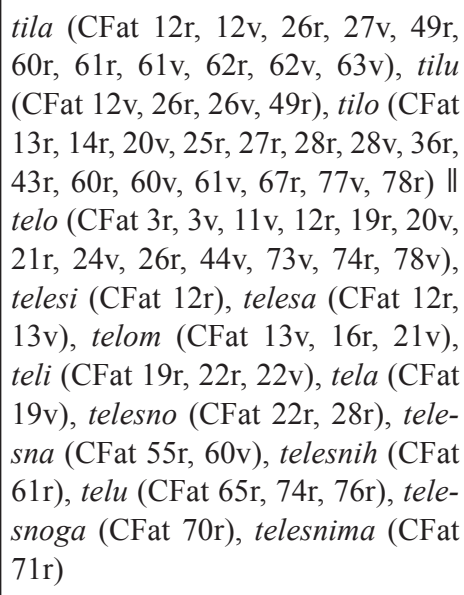 \\
\hline vêk- & 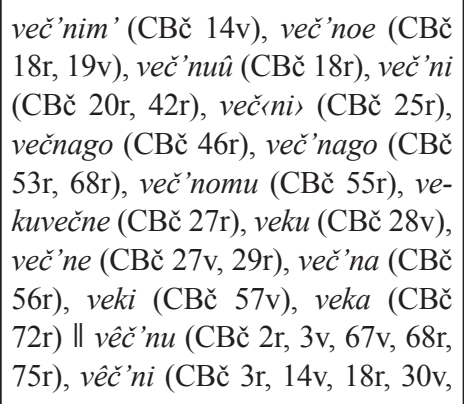 & $\begin{array}{l}\text { vika (CFat } 10 \mathrm{v}) \text {, vavični (CFat } \\
54 \mathrm{v}) \text {, vične }(\mathrm{CFat} 57 \mathrm{v}) \text {, vik (CFat } \\
62 \mathrm{r}) \text {, vike }(\mathrm{CFat} 75 \mathrm{r}) \| \text { veki }(\mathrm{CFat} 1 \mathrm{r} \text {, } \\
1 \mathrm{v}, 11 \mathrm{r}, 18 \mathrm{v}, 21 \mathrm{r}, 77 \mathrm{v}, 79 \mathrm{r}) \text {, večnom } \\
(\mathrm{CFat} 1 \mathrm{v}) \text {, doveka }(\mathrm{CFat} 1 \mathrm{v}) \text {, večni } \\
(\mathrm{CFat} 2 \mathrm{r}, 12 \mathrm{v}, 18 \mathrm{r}, 28 \mathrm{v}, 34 \mathrm{v}, 35 \mathrm{r} \text {, } \\
38 \mathrm{r}, 39 \mathrm{v}, 41 \mathrm{r}, 76 \mathrm{v}) \text {, večnago }(\mathrm{CF} a t \\
4 \mathrm{r}) \text {, večnim }(\mathrm{CFat} 4 \mathrm{v}, 26 \mathrm{v}) \text {, več- } \\
\text { noga }(\mathrm{CFat} 9 \mathrm{r}, 26 \mathrm{v}) \text {, večnoi }(\mathrm{CFat} \\
9 \mathrm{r}, 79 \mathrm{v}) \text {, večnaê }(\mathrm{CFat} 10 \mathrm{v}) \text {, vavek }\end{array}$ \\
\hline
\end{tabular}




\begin{tabular}{|c|c|c|}
\hline Korijen & CBč & CFat \\
\hline vêk- & 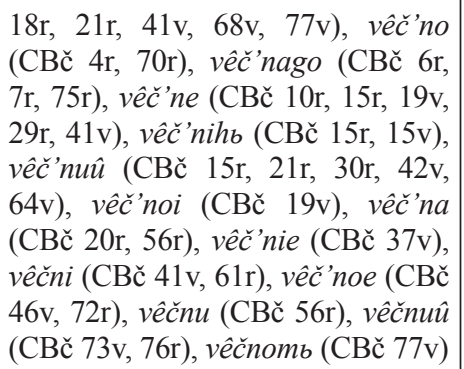 & $\begin{array}{l}\text { (CFat } 11 \mathrm{r}) \text {, veka (CFat } 11 \mathrm{r}) \text {, večnoe } \\
\text { (CFat } 15 \mathrm{r}) \text {, vek (CFat } 30 \mathrm{v}) \text {, večnu } \\
\text { (CFat } 77 \mathrm{r})\end{array}$ \\
\hline vênc- & 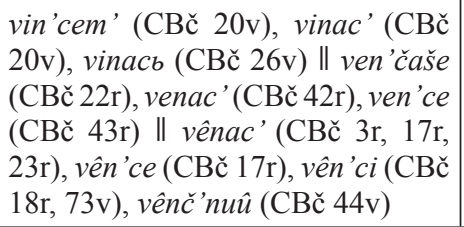 & $\begin{array}{l}\text { vencem }(\text { CFat } 24 \mathrm{v}, 29 \mathrm{v}) \text {, venci (CFat } \\
29 \mathrm{v}, 75 \mathrm{v})\end{array}$ \\
\hline vêr- & 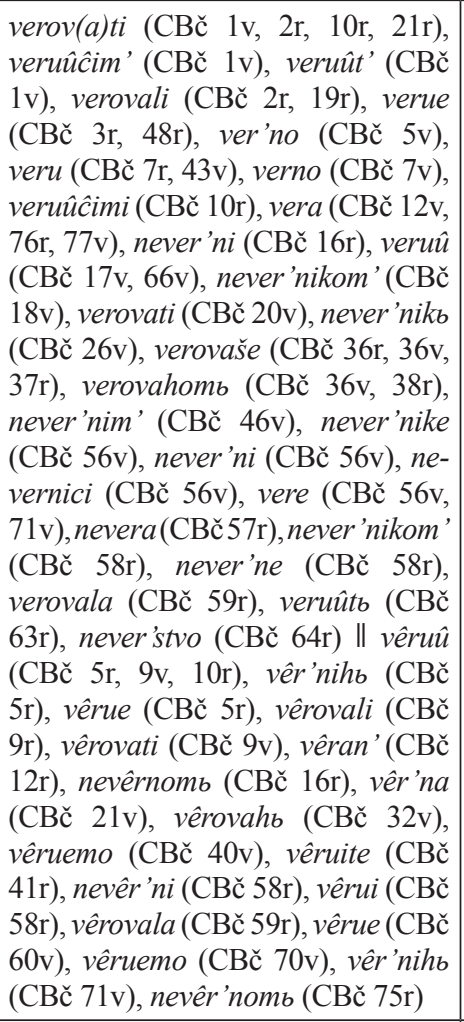 & 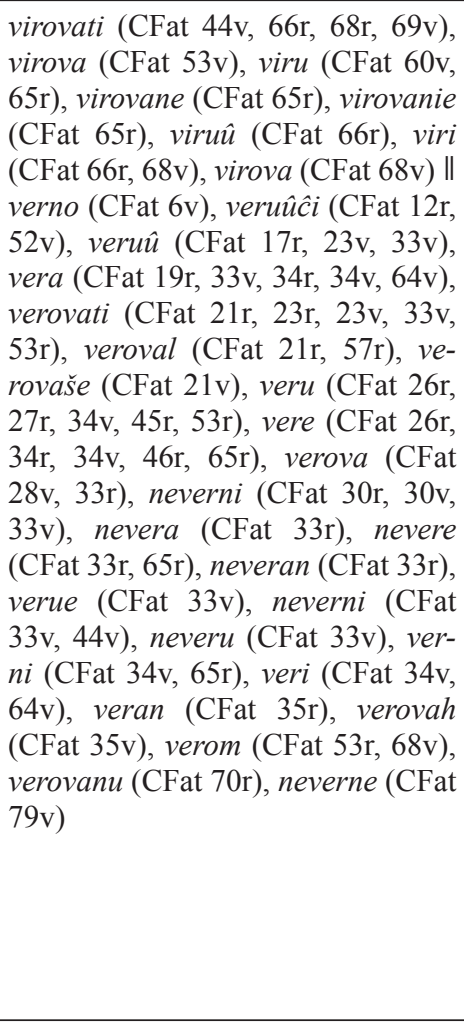 \\
\hline -vês- & $\begin{array}{l}\text { obisi (CBč 56v), obisiti (CBč 63r), } \\
\text { obisiše (CBč 63r) }\end{array}$ & obisiše (CFat 29r) \\
\hline
\end{tabular}




\begin{tabular}{|c|c|c|c|}
\hline \multicolumn{2}{|c|}{ Korijen } & CBč & CFat \\
\hline \multirow{3}{*}{-vêt- } & 'savjet' & $\begin{array}{l}\text { s'vit'nici (CBč 3v), svit'ni (CBč } \\
\text { 62r), svit'nice }(\mathrm{CBč} 71 \mathrm{v}), \text { svit'nikb } \\
(\mathrm{CBč} 76 \mathrm{v}) \| \text { ll svet'nici }(\mathrm{CBč} 3 \mathrm{v}),\end{array}$ & $\begin{array}{l}\text { svitovaniê }(\mathrm{CFat} 7 \mathrm{r}), \text { svit }(\mathrm{CFat} 28 \mathrm{r}, \\
71 \mathrm{v}), \text { svitovati }(\mathrm{CFat} 39 \mathrm{r})\end{array}$ \\
\hline & 'odgovor' & $\begin{array}{l}\text { otveĉav' (CBč 35r, 36r), otveĉav'ša } \\
\text { (CBč 37r) II otvêcav'(CBč 34v, 35r, } \\
\text { 35v, 36r, 37v, 41v), otvêcavb (38r) }\end{array}$ & - \\
\hline & 'zavjet' & zavet (CBč 55v) & - \\
\hline \multicolumn{2}{|l|}{ vêtr- } & 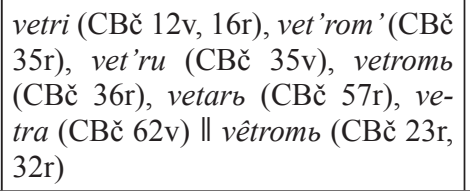 & $\begin{array}{l}\text { vitar (CFat 60v) \| vetar (CFat 10v), } \\
\text { vetri (CFat 60v) }\end{array}$ \\
\hline \multicolumn{2}{|l|}{ vrêm- } & $\begin{array}{l}\text { vrime }(\mathrm{CBč} 2 \mathrm{v}, 4 \mathrm{r}, 9 \mathrm{r}, 10 \mathrm{v}, 16 \mathrm{v}, 20 \mathrm{v}, \\
40 \mathrm{v}, 47 \mathrm{v}, 61 \mathrm{v}) \text {, vrima }(\mathrm{CBč} 23 \mathrm{r}), \\
\text { v'rime }(\mathrm{CBč} 32 \mathrm{v}), \text { vrimene }(\mathrm{CBčc} \\
39 \mathrm{r}, 54 \mathrm{v}), \text { vrimena }(\mathrm{CBč} 56 \mathrm{r}, 56 \mathrm{v}), \\
\text { vrimenihb (CBč 52v), vrimenb } \\
(\mathrm{CBč} 52 \mathrm{v}) \| \text { vrêmen'no }(\mathrm{CBč} 73 \mathrm{v}), \\
\text { vrême }(\mathrm{CBč} 75 \mathrm{v})\end{array}$ & $\begin{array}{l}\text { vrimene (CFat 2r, 6r, 25r, 28v), vri- } \\
\text { me (CFat 2r, 5r, 9v, 11r, 13v, 14v, } \\
15 \mathrm{r}, 18 \mathrm{r}, 20 \mathrm{r}, 21 \mathrm{v}, 23 \mathrm{r}, 25 \mathrm{r}, 34 \mathrm{r}, 27 \mathrm{v}, \\
44 \mathrm{r}, 49 \mathrm{r}, 50 \mathrm{v}, 51 \mathrm{v}, 55 \mathrm{r}, 56 \mathrm{r}, 56 \mathrm{v}, \\
60 \mathrm{r}, 63 \mathrm{r}) \text {, vrimena }(\mathrm{CFat} 2 \mathrm{r}, 5 \mathrm{v}, 11 \mathrm{r}, \\
46 \mathrm{r}, 50 \mathrm{r}, 54 \mathrm{r}, 60 \mathrm{r}, 70 \mathrm{r}, 78 \mathrm{v}), \text { vrimeni } \\
(\mathrm{CFat} 13 \mathrm{v}) \text {, vrimenih }(\mathrm{CFat} 75 \mathrm{v})\end{array}$ \\
\hline \multicolumn{2}{|l|}{ zvêr- } & $\begin{array}{l}\text { z'virb (CBč } 12 \mathrm{v}, 68 \mathrm{v}), z^{\prime} \text { 'viri }(\mathrm{CBčc} \\
45 \mathrm{v}, 71 \mathrm{r}), z^{\prime} \text { vire }(\mathrm{CBč} 69 \mathrm{v}) \text { II zvêri } \\
(15 \mathrm{v}, 43 \mathrm{r}), z^{\prime} \text { 'vêri }(\mathrm{CBč} 20 \mathrm{r}, 43 \mathrm{r})\end{array}$ & $\begin{array}{l}\text { zviri (CFat 6r, 7v, 9v, 27v, 46v, 61r, } \\
\text { 64r, 71v, 77v), zvir (CFat 47r, 65r) }\end{array}$ \\
\hline \multicolumn{2}{|c|}{ zvêzd- } & $\begin{array}{l}z^{\prime} v e \hat{z}{ }^{\prime} d i(\mathrm{CBč} 16 \mathrm{r}, 16 \mathrm{v}, 20 \mathrm{v}, 72 \mathrm{v}), \\
\left.z^{\prime} v e ̂ z d u \text { (CBč } 49 \mathrm{r}\right), z^{\prime} v e \hat{z}{ }^{\prime} d u(\mathrm{CBčc} \\
\text { 51r), zv'êzdo (CBč 71v) }\end{array}$ & $\begin{array}{l}\text { zvizde (CFat 47r) II zvezdami (CFat } \\
7 \mathrm{v}), \text { zvezdam (CFat 9v), zvezdah } \\
(\mathrm{CFat} 14 \mathrm{r}, 15 \mathrm{v}, 16 \mathrm{r}) \text {, zvezde (CFat } \\
\text { 16r, 17r, 22v, 30r), zvezdi (CFat } 17 \mathrm{v}, \\
25 \mathrm{r}, 30 \mathrm{r}), \text { zvezdu }(79 \mathrm{r})\end{array}$ \\
\hline \multicolumn{2}{|c|}{ ž(d)rêb- } & $\begin{array}{l}\text { žrib' (CBč 39r), ž'rib' (CBč 39r), } \\
\text { ž'ribomb (CBč 39r) II ̌̌'rêb' (CBč } \\
\text { 34r), žrêb' (CBč 34r) }\end{array}$ & ždribi (CFat 24r, 71v) \\
\hline \multicolumn{2}{|l|}{ želêz- } & želez'nimi (CBč 10r) & železnimi $($ CFat 29v, 79v) \\
\hline
\end{tabular}

Tablica 1: Odrazi jata u korijenskim morfemima u Berčićevu i Fatevićevu zborniku

Table 1: Reflections of jat in the root morphemes in the Miscellany from Berčić Collection No. 5 and the Fatevic Miscellany of spiritual texts

Podatci iz Tablice 1 pokazuju da je odraz jata, ne uzimajući u obzir primjere iz Berčićeva zbornika u kojima je na mjestu praslavenskoga jata bilježeno slovo B, u obama zbornicima isključivo ili pretežno ekavski u korijenima navedenima u (44), što je i očekivano s obzirom na zakonitost Jakubinskoga 
i Meyera. Očekivani ekavski odraz jata u Berčićevu zborniku usto isključivo ili pretežno dolazi i u oblicima s korijenima navedenima u (45). U Fatevićevu se zborniku u tim korijenima ostvaruju ikavski i ekavski primjeri, s tim da njihov omjer varira pa je u nekim korijenima broj primjera s ikavskim i ekavskim odrazom podjednak, u nekima prevladavaju ekavski primjeri, a u nekima je veći broj primjera s ikavskim odrazom. Kod korijena svêd- potvrđeni su isključivo oblici s ikavskim odrazom jata. Ikavizmi prevladavaju i u korijenu svêt- ('svjetlo'), kod kojega su oblici s ekavskim odrazom jata podjednako rijetko raspodijeljeni po čitavome zborniku, odnosno po različitim zborničkim tekstovima.

(44) besêd-, cêl-, krês-, nevêst-, smêr-, vêk- i želêz-

(45) dêl- 'djelo', mên-, mêst-, slêd-, srêd-, svêd-, svêt- 'svjetlo', têl-, vêr-, vêtr-.

Drugačija je u Fatevićevu zborniku situacija s korijenima navedenima u (46), kod kojih je - neovisno o raspodjeli ikavskih i ekavskih oblika na razini čitavoga zbornika - većina oblika s ikavskim odrazom jata potvrđena u tekstu Zrcala duhovnoga, koji je, kako je ranije istaknuto, Fatevićev prijepis Žorulićeva prijevoda djela fra Angela Milanesea Speculum spirituale:

(46) dêl- 'djelo', mêst-, slêd-, srêd-, têl-, vêr-, vêtr-.

Primjerice, od 22 potvrđena ikavska oblika s korijenom mêst- njih čak 20 zabilježeno je u tekstu Zrcala duhovnoga, dok je 19 ekavskih pravilno raspodijeljeno po drugim zborničkim tekstovima; od četiriju oblika s korijenom vêtr- oba oblika s ikavskim odrazom jata potvrđena su u Zrcalu duhovnome (na istome listu); od četiriju potvrđenih oblika s ikavskim odrazom jata u korijenu srêd- tri su zabilježena u Zrcalu duhovnome, a samo jedan u ostalim tekstovima; od 65 potvrđenih oblika s korijenom vêr-svih 13 ikavskih potvrđeno je u Zrcalu duhovnome. Slične tendencije - doduše, nešto slabije izražene - uočljive su i u oblicima s korijenima dêl-('djelo'), slêd-i têl-. Takvo stanje zasigurno nije plod slučajnosti i pisarova proizvoljna smjenjivanja ikavskih i ekavskih oblika, već bi moglo ukazivati na to da je tekst Zrcala duhovnoga prepisan s matice u kojoj je odraz jata bio ikavski. U prilog tomu govori i stanje u korijenima besêd- i zvêzd-, koji su u Fatevićevu zborniku - očekivano, s obzirom na zakonitost Jakubinskoga i Meyera - dominantno ekavski. Međutim, rijetki oblici s ikavskim odrazom jata isključivo se ili pretežno ostvaruju u tekstu Zrcala duhovnoga. ${ }^{23}$

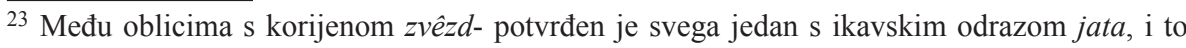
u tekstu Zrcala duhovnoga, dok je kod korijena besêd- potvrđeno sedam oblika s ikavskim odrazom, od čega četiri u tekstu Zrcala duhovnoga. 
Oblici s korijenima navedenima u (47) u Fatevićevu zborniku isključivo su ekavski:

(47) bêl-, bês-, kolên-, pêsn-, pê(v)-, vênc-.

Uglavnom su ekavski i oblici s korijenom lêt-. U tome su korijenu, doduše, potvrđena i tri oblika s ikavskim odrazom jata, no sva tri zabilježena su u kraćim tekstovima (potpisima) koji su naknadno upisani na prazne stranice zbornika, ${ }^{24}$ i to vjerojatno na ikavskome, pakoštanskome području. U Berčićevu zborniku u korijenima bêl-, bês-, pêsn- bilježi se isključivo slovo B. U korijenu vênc-, uz oblike s tradicionalnim grafemom za jat, potvrđena su po tri ikavska i ekavska oblika, po jedan je ikavski i ekavski oblik zabilježen u korijenima kolên- i pê(v)-, dok su u korijenu lêt- od triju potvrđenih oblika dva ikavska, a u jednome se na mjestu jata bilježi slovo B.

Prema zakonitosti Jakubinskoga i Meyera, ekavski odraz jata u obama bi se zbornicima očekivao i u korijenima navedenima u (48):

(48) cên-, cvêt-, lên-, prêd-, rêz-.

Stvarno je stanje takvo da je u Fatevićevu zborniku u jedinome potvrđenom obliku s korijenom cên- odraz jata doista ekavski. U korijenima lên- i rêz-odraz je jata isključivo ili gotovo isključivo ikavski (s korijenom lên-, doduše, potvrđen je tek jedan oblik, dok je od ukupno trinaest oblika s korijenom rêz-dvanaest ikavskih), a isti odraz izrazito prevladava i u korijenima prêd-i cvêt-, pri čemu primjeri s tim odrazom nisu koncentrirani samo u jednome ili dvama zborničkim tekstovima (ili samo u tekstu Zrcala duhovnoga). U Berčićevu su zborniku oblici sa spomenutim korijenima potvrđeni prilično rijetko. S korijenoma cên- potvrđena su svega dva oblika, i to oba ikavska. S korijenom rêz-zabilježena su četiri oblika, s tim da se $\mathrm{u}$ trima pojavljuje tradicionalni grafem za jat, dok je u jednome odraz jata ikavski. U korijenima cvêt- i lên-, uz malobrojne primjere s tradicionalnim grafemom za jat, potvrđeni su i oblici s ikavskim i ekavskim odrazom, i to s korijenom cvêt- jedan ikavski i jedan ekavski oblik, a s korijenom lên- dva oblika s ekavskim i jedan oblik s ikavskim odrazom jata. Obilnije su zastupljeni samo oblici s korijenom prêd- u kojima izrazito prevladava ekavski odraz.

I u jednome i u drugome zborniku jat se pretežno ili isključivo odrazio ikavski u korijenima navedenima u (49):

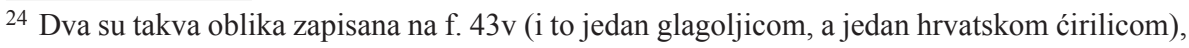
a jedan na f. $80 \mathrm{v}$.
} 
(49) crêkv-, človêk-, dêl- 'dio', dêt-, dêv-, êd-, gnêv-, grêh-, hlêb-, krêp-, lêk-, lêp-, lêv-, -lêz-, mêsec-, -vês-, pênez-, plên-, rêc-, rêk-, sêk-, slêp-, snêg-, têh-, vrêm-, zvêr-, ž(d)rêb-.

U Fatevićevu zborniku odraz jata isključivo je ikavski i u šest korijena navedenih u (50). U Berčićevu zborniku oblici s korijenom strêl- nisu potvrđeni. Oblici s korijenom svêt- 'svijet' imaju ekavski odraz jata, a u korijenima bêg- i drêv-, uz oblike s tradicionalnim grafemom za jat u korijenu, ostvaruju i ikavski i ekavski oblici. Oblici s korijenom -vêt-, u cjelini gledano, podjednako su često ikavski i ekavski, s tim da je raspodjela odraza tijesno povezana sa značenjem. Oblici koji su povezani sa značenjem 'savjet' gotovo su isključivo ikavski (potvrđen je samo jedan ekavski oblik), oblici povezani sa značenjem 'odgovor' imaju ekavski odraz jata, a nerijetko se bilježe i s tradicionalnim grafemom za jat, dok je jedini potvrđeni oblik sa značenjem 'zavjet' ekavski. S korijenom brêm- pak potvrđen je svega jedan oblik, i to s tradicionalnim grafemom za jat.

(50) bêg-, brêm-, drêv-, strêl-, svêt- 'svijet', -vêt-.

Sveukupno gledajući, u Fatevićevu je zborniku 42 korijena pretežno ili isključivo ikavska (51), dok je pretežno ili isključivo ekavskih 18 (52):

(51) bêg-, brêm-, crêkv-, cvêt-, človêk-, dêl- 'dio', dêt-, dêv-, drêv-, êd-, gnêv-, grêh-, hlêb-, krêp-, lêk-, lên-, lêp-, lêv-, -lêz-, mên-, mêr-, mêsec-, -vês-, pênez-, plên-, prêd-, rêč-, rêk-, rêz-, sêk-, slêd-, slêp-, snêg-, strêl-, svêd-, svêt- 'svjetlo', svêt- 'svijet', têh-, -vêt-, vrêm-, zvêr-, z̆(d)rêb-

(52) bêl-, besêd-, bês-, cêl-, cên-, kolên-, krês-, lêt-, nevêst-, pêsn-, pê(v)smêr-, srêd-, vêk-, vênc-, vêr-, zvêzd- i želêz-.

Približno je sličan omjer korijena s ikavskim odnosno ekavskim odrazom jata i u Berčićevu zborniku, s tim da je u njemu zbog razmjerno visoke čestotnosti pojavljivanja slova B na mjestu praslavenskoga jata i jednih i drugih nešto manje. Tako je u trideset korijena jat isključivo ili pretežno ikavski (53), dok je u sedamnaest korijena jat isključivo ili pretežno ekavski (54). U (51) i u (53), odnosno u (52) i u (54) masnim su slovima označeni korijeni u kojima je prevladavajući odraz jata jednak i u jednome i u drugome zborniku:

(53) cên-, crêkv-, človêk-, dêl- 'dio', dêt-, dêv-, êd-, êzd-, gnêv-, grêh-, hlêb-, krêp-, lêk-, lêp-, lêt-, lêv-, -lêz-, mêd-, mêsec-, -vês-, pênez-, plên-, rêč-, rêk-, sêk-, slêp-, snêg-, têh-, vrêm-, zvêr-, z̆(d)rêb-

(54) besêd-, cêl-, dêl- 'djelo', krês-, mên-, nevêst-, prêd-, slêd-, smêr-, svêt- 'svjetlo', svêt- 'svijet', svêd-, têl-, vêk-, vêr-, vêtr- i želêz-. 
Prevlast ikavskoga odraza jata očita je, dakle, i u jednome i u drugome zborniku. Znakovito je i to da se zakonitost Jakubinskoga i Meyera u obama zbornicima u pravilu krši »u korist « ikavskoga odraza jata ${ }^{25}$ pa su tako, primjerice, u Fatevićevu zborniku korijeni cvêt-, lên-, prêd-, rêz-, slêd-, strêl-, svêd-, svêt- 'svjetlo', svêt- 'svijet' -vêt-, zvêr- pretežno ili isključivo ikavski premda bi se po zakonitosti Jakubinskoga i Meyera očekivalo da budu ekavski, a isto u Berčićevu zborniku vrijedi za korijene cên-, lêt- i zvêr- ${ }^{26}$ To pokazuje da su zbornici doista mogli nastati na južnijem srednjočakavskom području, tj. na onome ikavsko-ekavskom području na kojem se snažnije no drugdje osjećaju ikavski utjecaji - a upravo je takvo u vremenu nastanka zbornika bilo zadarsko područje.

U tvorbenome sufiksu kojim se od korijena dobiva infinitivna osnova glagola tipa gorêti, letêti, trpêti, vidêti, želêti itd. jat se i u jednome i u drugome zborniku u većini primjera odrazio ikavski, kako se vidi u (55). Primjeri s ekavskim odrazom potvrđeni su vrlo rijetko, i to samo u Berčićevu zborniku (56) u kojem ima i nešto primjera bilježenja tradicionalnoga grafema za jat u tvorbenome sufiksu (57):

(55) goriti (CBč 19v, 56v), poletiše (CBč 28r), strpil (CBč 32r), trpihb (CBč 37v), trpiti (CBč 43r, 50v), vidili (CBč 11v, 20r, 34v), viditi (CBč 1v, 11v, 15v, 21r, 30r, 43r), bolil (CFat 4r), goriti (CFat 46v, 47r, 78r), poletiše (CFat 78r), trpiti (CFat 29v, 56r), vidivši (CFat 20r, 25v, 29r, 30r), viditi (CFat 3r, 13v, 46r, 62v), želila (CFat 22v)

(56) videlb (CBč 36v), videv' (CBč 37r)

(57) tr'pêti (CBč 35v), z'rêv' (CBč 37v), želêhb (CBč 24r).

U prefiksu nê- u Fatevićevu zborniku ostvaruje se isključivo ikavski odraz jata (58). Taj odraz prevladava i u Berčićevu zborniku, s tim da u njemu ima i nešto potvrda bilježenja slova B u prefiksu, kako se vidi u (59):

${ }^{25}$ Slično je stanje u Klimantovićevu zborniku I. u kojem su odstupanja od pravila Jakubinskoga i Meyera uglavnom potvrđena u primjerima u kojima se očekuje ekavski odraz jata: s'vita (RitKlim 76v), c'vita (RitKlim 76v), tilo (RitKlim 76v), nedilû (RitKlim 184v), vridna (RitKlim 218v) (usp. također LOZIĆ KNEZOVIĆ 2016).

${ }^{26} \mathrm{~S}$ obzirom na potvrđene oblike, na prvi se pogled čini da prevlast oblika s ikavskim odrazom jata u korijenu -lêz- također predstavlja odstupanje od pravila Jakubinskoga i Meyera. Treba, međutim, imati na umu da je odraz jata određen polaznim oblikom riječi te se u pravilu ne mijenja u ostalim oblicima, neovisno o promjeni fonološke okoline u kojoj se nalazi jat (usp. LUKEŽIĆ 1990: 13). Kako se kod korijena -lêz-radi mahom o glagolskim oblicima kod kojih je polazni oblik infinitiv (npr. ulisti CFat 62v, v'listi CBč 63v), ikavski odraz nije neočekivan s obzirom na pravilo Jakubinskoga i Meyera. 
(58) niki (CFat 5r, 5v, 15v, 30r), nike (CFat 6r, 7r), nikih (CFat 6v), niko (CFat 9v, 15v, 18r), niku (CFat 18r, 29r), nikoliko (CFat 18v, 24r, $42 \mathrm{v}, 45 \mathrm{v})$, nici (CFat 27v, 50r, 50v, 56r), nicih (CFat 52v, 55r), nigda (CFat 62r)

(59) niki (CBč 1r), nikoi (CBč 1r), nike (CBč 45r), nika (CBč 46r), nikihb (CBč 55r), nikoliko (CBč 11v, 39r), nici (CBč 1r, 1v, 2v, 10v, 66v), nikada (CBč 70r) I| nêkoliko (CBč 24v), nêkotêromu (CBč 39v), nêkim' (CBč 53v).

Drugačija je situacija s prefiksom prê-. U Fatevićevu zborniku, ukupno gledajući, u tome se prefiksu jat podjednako često odrazio kao $i(60)$ i kao $e$ (61), s tim da je ikavizama nešto više u Fatevićevu prijepisu Zrcala duhovnoga, a ekavizama u ostalim tekstovima u zborniku. Drugačija je situacija u Berčićevu zborniku u kojem prevladavaju ekavizmi (62), ikavizmi se ostvaruju samo iznimno (63), dok je u nemalome broju primjera u prefiksu zabilježen tradicionalni grafem za jat (64):

(60) pribivanie (CFat 1v), prislatka (CFat 21r), pribudut (CFat 11r), prilastiti (CFat 15r), priporuči (CFat 20v), pridobri (CFat 48v), primoguci i (CFat 48v), prirazumni (CFat 48v), pripočteni (CFat 49r), privelik (CFat 52r), primore (CFat 52r), priteškimi (CFat 55v)

(61) prelubodeistva (CFat 16v), prestolu (CFat 17r, 62v), prebivali (CFat $18 \mathrm{r})$, prebivati $(\mathrm{CFat} 18 \mathrm{v})$, presveto $(\mathrm{CF}$ at $23 \mathrm{v})$, pretežak (CFat $30 \mathrm{v})$

(62) prelûtimi (CBč 9r), presil’nimb (CBč 10r), prečas 'tnomu (CBč 13r), predai (CBč 10r), pretiho (CBč 11v), preveliko (CBč $14 \mathrm{v})$, preteš’ko (CBč 14v), prekloni (CBč 37r), pretrpi (CBč 45r), pregrešihs (CBč 54v), premilo (CBč 56r), predah'nuti (CBč 66r), predragu (CBč 69v)

(63) pristrašans (CBč 33v)

(64) prêdaût' (CBč 31v), prêstola (CBč 13v), prês'(ve)tlaê (CBč 15r), prêčas tni (CBč 14r), prêslav'na (CBč 30r), prêslat'ki (CBč 30v), prêbivali (CBč 30v), prêlomi (CBč 44r), prêlipa (CBč 77r).

U Fatevićevu zborniku potvrđeno je i nekoliko primjera hiperikavizama (65). ${ }^{27}$ Analogni su primjeri potvrđeni i u drugim neliturgijskim zbornicima

$\overline{{ }^{27} \text { Neki primjeri u }}$ (65) (kamine, zlamina) mogli bi se, doduše, tumačiti i zatvaranjem poluotvorenoga $e$ u $i$ u slogu koji je zatvoren nazalom [ kamin $+j e]$. Takvo tumačenje ima uporište $\mathrm{u}$ činjenici da su zatvaranja otvorenih i poluotvorenih samoglasnika u slogovima koji su zatvoreni nazalom vrlo česta u srednjočakavskim govorima (usp. npr. BENIĆ 2013: 24-25; BENIĆ 2014: 69-71; ŠPRALJA 2016.b: 14-20). Protiv njega, međutim, govore primjeri tipa stvorene [stvoreńe] (CFat 14v), utišene [utišeńe] (CFat 18r) i mnogi drugi u kojima nije došlo do prijelaza $e>i$ u slogu zatvorenu nazalom. 
(66) (usp. također MIHALJEVIĆ, A. 2014: 223; LOZIĆ KNEZOVIĆ 2016: 46) i u nekim suvremenim čakavskim govorima (usp. BENIĆ 2014: 62):

(65) zlamina (CFat 29r), znamina (CFat 16r, 16v, 18v), kamine (CFat 13v, $16 \mathrm{r}, 22 \mathrm{v}, 27 \mathrm{v}, 30 \mathrm{r})$, postili (CFat 11r, 11v, 20v, 58r, 61r), postilicom (CFat 20r), postilu (CFat 20v, 21r, 24v, 61r), vičeru (CFat 72v), vičernu (CFat 76r)

(66) postili (CPetr 71r), vičerali (CPetr 77r); vičeri (RitKlim 3r), kamin'e (RitKlim 59v), postilû (RitKlim 86v); kamin'em' (CIvan 117r).

Benić smatra da je $i$ u obliku kamînje, koji nalazi u kukljičkome govoru, moglo nastati analogijom prema kâmik. Analogija je mogla djelovati i prema primjerima tipa vidinie [vidinje] (CFat 21v), hotine [hotinee] (CFat 36r, 36v, 37 r) u kojima se $i$ očekivano ostvaruje na mjestu etimološkoga jata.

\subsection{Odrazi poluglasa}

Već je istaknuto da u Fatevićevu zborniku štapić, a u Berčićevu zborniku štapić i apostrof - kao jedini znakovi obilježavanja nekadašnjega poluglasa - nemaju nikakvu fonološku vrijednost te se upotrebljavaju ponajprije kao ostatci pisarske tradicije. Općenito govoreći, poluglas je u obama zbornicima uglavnom dosljedno vokaliziran u jakome položaju, tj. u slogu pred slabim jerom ili u jedinome slogu u riječi ako ta riječ nije klitika, dok je u slabome položaju, tj. na kraju riječi ili u slogu pred kojim drugim samoglasnikom ili jakim jerom, uglavnom dosljedno izgubljen (usp. HCSL 2014: 80).

U obama zbornicima, međutim, ima odstupanja od toga općeg pravila, i to prije svega u smislu vokalizacije jera u tzv. slabom položaju. Vokalizacija slabih jerova u Fatevićevu zborniku, kao općenito u brojnim slavenskim jezicima, osobito je česta u prvome slogu riječi u primjerima tipa magle (CFat 6r), zali (CFat 11r, 44v, 50r, 64r), tamnicu (CFat 24r), lagati (CFat 34v), šalem (CFat 42v) ${ }^{28}$ Takvih primjera ima i u Berčićevu zborniku, kako se vidi u (67), no u njemu je zabilježeno i mnogo potvrda u kojima u navedenome položaju poluglas nije vokaliziran, nego se na njegovu mjestu bilježi apostrof (68).

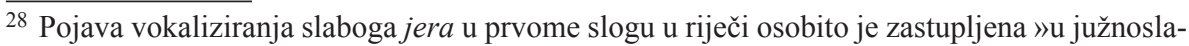
venskim jezicima i na krajnjem slavenskom sjeverozapadu, u polapskome i drugim izumrlim slavenskim govorima na sjeveru Njemačke« (MIHALJEVIĆ 2002: 204) te se objašnjava na različite načine: težnjom izbjegavanja neobičnih suglasničkih skupina, naglaskom, brojem slogova, analogijom itd. (usp. MIHALJEVIĆ 2002: 204; HCSL 2014: 80). Usp. također SHEVELOV 1964: 448-452. 
Rijetko se primjeri nevokaliziranja poluglasa u tome položaju mogu pronaći i u Fatevićevu zborniku (69):

(67) mag'li (CBč 30v), maz'du (CBč 16v 18v, 20v, 33v), šalu (CBč 38r), maši $(\mathrm{CBč} 52 \mathrm{v}, 60 \mathrm{v})$

(68) m'glahb (CBč 15v), t'mah' (CBč 15v, 20r), t'moû (CBč 18r), t'ma (CBč 15v, 19r), t'mê (CBč 19v), t'mahb (CBč 20r), t'mu (CBč 28r, 74v), t’m'nici (CBč 40v), z'li (CBč 64v, 68r, 68v)

(69) zli (CFat 10r), šle (CFat 50r).

Osim u spomenutim primjerima, koji su, kako smo istaknuli, potvrđeni i u drugim slavenskim jezicima, u Berčićevu i Fatevićevu zborniku, kao i u drugim hrvatskoglagoljskim liturgijskim i neliturgijskim zbornicima nastalima na čakavskome području, slabi se poluglas nerijetko vokalizirao i u položajima koji ukazuju na tzv. čakavsku jaku vokalnost (70) (usp. LISAC 2009: 17). Uz te se oblike, međutim, mogu pojaviti i odgovarajući primjeri bez vokalizacije slaboga poluglasa (71):

(70) mani (CBč 16v, 26v, 65v), kade (CBč 7r, 30v, 38r), kadi 'gdje' (CBč 2r, 4r, 26r, 42r); manom (CFat 1v), s manu (CFat 1v), mani (CFat $10 \mathrm{v}, 11 \mathrm{r}, 20 \mathrm{r}, 62 \mathrm{v}, 64 \mathrm{r})$

(71) mnoû (CBč 4v, 20v, 22r, 30r, 46v), m'ne (CBč 21v, 23r), mnom (CFat $1 \mathrm{v}, 62 \mathrm{v}, 72 \mathrm{v})$, mne (CFat 14v), g'di (CBč 26r, 26v, 63v), g'de (CB̌̌ 74r), gdi (CFat 17r, 44r, 48v, 63v, 64r).

Kao i u drugim hrvatskoglagoljskim tekstovima, vokalizacija je slabih jerova u obama zbornicima česta i pred sufiksima $-s k$ - i -stv-, i to obično $\mathrm{u}$ susjedstvu palatala (72) (usp. HCSL 2014: 80), a rjeđe i u susjedstvu nepalatalnih glasova (73). Primjeri nevokaliziranja slaboga poluglasa iza palatalnih glasova vrlo su rijetki, osobito u Fatevićevu zborniku (74):

(72) knežas'tviê (CBč 17r), božas'tvene (CBč 68v), hodočastvo (CBč 75r), množas'tvo (CBč $17 \mathrm{r}, 17 \mathrm{v})$, sv(ê)dočastvo (CBč 1v), prišastviê (CBč 15r), prišast'vie (CBč 31r), proročaskie (CBč 12r), v'sačaskih' (CBč 74v); množastvo (CFat 1r, 10v), čllovič)aski (CFat 1v), divičaskimi (CFat 1v), človičastvo (CFat 2r, 2v), vsačaskim (CFat 2r), božastvo (CFat 3r), božastveno (CFat 5r), eretičastva (CFat 6v), ubožastvom (CFat 6v, 16v), veličastviê (CFat 11r), proročastvo (CFat 15r, 73r, 73v), svidočastvo (CFat 16v, 17r, 46r), otočastva (CFat 37v), katuličaske (CFat 66r)

(73) bogatastvo (CBč 18r, 32r, 32v, 64v), bogatastva (CBč 22r), bogatastvomb (CBč 76v), bogatas'tvo (CBč 73v); cesarastvueš 
(CFat 1r), cesarastvi (CFat 4v), cesarastvo (CFat 30v), bogatastvo (CFat 8v, 17r), bogatastva (CFat 8v)

(74) svêdeč stvo (CBč 20v), ezič skû̂ (CBč 36v), kataličbskuû (CBč 48r), bližič stvi (CBč 65r); množstvo (CFat 62v).

Sekundarni su jerovi u Berčićevu i Fatevićevu zborniku uglavnom dosljedno vokalizirani (75), dok se oblici bez umetanja sekundarnoga jera i u jednome i u drugome zborniku ostvaruju samo iznimno (76):

(75) bolezans (CBč 67v, 70r, 70v), bolêzan' (CBč 72v), dobarb (CBč 67r, 70v), esam' (CBč 35v), korabalb (CBč 10v, 11r, 11v, 22r, 23r), ogan' (CBč 3r, 20r, 40v, 42v, 59r, 62v, 75r), misalb (CBč 52v, 59v), mogal' (CBč 48r, 48v, 57r), rekalb (CBč 6r), rekal' (CBč 12v, 71v), sedamb (CBč 70r), vetarb (CBč 57r), žizan' (CBč 46v); esam (CFat 9r, 11v, 15v, 18v, 29r, 58r, 64v), dobar (CFat 35r, 37v, 77r), vetar (CFat 10v), vitar (CFat 60v), petar (CFat 15r, 20v, 26r, 70v), rekal (CFat 5v, 43r, 57r, 71r), ogan (CFat 10v, 14v, 18r, 39v, 55r, 79r), bolizan (CFat 11r, $11 \mathrm{v}, 29 \mathrm{v}, 34 \mathrm{r}$ ), misal (CFat 4r, 14v, 25r, 32r, 34r, 36r, 62r), sedam (CFat 23r, 42v, 55v, 78r)

(76) esm' (CBč 8v), esmb (CBč 15r, 74v), pêsnb (CBč 19r), misl (CFat $36 r)$.

Rijetki su u obama zbornicima i primjeri analoškoga umetanja odraza sekundarnoga jera u oblike kosih padeža (77):

(77) misal'û (CBč 12r); bolizanu (CFat 9v), bolizaniû (CFat 11v), misalu (CFat 36r).

Napeti jerovi u jakim položajima na kraju osnove imaju pravilan refleks pa se na njihovu mjestu redovito ostvaruje $\hat{e}[j a]$ (78). U kosim padežima, gdje je napeti jer u slabome položaju, potvrđeni su samo oblici s $i[j](79)$ :

(78) dostoên' (CBč 12v, 21v, 23r, 43r), dostoênb (CBč 45r), dostoên (CFat 5r, 32r, 33r, 43r), dostoênstva (CFat 48v), dostoênstvo (CFat 67r)

(79) nedostoinu (CBč 21v), otaino (CBč 22r), taino (CBč 52r), otaine (CBč 71r), taine (CBč 71r); dostoino (CFat 5v, 18r), dostoini (CFat 18r, 49r), taina (CFat 39r), taini (CFat 10v), otainom (CFat 3v), otainu (CFat 32r), otaina (CFat 39r), otaino (CFat 36r, 38v), otainim (CFat 72v).

U obama se zbornicima jerovi nerijetko vokaliziraju u prijedlozima i prefiksima. Općenito govoreći, primjeri se vokaliziranja jerova u prijedlozima i 
prefiksima mogu predvidjeti trima pravilima koja vrijede i za druge hrvatskoglagoljske tekstove nastale od polovice 13. st. (usp. HCSL 2014: 81). Jerovi se u prijedlozima (80) i prefiksima (81) obično vokaliziraju ako za njima slijedi slog sa slabim jerom:

(80) ka t'm 'nici (CBč 40v), sa mnu (CBč 4r), sa v'simi (CBč 10r), va d'ne (CBč 7r, 69v), va t'mah' (CBč 15v, 20r), va z'li (CBč 68r), va s'nê (CBč 73r); va svih (CFat 7r), va zli (CFat 10r), va sni (CFat 10r), $k a$ mni (CFat 10v, 42v), ka mne (CFat 14v), sa mnom (CFat 1v, 62v, 72v, $74 \mathrm{v})$, sa mnôे (CFat 10v, 21r)

(81) vač'nut' (CBč 1v, 2r, 45v), vač'nemo (CBč 7r), vaz'va (CBč 19r), vaz'mut' (CBč 57r), vazam' (CBč 22r), vazam 'ši (CBč 22r), vaz'mite (CBč 39r, 77r), vazme (CBč 56r), vaz'met' (CBč 51v), važ'gite (CBč 11r), važget' (CBč 57r), vag'na (CBč 42r), sabraše (CBč 41v), sab'rani (CBč $34 \mathrm{r})$, sabrati $(\mathrm{CBč} 47 \mathrm{v})$; vačnet (CFat 11r), vazmet (CFat 10v), vazmite (CFat 12r, 78r), vazmi (CFat 21r), vazam (CFat $25 \mathrm{v}, 26 \mathrm{v})$ važgu (CFat 16r), sabraše (CFat 11r), savkupi (CFat 4v, 24r), satkana (CFat 24r).

Da je vokaliziranje poluglasa iz prefiksa u tome položaju doista ovisno o (nekadašnjem) postojanju slaboga poluglasa u sljedećem slogu, pokazuje činjenica da se $u$ oblicima navedenih glagola $u$ kojima iza poluglasa iz prefiksa slijedi slog s punim samoglasnikom taj poluglas uglavnom ne vokalizira (82). Treba ipak naglasiti da je potvrđeno nešto primjera u kojima je i taj poluglas vokaliziran (83). I u jednome su i u drugome zborniku takvi primjeri rijetki, a više ih je u Fatevićevu zborniku:

(82) v'ze (CBč 8v, 23v, 38v, 52v, 60v), v'zeli (CBč 10v), v'zeše (CBč $11 \mathrm{v})$, v'zeti (CBč 23v), v'zes 'ta (CBč 37r), v'zeše (CBč 39r), v'zel' (CBč 51v), v'žegb (CBč 31v), z'berimo (CBč 39r), s'beremo (CBč 72r); vze (CFat 10r, 28r, 31v), vzel (CFat 10v), vzesta (CFat 12r), vzeta (CFat 20r, 21v, 26r), vzeše (CFat 24r, 73v), vzeti (CFat 41v)

(83) vaze (CBč 26r); vaze (CFat 11r, 20r, 24r), vazeti (CFat 18r), vazel (CFat 38v).

Jerovi se obično vokaliziraju i u prijedlozima i prefiksima iza kojih slijedi riječ koja započinje suglasnikom iste vrste kao i suglasnik koji se nalazi pred jerom (84). Dakako, u obama su zbornicima zabilježeni i primjeri nevokaliziranja poluglasa u ovome položaju (85), s tim da se u tim slučajevima u $F a$ tevićevu zborniku poluglas u prijedlogu uopće ne bilježi, dok se u Berčićevu zborniku, u kojem je takvih primjera znatno više, na mjestu poluglasa obično 
bilježi apostrof ili, rjeđe, štapić. U cjelini gledajući, i u jednome je i u drugome zborniku ipak znatno više primjera u kojima je poluglas vokaliziran nego primjera u kojima to nije slučaj.

(84) ka g(ospod)u (CBč 10r, 32v), ka korab'lû (CBč 11r), ka grobu (CBč 30r, 32v), ka kamiku (CBč 40v), sa s'trahomb (CBč 13r), sa sinom' (CBč 27v), sa ženami (CBč 18r), sa s'lzami (CBč 32v), sažga (CBč 42v), sazdah' (CBč 62r), sazdana (CBč 64v), va v'rata (CBč 42r), va vrime $(\mathrm{CBč} 2 \mathrm{v}, 47 \mathrm{v})$, va v(ê) ki (CBč $57 \mathrm{r})$, va vodu $(\mathrm{CBč} 57 \mathrm{v})$, va velikih' (CBč 67v), vavedet' (CBč 44v); ka kralu (CFat 34r), ka grobu (CFat 20v), sa svim (CFat 11r, 23v), sa svoim (CFat 22v, 53r), sa svoimi (CFat 23r), sa sinom (CFat 22r), sa slavom (CFat 21r), sa sobom (CFat 24v), sa soboû (CFat 25r), sa svetimi (CFat 35r, 69r), sa strahom (CFat 76r), sažgimo (CFat 20v), saznati (CFat 34r), vavek (CFat 21r), va večnom (CFat $1 \mathrm{v})$, va vrime (CFat 13v, 21v, 28v, 75v), va vsem (CFat 22v), va vsakom (CFat $78 \mathrm{r})$, va velike (CFat 27v), va veri (CFat $34 \mathrm{v})$, va vodu (CFat $10 \mathrm{v}, 74 \mathrm{v})$, va vičnoi (CFat 79v)

(85) s'strahomb (CBč 12r, 13r, 44r), s'sl'zami (CBč 24v, 73r), s'star'cem' (CBč 41r), s'slugami (CBč 41r), s'soboû (CBč 45v, 68r), s'ženu (CBč 51r), s'sv(e)timi (CBč 57r), s'z'lom' (CBč 69r), k' g(ospo)d(i)nu (CBč 9v, 11v, 17r), k'grêšs'nikom' (CBč 19v), k' knezem' (CBč 38v), v'v(ê)ki (CBč 30r, 33v, 46r, 47r), v'velikoi (CFat 17r), v'vrime (CFat 20v); s zlaminem (CFat 16r), s sulicom (CFat 16r), s ženom (CFat $28 \mathrm{r}$ ), v velike (CFat 36v), $k$ gospodinu (CFat 36r, 46v).

Treći položaj u kojem često dolazi do vokalizacije jera u prijedlozima i prefiksima jest onaj pred riječima koje započinju samoglasnikom (86). I u tome se položaju, međutim, jer ponekad ipak ne vokalizira (87). Češće se to događa u Berčićevu zborniku u kojem na mjestu poluglasa u spomenutome položaju obično dolazi apostrof, rjeđe štapić, a ima i primjera u kojima se na mjestu poluglasa ne bilježi nikakav znak.

(86) ka onoтu (CBč 11v), ka avramu (CBč 42v), sa oružiem' (CBč 52r), sa anj(e)li (CBč 58v), va iskušenie (CBč 6r), va idole (CBč 9r), va og'an' (CBč 21r), va ime (CBč 30r), va oblacehb (CBč 63r); ka anjelu (CFat 55v), ka isukarstu (CFat 64r), sa onom (CFat 23v), sa ovom (CFat 61v), sa ocem (CFat 30v), sa anjelom (CFat 32r), sa izbranimi (CFat 49v)

(87) k' otroku (CBč 23v), k' obručnici (CBč 23v), k onomu (CBč 10v), $k b$ i(su)su (CBč 34r), s'o(t)cemb (CBč 10r), s' ar'hibisk(u)p(o)mb (CBč 24v), s'uč(e)n(i)koma (CBč 35r, 35v), sb umilens'tvomb (CBč 
44v), sb anĵ(e)li (CBč 52v), v adamê (CBč 28v), v'ime (CBč 9v, 10r, $19 \mathrm{v})$, v onomb (CBč 11v), v'ogan' (CBč 25r), v oči (CBč 37v), vb ustihb (CBč 68v); k onomu (CFat 56r), s ovim (CFat 34r), s očima (CFat 62v).

Poluglas je u obama kodeksima često vokaliziran u svezama prijedloga $v b$ i akuzativnih oblika ličnih i pokaznih zamjenica (88). Takvo stanje potvrđeno je i u drugim zbornicima neliturgijskoga karaktera (89) (usp. također KOSIĆ 2010: 34; MIHALJEVIĆ, A. 2014: 224). Razlozi su vokalizacije u tome položaju po svemu sudeći akcenatske naravi. Naime, pretpostavi li se da je naglasak s akuzativnih zamjeničkih oblika preskakao na prijedlog, što je tipološki opravdano, s obzirom na to da je takva situacija i danas prisutna u zadarskim otočnim čakavskim govorima (usp. BENIĆ 2014: 319, 331; ŠPRALJA 2016.b: 33), vokalizacija (naglašenoga) poluglasa sasvim je očekivana. Tu pretpostavku mogla bi potvrditi i činjenica da u svezama prijedloga $v b$ i lokativnih zamjeničkih oblika vokalizacije obično nema, ili je barem svezā s vokaliziranim poluglasom u prijedlogu znatno manje negoli svezā u kojima do vokalizacije nije došlo (90), što bi se moglo objasniti činjenicom da u čakavskim govorima naglasak s tih oblika ne preskače na prijedlog (usp. BENIĆ 2014: 318-320).

(88) va n' (CBč 11v, 15r, 37r), va nb (CBč 24v, 36r, 46r), va nu (CBč 35r, $60 \mathrm{v})$, va me (CBč 20v), va t' (CBč 2v, 11v), va to (CBč 9r, 11r); va se (CFat 2v), va no (CFat 60r, 71v), va to (CFat 15r, 20r, 23r), va $t$ (CFat 33r)

(89) va čb (CIvan 91r), na t'(CIvan 101v); va me (CŽg 115v), va nu (CŽg 110r); va nû (CIvan 116r); va t' (CPetr 110v), va ta (CPetr 150v); va me (RitKlim 137r), va ne (RitKlim 186r)

(90) v' nemb (CBč 11v), v' nem' (CBč 13v), v' nei (CBč 5v, 9r, 35r), v' tomb (CBč 27r), v'sebê (CBč 54v); v tom (CFat 7r, 26v), v toi (CFat 20r), v nei (CFat 9v, 22r), v meni (CFat 28v).

U Fatevićevu zborniku slijed vb za prijedlog 'u' u otprilike polovici primjera zamijenjen je $\mathrm{s} u$, a u drugoj se polovici očuvalo $v$ (91). Raspodjela dvaju odraza pritom nije ni približno jednaka u svim dijelovima zbornika. $\mathrm{U}$ Zrcalu duhovnome uvjerljivo prevladava prijelaz $v b>u$, dok je u ostalim zborničkim tekstovima više primjera čuvanja $v$, premda je i prijelaz $v b>u$ vrlo čest. Važno je naglasiti da je kod prijedloga (i prefiksa) $v b$ refleks $u$ u Fatevićevu zborniku obilno potvrđen ne samo u nepozicionalnome značenju, kako je uobičajeno u hrvatskome crkvenoslavenskom, nego i u pozicionalnome značenju, kako se vidi iz primjera navedenih u (91). Drugačije je u Berči- 
ćevu zborniku u kojem se u pozicionalnome značenju u pravilu čuva $v b$, dok je refleks $u$ potvrđen samo iznimno (92):

(91) tudie bismo u bolizni $i \mathrm{v} z ̌ a l o s t e h$ (CFat 9r); sin b(og)a živoga pridet $i$ svetit se $\mathrm{v}$ rici (CFat 12r); ona žena poide $\mathrm{v}$ dom svoi noseĉ $i$ Božie lice ter ga shrani u svoû skrinu (CFat 22v); ja nisam dostoên da prideši u kuĉu moû (CFat 30r); u treti dan izaiti te zviri morske (CFat 46v); isuh(rst)b u svoei muci otvoril e(st) nam $\cdot \tilde{d} \cdot(=5)$ studenac (CFat 72v)

(92) povit'g(ospod) $b$ 〈v〉 vitliomi u êsalceh' (CBč 28v); B(og)b u êsleh' počiva[šs]e (CBč $28 \mathrm{v}) \| \mid$ i zapov(ê)db b(o)ž'û polagaite v' sr(d)cihb $v(a)$ šihb (CBč 2v); i ako bi v(a)sb sv(ê)tb $i$ v'si s(ve)ti za n' m(o)lili za onoga ki e v' pakli · ne bi ga osl(o)bodili (CBč 66r); Ženom bo $\operatorname{pr}(a) v(a) d n i$ Osip'zatv(o)ren'bê v' tamnici (CBč 69v).

Kako je istaknuto, primjeri zamjenjivanja $v b>u$ u Fatevićevu zborniku često su potvrđeni i u prefiksu $v b-(93)$. Glavnina je primjera s tim prijelazom ponovno potvrđena u tekstu Zrcala duhovnoga. U Berčićevu zborniku zamjena $v b>u$ u prefiksu ostvaruje se samo iznimno (94):

(93) udovice (CFat 38v), uskrsnuti (45r, 47r), uskrsnuce (47r), ustanite (CFat 48v), usta (CFat 51r), uzvišen (CFat 49r), uzvišeniê (CFat 70r), uzvišenu (CFat 70r), ulizal (CFat 53r), ulizoše (CFat 53v), uze (CFat $78 \mathrm{v})$, uzme (CFat 78v)

(94) us'taêše (CBč 12r).

\subsection{Odrazi nosnih samoglasnika}

Nosni su samoglasnici do 17. st., a zapravo i mnogo ranije, izgubljeni u hrvatskome crkvenoslavenskom jeziku i u čakavskome narječju. Na mjestu prednjega nosnog samoglasnika u Berčićevu i Fatevićevu zborniku, kao i općenito u hrvatskim crkvenoslavenskim tekstovima, najčešće dolazi samoglasnik $e$ (95):

(95) ras'peti (CBč 4r, 63v), rasp'etie (CBč 68r), vzeti (CBč 10v), ime (CBč 30r), pameti (CBč 53v, 54r); meso (CFat 4r), knezi (CFat 4v), ime (CFat 10r), pamet (CFat 14v), hoteci $(\mathrm{CFat} 14 \mathrm{v})$, raspeti (CFat $27 \mathrm{v})$

U čakavskome se narječju, međutim, prednji nosni samoglasnik iza $\check{c}, \check{z}$ i $j$ u mnogim primjerima odrazio kao $a$, a u spomenutoj se fonološkoj okolini taj odraz sačuvao do danas u brojnim čakavskim govorima (usp. LISAC 
2009: 17). Jasno je stoga da u tekstovima Berčićeva i Fatevićeva zbornika nalazimo čitav niz potvrda prijelaza $e>a$. Taj je prijelaz u obama zbornicima osobito čest u riječima izvedenim od praslavenskoga korijena *im-koje imaju protetsko $j$ (96) i u riječi językъ (97). Rjeđe je prijelaz $\underset{\varepsilon}{>} a$ posvjedočen u izvedenicama od osnova žęd- (98) i -čęt- (99) u kojima je razmjerno čest i odraz e (100):

(96) êti (CBč 11r), priêl' (CBč 2v, 12v, 27r, 46r), priêlb (CBč 11v, $59 \mathrm{v})$, priêtb (CBč 3r, 52r), priêta (CBč 3r), priêti (CBč 6r, 8r, 19r, 20v, 22v, 40r, 44v), priêli (CBč 6v, 11r), priêše (CBč 6v, 10r, 20r), priêsta (CBč 34r), priêhb (CBč 32r); priêt (CFat 1v), poêt (CFat 10r), priati (CFat 14v, 27r), priêti (CFat 15v), jati (CFat 24r), êti (CFat 24r)

(97) êzici (CBč 8r, 64v, 66r, 68v, 69r), êziče (CBč 13r), êzikoma (CBč 46v), êzič'ni (CBč 68v), êzikb (CBč 70r); êzika (CFat 11v), jazikom (CFat 16r), êzik (CFat 26r, 29r, 29v, 61r, 61v, 75r), êzikom (CFat $29 \mathrm{v}, 75 \mathrm{r})$, zaik (CFat 79v $)^{29}$

(98) žaên (CBč 70v); žaên (CFat 29r), žainoga (CFat 40r)

(99) рос̌a (CBč 3r, 11r, 60r, 64r), počaše (CBč 8v); počaše (CFat 1r), poča $(\mathrm{CFat} 9 \mathrm{v})$, počala (CFat 6r), počati $(\mathrm{CFat} 47 \mathrm{v})$

(100) žedaûc (CBč 18r), žedaûce (CBč 18r, 18v), žeina (CBč 19v), žê̂ (CBč 53v), poče (CBč $8 \mathrm{v}, 9 \mathrm{v}, 12 \mathrm{v}, 13 \mathrm{r}, 15 \mathrm{v}, 35 \mathrm{v}, 57 \mathrm{v}, 65 \mathrm{r})$, počeše (CBč 11v), počela (CBč 28r), početie (CBč 48r), početo (CBč 67r), počeli (CBč 67r); žedam (CFat 4v), žedaše (CFat 4v), začetie (CFat $5 \mathrm{v})$, poče $(\mathrm{CFat} 7 \mathrm{v})$, zače (CFat 10r), žeje (CFat 40r). ${ }^{30}$

Posebno vrijedi istaknuti da do prijelaza $\varepsilon>a$ u Berčićevu i Fatevićevu zborniku može doći i iza glasa $l$ (101). Prijelazu $e>a$ u navedenim je primjerima, dakako, prethodio prijelaz $l>l$, u skupini 'velar $+l$ ' (u navedenim primjerima $k l$ ) na početku korijena riječi ispred prednjih samoglasnika (uključujući, naravno, i e) (usp. npr. primjere gḷêdati, hļı̂b, klı̌šske iz Kukljice; preuzeto iz BENIĆ 2014: 34-35).

${ }^{29} \mathrm{U}$ primjeru zaik naknadno je došlo do premetanja. Inače, oblik s premetanjem i danas se može čuti na otocima pred Zadrom (usp. ŠPRALJA 2016.b: 35).

30 Takvo je stanje svojstveno i drugim hrvatskoglagoljskim tekstovima (usp. CORIN 1991: 246-249; GADŽIJEVA 2012: 124; HCSL 2014: 78-79). Iz navedenih se primjera s osnovom žęd- iz Fatevićeva zbornika dobro vidi da je ostvarivanje refleksa $a$ na mjestu prednjega nosnog samoglasnika, uz ostalo, bitno određeno i glasom koji iza njega dolazi, odnosno jasno se vidi da je veća vjerojatnost za pojavljivanje refleksa $a$ ako za njim slijedi palatal, i to »najpalatalniji« među palatalima, tj. $j$ (usp. također GADŽIJEVA 2012: 126). 
(101) prok’late (CBč 58r); proklati (CFat 18r, 39v), klačeĉi (CFat 76r).

Taj prijelaz i posljedično zamjenjivanje prednjega nosnog samoglasnika glasom $a$ danas je svojstveno isključivo čakavskim otočnim govorima zadarskoga područja (usp. BENIĆ 2013: 25-26 i BENIĆ 2014: 64-65 za Kali i Kukljicu na Ugljanu; ŠPRALJA 2016.a: 38 za Zaglav na Dugome otoku i ŽUŽAK 2016: 28 za Ravu), a čini se da je tako bilo i u vremenu nastanka Berčićeva i Fatevićeva zbornika. Naime, prijelaz $e_{>}>$a iza l, osim u Fatevićevu i Berčićevu zborniku, potvrđen je i u drugim neliturgijskim glagoljskim zbornicima čiji se nastanak vezuje uz zadarsko područje, primjerice u Ivančićevu zborniku (102) i u Klimantovićevu zborniku I. (103), kao i u isključivo čakavskim tekstovima nastalima na zadarskome području u 16., 17. i 18. st.. ${ }^{31}$ U drugim pak zbornicima (npr. Petrinićevu, Tkonskom) takvi primjeri nisu zabilježeni, tj. u njima na mjestu prednjega nosnog samoglasnika u primjerima navedenoga tipa redovito nalazimo $e$.

(102) klat'stva (CIvan 13v), klat've (CIvan 34v), prokla (CIvan 48v), poklaknuti (CIvan 95r)

(103) poklaknet' (RitKlim 55), p'roklati (RitKlim 156), proklats 'tvo (RitKlim 401).

Prijelaza u $e$, doduše, ima i u Fatevićevu i, osobito, Berčićevu zborniku (104), no takvo stanje ne iznenađuje. Naime, upravo kolebanje u bilježenju odraza prednjega nosnog samoglasnika u spomenutome položaju pokazuje da su pisari bili svjesni snažne dijalektalne obojenosti primjera tipa poklaknuti i proklati - poglavito s obzirom na činjenicu da analognih primjera nema u hrvatskim crkvenoslavenskim tekstovima - pa su ponegdje bilježili uobičajenije i normi bliže primjere tipa pokleknuti, prokleti. Ipak, i povremeni, pa čak i sasvim rijetko potvrđeni prijelazi $e>a$ iza $l$ pokazuju da je u pisarevu govoru ili području na kojem je zbornik nastao promjena postojala.

(104) prokleti (CFat 31r, 50r, 58v), prokletimi (CFat 38r), pokleknu (CFat 23v); proklet' (CBč 1r, 52v, 60v), prokleti (CBč 2v, 21r, 43r, 58v), prokletihb (CBč 5r), klet'vi (CBč 14r), klet've (CBč 19v), klet'vu $(\mathrm{CBč} \mathrm{19v,} \mathrm{20v),} \mathrm{prokleto}(\mathrm{CBč} \mathrm{58v).}$

Stražnji se nosni samoglasnik, kako je uobičajeno u hrvatskim crkvenoslavenskim tekstovima, odrazio kao $u(105)$ :

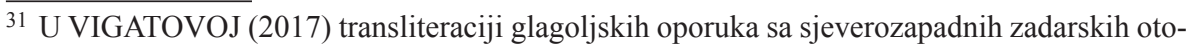
ka iz 16., 17. i 18. st. pronašli smo primjer proklat, a sličnih je primjera mnogo i u glagoljskome priručniku za svećenike koji je u 15. st. nastao na zadarskome otočnom području (usp. PETEŠIĆ 2017). 
(105) bludb (CBč 42r, 49r), bluda (CBč 18v), iĉuĉi (CBč 14r), ruke (CBč 63v), suditi (CBč 8v, 46r), buduĉ' (CBč 76v), zubi (CBč 14r); budi (CFat 1r), rekuĉi (CFat 2r), muž (CFat 5r), ruku (CFat 7r), suditi (CFat 14r), isplačut (CFat 14v), utrobu (CFat 14v), poginula (CFat 15r), tugu (CFat 22v), spavâu (CFat 26v), blud (CFat 26v), mudrost (CFat 32r), priobrnuti (CFat 34r), pobignuti (CFat 35v), susedi (CFat 37r).

Primjer uskrsnoti koji je potvrđen u Fatevićevu zborniku (47r) očito treba tumačiti kao pisarsku pogrešku s obzirom na to da je glagol više puta potvrđen $\mathrm{u}$ obliku uskrsnuti (CFat 45r, 47r, 47v, 48r) te da glagoli iste vrste redovito imaju sufiks -nu- (otrinuti CFat 2r, potegnuti CFat 64r, vzdvignuti CFat 76r itd.). Vrijedi istaknuti i to da je u Berčićevu zborniku dvaput potvrđen akuzativni oblik sobotu 'subotu' $(15 \mathrm{v}, 49 \mathrm{r})$. Po svoj prilici o u tim primjerima ne treba objašnjavati prijelazom $Q>o-$ koji inače na čakavskomu području nije sasvim nepoznat (usp. LISAC 2009) - nego treba pretpostaviti da je oblik postao od latinskoga sr. mn. sabbáta, a ne od oblika sambáta, dakle s $m$ ispred labijala (s posljedičnim prijelazom $s a m b->s Q b-$ ), koji je bio karakterističan za balkanski latinitet (usp. SKOK 1973: 299). ${ }^{32}$

\subsection{Odraz jeryja}

Osim nosnih samoglasnika, u Berčićevu i Fatevićevu zborniku očekivano se ne ostvaruje ni starocrkvenoslavenski glas y (jery), koji se »izjednačio $\mathrm{s}$ fonemom / $i$ / već na početku hrvatskoga crkvenoslavenskog razdoblja, najkasnije početkom 12. st.«(106) (usp. HCSL 2014: 79): ${ }^{33}$

(106) dimb (CBč 32v, 33r), sinove (CBč 4v, 17v, 62v), sipati (CBč 24v); biti (CFat 35r, 35v, 37r, 45v, 36r), sin (CFat 59r, 76v), misliti (CFat 56r, 70r).

\subsection{Prijeglas}

Prijeglas se u Berčićevu i Fatevićevu zborniku provodi uglavnom dosljedno pa se samoglasnik $o$ samo iznimno ostvaruje iza palatalnih suglasnika, tj.

\footnotetext{
32 Oblici izvedeni od latinskoga sabbáta nisu nepoznati ni u suvremenim govorima srednjočakavskoga dijalekta, uključujući, dakako, i čakavske govore zadarskoga područja. Oblik soböta potvrđen je, primjerice, na Ravi (usp. BOŽIN 2017), u Kukljici BENIĆ (2014) bilježi saböta, a isti je oblik prisutan i u velološinjskome govoru (usp. BODOR 2013). U okviru istoga dijalekta Sanja VULIĆ (2008) bilježi söbota u govoru Turkovića na ogulinsko-modruškome području.

${ }^{33} \mathrm{O}$ neutralizaciji $y>i$ i posljedicama te neutralizacije v. i u poglavlju 4.13. Usp. također HCSL 2014: 82-83.
} 
u toj se okolini većinom zamjenjuje samoglasnikom $e$. Smjena $o \sim e$ vidljiva je, primjerice, u nastavcima instrumentala jednine i dativa množine imenica muškoga i srednjega roda $o$-osnova i jo-osnova (107):

(107) narodom' (CBč 1v), postom' (CBč 2v), rodom' (CBč 3r), telom' (CBč 11r), umoms (CBč 12r), lûbodêinikom' (CBč 18v); zakonom (CFat 4v), sinom (CFat 5r, 10r), šcapom (CFat 6v), grihom (CFat 8r), glasom (CFat 9r), bogom (CFat 9v), vratom (CFat 11v), telom (CFat $13 \mathrm{v}, 16 \mathrm{r}, 21 \mathrm{v}) \|$ mečems (CBč 10r), poč 'ten'em' (CBč 11v), veseliem' (CBč 17r), kameniemb (CBč 19r), og 'nemb (CBč 20r), plačem' (CBč 29v); plačem (CFat 6r, 32r), cvicem (CFat 7v), ognem (CFat 14r, 78r), činenem (CFat 15r), križem (CFat 16r, 27r, 78r), arvačem (CFat 17r), slišanem (CFat 29v), mužem (CFat 37r), nepriêtelem (CFat 56v), pokaêniem (CFat 74v), kopiem (CFat 75v).

U većini se hrvatskih crkvenoslavenskih tekstova smjena $o \sim e$ može vidjeti i u nastavku instrumentala jednine imenica $a$-osnova i ja-osnova. Tako je i u Berčićevu zborniku u kojem se nastavak -oû dodaje na tvrde, a nastavak -eû na meke osnove (108). U Fatevićevu zborniku u ja-osnovama redovit je nastavak -om, preuzet iz o-promjene, koji je vrlo čest i u $a$-osnovama, ${ }^{34}$ dok crkvenoslavenski nastavak -êu nije potvrđen u imeničkoj sklonidbi. ${ }^{35}$ Opreka -ôे/-êu vidljiva je, međutim, u instrumentalu jednine neličnih zamjenica ${ }^{36} \mathrm{i}$ pridjeva ženskoga roda (109):

(108) m(o)litvoû (CBč 2r, 3r), družinoû (CBč 17r), t'moû (CBč 18r), dêvôu (CBč 19r), vodoû (CBč 31v) \| volêे (CBč 20v, 23r)

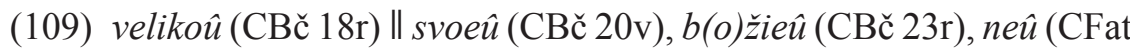
$9 \mathrm{v})$, vašeû (CFat 32r).

Kao palatali ponašaju se i dentali $c$ i $z$ nastali trećom palatalizacijom (usp. HCSL 2014: 84) te sonant $r$ (110):

\footnotetext{
${ }^{34}$ Usp. primjere dušom (CFat 21v), teškoĉom (CFat 29r) za ja-osnove. Navodimo i primjere vodom (CFat 12v), glavom (CFat 13r), ženom (CFat 23v, 28r, 37r), nevestom (CFat 37r), rukom (CFat 46v) za $a$-osnove.

${ }^{35} \mathrm{U}$ tvrdoj se promjeni, uz oblike sa spomenutim preuzetim nastavkom -om, ostvaruju i oblici s

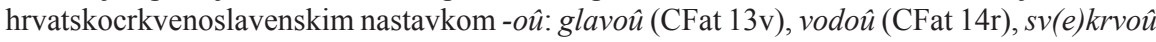
(CFat 37r).

${ }^{36}$ U ličnim zamjenicama, ne računajući zamjenice za treće lice, $u$ instrumentalu jednine nema opreke jer sve imaju tvrdu osnovu: soboû (CBč 19r, 44v), toboû (CBč 63v, 67r); mnô̂ (CFat 21r). Zamjenice za treće lice izražavaju se »oblicima pokazne zamjenice on, ona, ono, a u kosim padežima oblicima anaforičke zamjenice $i$, ja, je« (HCSL 2014: 133) (s eventualnim predmetkom $n$-) pa se i sklanjaju kao nelične zamjenice.
} 
(110) srcemb (CBč 2v), licemb (CBč 12r), priš'l'cemb (CBč 16v), sud'cemb (CBč 18v), knezem' (CBč 38v), ol 'taremb (CBč 5r), c(êsa)remb (CBč 63v); suncem (CFat 7v), licem (CFat 22v, 23v, 31r, 37r), vencem (CFat 24v, 29v), ocem (CFat 30v, 37r), srcem (CFat 31v, 32r), sarcem (CFat 66r, 66v, 67r), sucem (CFat 66v), kupcem (CFat 79v), vitezema (CFat 24r), pastirem (CFat 25v), stvarem (CFat 36v).

Opreka $o \sim e$ u obama je zbornicima dobro očuvana u sklonidbi zamjenica i pridjeva. Vidljiva je u genitivu i akuzativu ${ }^{37}$ jednine muškoga i srednjega roda (111), u dativu i lokativu jednine muškoga i srednjega roda (112) te u dativu i lokativu jednine ženskoga roda (113):

(111) nied'noga (CBč 2r), nikoga (CBč 8v), vsakoga (CBč 10r), prečistoga (CBč 13v); velikoga (CFat 5r), večnoga (CFat 9r), človičaskoga (CFat 16v), nagoga (CFat 40r) II nega (CBč 1r, 6v, 9v) isk'rnega (CBč 6v), tuega (CBč 7r), našega (CBč 77v); minuvšega (CFat 5v), liplega (CFat 22v), svemoguĉega (CFat 28r)

(112) tom' (CBč 3r), b(la)ž(e)nomu (CBč 3r), smr 'tnom' (CBč 5r), onomu (CBč 11v), prelutomu (CBč 14v), nêkotêromu (CBč 39v), gr'domu (CBč 62v), starom' (CBč 76r) II iskr 'nemu (CBč 6r), vašemu (CBč 19r), bož'em (CBč 29r), sud'nemb (CBč 15v), svoemb (CBč 23r), с̌етu $(\mathrm{CBč} 59 \mathrm{v})$

(113) onoi (CBč 9r), prev(e)likoi (CBč 12v), pres'lat'koi (CBč 13v), čis 'toi (CBč 19r); dragoi (CFat 7r), slavnoi (CFat 8v), židovskoi (CFat 15r), toi (CFat 27v) \|| nei (CBč 4v), b(o)ž'ei (CBč 9r), vašei (CBč 40r), tvoei (CBč 54r, 59v); današnei (CFat 2r), svoei (CFat 10r, 72r), tuei (CFat 18v).

\subsection{Zamjena $r a>r e$}

Od ostalih samoglasničkih promjena svakako treba spomenuti nekoliko primjera prijelaza slijeda ra u re u Fatevićevu zborniku u oblicima glagola rasti i krasti i njihovim izvedenicama (114):

(114) zreste (CFat 13v), restu (CFat 61r), ukredut (CFat 30v).

Ta je fonološka izoglosa u prošlosti očito povezivala (jugoistočnu) čakavštinu sa zapadnom štokavštinom. Na to ukazuje suvremeno stanje u organ-

\footnotetext{
${ }^{37} \mathrm{U}$ akuzativu samo uz zamjenice i pridjeve koji stoje uz imenice muškoga roda koje označavaju što živo.
} 
skim idiomima - spomenuta je promjena, naime, i danas uobičajena (osobito) u jugoistočnim čakavskim govorima (usp. LISAC 2009: 159) te u zapadnome dijalektu štokavskoga narječja (usp. LISAC 2003: 52) - ali i stanje u starijim tekstovima, uključujući i one koji su pretežno pisani crkvenoslavenskim jezikom u koji su prodirali elementi narodnoga jezika. Prijelaz $r a>r e$ potvrđen je tako u Hvalovu zborniku (npr. ukredutb Hz 46, ukredešy Hz 234v), spomeniku bosanske redakcije crkvenoslavenskoga jezika iz 1404. g. koji je nastao na zapadnoštokavskome području (usp. GALIĆ 2016), te u zborničkim neliturgijskim tekstovima koji se vezuju uz dalmatinsko čakavsko područje, primjerice u Ivančićevu zborniku (npr. reste CIvan $68 \mathrm{v}$, resti CIvan $72 \mathrm{v}$ ) ili u Klimantovićevu zborniku (npr. vzrêstet' ${ }^{38}$ RitKlim 56). U Berčićevu zborniku prijelaz $r a>$ re nije potvrđen, no takvo što i nije sasvim iznenađujuće s obzirom na činjenicu da je i u znatno mlađem Fatevićevu zborniku mnogo više primjera u kojima do prijelaza nije došlo, a tako je i u drugim spomenutim rukopisima sa zadarskoga područja. Primjera s prijelazom nema ni u glagoljskome priručniku za svećenike sa zadarskoga otočnog područja koji je po prilici nastao u isto vrijeme kada i Berčićev zbornik (usp. PETEŠIĆ 2017) pa nije isključeno da su pisari svjesno izbjegavali takve oblike jer su ih smatrali izrazitim dijalektizmima.

\subsection{Ispadanje samoglasnika}

Ispadanja samoglasnika ni u jednome ni u drugome zborniku nisu odveć česta. Primjeri sinkopiranja, tj. ispadanja samoglasnika u sredini riječi (usp. MIHALJEVIĆ 2002: 15), potvrđeni su u obama zbornicima, i to osobito uz sonant $r$, koji ispadanjem susjednoga samoglasnika preuzima samoglasničku ulogu, kako se vidi u (115). Takva su ispadanja dobro potvrđena i u drugim hrvatskoglagoljskim tekstovima (usp. GRABAR 1967: 121; DAMJANOVIĆ 2008: 296; MIHALJEVIĆ 2011: 131; LOZIĆ KNEZOVIĆ 2016).

(115) skrvena (CBč 1r), skr'vena (CBč 1r), grg(u)rb (CBč 4v, 53r, 71v), grgurb (CBč 61r), brnar'db (CBč 4r, 53r); Brnardo (CFat 2v, 3v, 7r, 36v, 73r), prgatoriah (CFat 6r), prnesite (CFat 13v), prgatorii (CFat 50r, 52v, 53v, 54r, 54v), prgatoriê (CFat 50r, 53r, 54v, 68v), prgatoriev (CFat 52v), prgatorij (CFat $65 \mathrm{v})$, sakrštan (CFat 52v), przenciû (CFat 48r), grgur (CFat 4r, 55r, 56r, 63v, 64r).

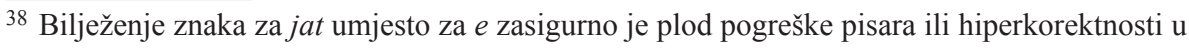
bilježenju grafema za jat.
} 
S druge strane, razmjerno rijetki primjeri afereze, tj. ispadanja samoglasnika na apsolutnome početku riječi (usp. MIHALJEVIĆ 2002: 14), potvrđeni su samo u tekstovima Fatevićeva zbornika i predstavljaju očit utjecaj narodnoga jezika (116):

(116) vom (CFat 15v), noi (CFat 19r, 51r), vom (CFat 33r), nom (CFat 35r), vanjele (CFat 16r), vanjelist (CFat 16r), sukrstom (CFat 35r), Sukrst (CFat 49v).

\subsection{Slogotvorni sonant $r$}

Kako je poznato, sonanti $r$ i $l$ još su u praslavenskome jeziku mogli preuzeti samoglasničku ulogu (usp. MIHALJEVIĆ 2002: 94), a u toj su ulozi česti i u hrvatskoglagoljskim tekstovima, nerijetko, kako smo već istaknuli, praćeni znakovima za poluglas. U Berčićevu zborniku po prilici je jednak broj primjera u kojima se uz slogotvorno $r$ ostvaruje apostrof kao znak za jer i primjera u kojima uz slogotvorno $r$ nema popratnih znakova, kao u (117), što pokazuje da popratni apostrof nema nikakvu glasovnu vrijednost, nego se nesustavno upotrebljava kao oznaka slogotvornosti sonanta. Kada se ostvaruje, znak za jer rjeđe stoji ispred slogotvornoga $r$ (118), a znatno se češće bilježi iza njega (119):

(117) držeĉi (CBč 19r), održimi (CBč 72r, 73v), vs'krsnet' (CBč 2r), krsbtênska (CBč 76r), krstênb (CBč 9r, 71v), krst(ite)l' (CBč 17r), krsvskrsnuti (CBč 63v), krst(i)lı (CBč 63v), krvb (CBč 16v, 48r), semrti (CBč 65r), mrtvihs (CBč 46v), prvi (CBč 3v, 15v, 54r), naiprvom' (CBč 13v), prvoga (CBč 13v), prve (CBč 16v), prvihb (CBč 38r), srcih' (CBč 5r), srce (CBč 13r, 27r), trne (CBč 20v), trn'ii (CBč 63v), vrh' (CBč 58v, 59r), trs 'tiû (CBč 13v), trstb (CBč 20v, 42r), žrt'nicu (CBč 55r)

(118) pred'ržaše (CBč 18v), d'ržaše (CBč 70v), k'rvava (CBč 15v), k'rv' (CBč 51v, 55v), sm'rti (CBč 26v, 48v, 51r), m'rtvu (CBč 38v)

(119) dr'žati (CBč 7v, 19r), dr'žeĉe (CBč 16v, 17r), dr'že (CBč 18r), $k r$ 'st'ênb (CBč 66v), kr'sta (CBč 71v), vskr'sni (CBč 72r), kr 'st'ên' (CBč 75r), kr'vb (CBč 17v, 45r, 75v), kr'v'û (CBč 19v), kr'viû (CBč 47r), mr'mlivi (CBč 54v), mr'tva (CBč 4v), smr 'tnom' (CBč 5r), semr'tnago (CBč 8r), semr'tnêi (CBč 19v), semr't' (CBč 20r), $m r$ 'tvago (CBč 20v, 31r), pr'vo (CBč 6r, 27v, 52v, 53v, 54r, 64r), pr'vi (CBč 14v, 41v, 48r), pr'vin (CBč 16v), pr'vinu (CBč 19v), naipr'vo (CBč 21v), pr'vu (CBč 57v), sr'ca (CBč 2r), sr'ci (CBč $7 \mathrm{v})$, tr'nov' (CBč 20v, 26v), vr'ha (CBč 16r). 
Za razliku od stanja u Berčićevu zborniku, uz slogotvorno se $r$ u Fatevićevu zborniku nikada ne ostvaruju jerovi, a u većini se potvrda, s izuzetkom onih u tekstu Zrcala duhovnoga, uz $r$ ne ostvaruje ni popratni samoglasnik (120):

(120) četvrti (CFat 33v, 41v, 46v, 49r), četvrtak (CFat 32v), črv (CFat 77r), $k r v(\mathrm{CFat} \mathrm{3v}, 4 \mathrm{v}, 14 \mathrm{r}, 27 \mathrm{r}, 72 \mathrm{v})$, drži (CFat 8r, 38v, 58r), držan (CFat 43r), vzdržati (CFat 79v), krsçanin (CFat 33v, 34v, 35r, 44v, 66r), krščen (CFat 20r), krščeno (CFat 34v), krstitel (CFat 5v, 8r), uskrsnuti (CFat 45r, 47r, 48r), uskrsnuce (CFat 47r), krvô̂ (CFat 37r), milosrdie (CFat 9r, 9v, 19v, 65r), milosrdni (CFat 10v), mrmnati (CFat $33 \mathrm{v})$, srdit (CFat $16 \mathrm{v}, 17 \mathrm{v})$, prvi (CFat 30v, 41v, 46r, 65r), naiprvi (CFat 7r), rasrdit (CFat 9r), rasrdi (CFat 9r, 11v, 31r, 33r, 42v), rasrdiše (CFat 11r), smrt (CFat 9r, 13r, 22v, 25r, 60r, 62r, 72r), smrtne (CFat 27v), srca (CFat 10v, 22v, 36v, 37r, 37v), srcih (CFat 19r), srcem (CFat 31v, 32r), srčene (CFat 71r), trs (CFat 4v, 25v), trsu (CFat $25 \mathrm{v})$, vrh $(\mathrm{CFat} 7 \mathrm{v}, 19 \mathrm{v})$, vrha $(\mathrm{CFat} 11 \mathrm{v})$, zrcalo (CFat $38 \mathrm{v})$.

U prijepisu Zrcala duhovnoga uz $r$ se razmjerno često ostvaruje popratni samoglasnik. Takvih primjera ima i u ostalim zborničkim tekstovima, ali su oni u njima znatno rjeđi. U golemoj se većini primjera radi o popratnome samoglasniku $a$ (121), a vrlo rijetko o samoglasniku $e$ (122):

(121) arvačem (CFat 17r), arvali (CFat 18r), čarvi (CFat 30v), četvartom (CFat 54r), čarne (CFat 30r, 60v), daržati (CFat 58v), isukarst (CFat 69v, 70r), isukarstu (CFat 64r, 70v), karpa (CFat 50v), karscianske (CFat 66r), karstjanin (CFat 66r), karv (CFat 30r, 65v), karviû (CFat 65v), marzak (CFat 31v), marmorane (CFat 46v), martvi (CFat 68v), martvoga (CFat 50v, 52r, 55r), pomarče (CFat 30r), parvi (CFat 67v), parvoga (CFat 59v), sarce (CFat 65v), sarcem (CFat 66r, 66v, 67r), smart (CFat 31r, 31v, 56r, 61v, 64r, 66v, 72r), smartno (CFat 60r), tarsa (CFat 25r), umarli (CFat 61v, 65r), varhu (CFat 65v), zvarhu (CFat 59r), zarcalo (CFat 44r)

(122) černe (CFat 30r), sercem (CFat 72r).

Postojanje popratnoga samoglasnika nije tipično za hrvatskoglagoljske zborničke tekstove do polovice 16. st. u kojima se slogotvorno $r »$ dosljedno bilježi bez popratnoga samoglasnika« (DAMJANOVIĆ 2008: 66) te predstavlja očit utjecaj narodnoga (čakavskoga) jezika. Potvrđuje to i činjenica da se u čakavskim tekstovima nastalim na zadarskome području u otprilike istome razdoblju - kakvi su, primjerice, tekstovi glagoljskih oporuka sa sjeverozapadnih zadarskih otoka nastali od kraja 16. do 18. st. - oblici u kojima se uz 
$r$ ostvaruje popratni samoglasnik smjenjuju s oblicima u kojima popratnoga samoglasnika nema, pri čemu prvi pretežu (usp. VIGATO 2017). ${ }^{39}$

\subsection{Slogotvorni sonant $l$}

Uz slovo 历h kojim se u hrvatskoglagoljskim tekstovima označava slogotvorni sonant $l$ u Berčićevu se zborniku uglavnom redovito bilježi znak za jer, najčešće apostrof, koji u glavnini primjera dolazi iza $l$, kao u (123). Potvrđene su, međutim, i druge mogućnosti. U dijelu se primjera, naime, uz slogotvorno $l$ ne bilježi znak za jer (124), u dijelu primjera znak za jer dolazi samo ispred $l(125)$, a iznimno su rijetki i primjeri sa znakom za jer ispred i iza $l$, kao u (126):

(123) dl'gi (CBč 5v), dl'ge (CBč 5v, 6r, 7v), dl'gu (CBč 52r), dl'žnikomb (CBč 6r, 7v), hl'mi (CBč 62v), uml'knu (CBč 37r), pl'nb (CBč 68v), pl'na (CBč 17v, 27r, 67r, 71v), pl'nu (CBč 8r), napl'nena (CBč 60v), is 'pl'ni (CBč 36v), kl'neĉi (CBč 16r), prokl'ne (CBč 60r), pl'kb (CBč 2r, 45r, 77v), pl'ka (CBč 21r, 47r, 75v), upl'ti (CBč 28r), pl'tb (CBč 8r, 10r, 16v, 37v, 40r, 54v, 70r), pl 't' (CBč 34r), pl'ti (CBč 8r), sl'nce (CBč 16r, 16v), sl'n' 'čnomb (CBč 15r), sl'ze (CBč 20v), sl'zami (CBč 24v, 31v, 32v, 73r), stl'pb (CBč 17r, 38v), stl'm(a)č(e)nie (CBč 4r), vl'h'vomb (CBč 75v), svl'koše (CBč 20v), vl'ki (CBč 38r), vl'čicah' (CBč 63v), žl' 'či (CBč 17r, 26r)

(124) dlžnikomb (CBč 5v), isplneniê (CBč 9r), klnut' (CBč 14v), klni (CBč 52r), slzami (CBč 12r), proslzi (CBč 69r), v'pltiti (CBč 19r), v'pltih' (CBč 20v), pltb (CBč 19r, 43r), sln'ce (CBč 13r, 19r, 19v, $20 \mathrm{v}, 23 \mathrm{r}, 44 \mathrm{v}, 72 \mathrm{v}, 73 \mathrm{v}), \sin c a(19 \mathrm{r}, 26 \mathrm{r}, 31 \mathrm{v}, 47 \mathrm{v})$

(125) d'lžan' (CBč 9v), d'lžni (CBč 19v), d'l'gota (CBč 13v), p'lkb (CBč $76 \mathrm{v})$, s'ln'ce (CBč 17v)

(126) k'l'nu (CBč 3v), v'l'koše (CBč 11r) (110).

Lateralni je suglasnik $l \mathrm{u}$ svega nekoliko primjera navedenih u (127) pod utjecajem stanja u narodnome jeziku zamijenjen samoglasnikom $u$, a u jednome mu je primjeru isti samoglasnik samo pridodan pa se na mjestu sonanta $l$ ostvaruje slijed $l u$, kako se može vidjeti u (128):

${ }^{39}$ Lisac (2009: 100) spominje niz srednjočakavskih punktova u kojima se i danas ostvaruju popratni samoglasnici $e$ ili $a$ uz $r$. Od punktova sa zadarskoga područja navodi Iž i Olib. U glavnini suvremenih čakavskih otočnih govora zadarskoga područja uz $r$ ipak ne dolazi popratni samoglasnik. Znakovito je, međutim, da se popratni samoglasnik (i to redovito $a$ ) može pojaviti u primjerima u kojima $r$ dolazi na apsolutnome početku riječi: ärvati se, àrpa, Ärtak (top.), Artît' (top.) (usp. ŠPRALJA 2016.b: 11; BENIĆ 2014: 66). 
(127) dugovan'e (CBč 35r), suzi (CBč 12r), stupu (CBč 20v), žuči (CBč $26 \mathrm{v})$

(128) d'lugb (CBč 65r).

Sasvim je drugačija situacija u Fatevićevu zborniku u kojem je slogotvorno $l \mathrm{u}$ golemoj većini primjera zamijenjeno $\mathrm{s} u(129)$. Znatno je manje potvrda zamjenjivanja slogotvornoga $l \mathrm{~s} u l(130)$, a samo je u jednome primjeru zabilježeno čuvanje slogotvornoga $l$, i to, dakako, bez bilježenja popratnoga znaka za jer (131):

(129) pun (CFat $14 \mathrm{v}, 15 \mathrm{v}, 62 \mathrm{r})$, puno (CFat 55r, 63r), prepun (CFat 60v), napunite (CFat 14v), napunena (CFat 7r), ispuniti (CFat 16v), ispuneno (CFat 73v, 80r), dug (CFat 64r), duga (CFat 72r), dugo (CFat 10r, 20r), dubinu (CFat 16r), duboku (CFat 72r), vdubleni (CFat $34 \mathrm{v})$, sunce (CFat 2r, 13r, 22v, 79r), sužučiû (CFat 24v), prokunu (CFat 12v, 74r), kune (CFat 25r), kuni (CFat 80r), stupa (CFat 73r), dužni (CFat 14v), puk (CFat 20v, 21v, 22v, 33r, 53v, 67v, 78r), puče (CFat 40r), putiû (CFat 10r, 26r), put (CFat 25r), kune (CFat 25r), suz (CFat 26r, 57r, 61r), suze (CFat 30r), puh (CFat 26r, 26v), tumačene (CFat 44r), stumačiti (CFat 55r), mučati (CFat 48r)

(130) pult (CFat 2v, 3r, 3v), pulti (CFat 2v), dulgovaniê (CFat 33v), sulze (CFat 34r), udulbena (CFat 34v), vdulbena (CFat 34r, 34v), mulnie (CFat 17v), stulpa (CFat 19v), stulpi (CFat 73r)

(131) vdlbena (CFat 34v).

Opisano stanje u Fatevićevu zborniku poprilično se razlikuje od stanja u hrvatskoglagoljskim liturgijskim spomenicima, ali i u zbornicima neliturgijskoga štiva (usp. MILČETIĆ 1890: 53; GRABAR 1967: 121; HERCIGONJA 1970: 190; DAMJANOVIĆ 2008: 294) u kojima su primjeri zamjenjivanja slogotvornoga $l$ samo sporadični (usp. DAMJANOVIĆ 2008: 290; HCSL 2014: 69). S druge strane, prevladavajuće zamjenjivanje slogotvornoga $l \mathrm{~s} u$ (odnosno $u l$ ) u Fatevićevu zborniku i postojanje znatnih razlika u odnosu na ostale hrvatskoglagoljske zborničke tekstove ipak ne čudi s obzirom na to da se radi o zborniku koji nastao krajem drugoga desetljeća 17. st., čak tri stoljeća nakon tekstova u kojima su zabilježene prve zamjene slogotvornoga $l \mathrm{~s} u$ (usp. MATASOVIĆ 2008: 155; LUKEŽIĆ 2012: 175).

\subsection{Smjenjivanje $f \sim p$}

Fonem /f/, bilježen grafemom $\Phi, \mathrm{u}$ hrvatskoglagoljskim se tekstovima do sredine 14. st. ostvaruje isključivo u riječima stranoga podrijetla, a i u njima 
se kao strani element nerijetko zamjenjuje artikulacijski bliskim glasovima $p$ ili, rjeđe, $v$ (usp. HCSL 2014: 65-66). Smjenjivanje znakova za foneme $/ f /$ i, obično, /p/ u glagoljskim je tekstovima nastavljeno i u kasnijim stoljećima (usp. DAMJANOVIĆ 2008: 79; BLAŽEVIĆ KREZIĆ 2016: 250) u kojima se znak $\Phi$, osim u stranim, počeo pojavljivati i u domaćim riječima, obično na mjestu suglasničke skupine $p v$ u oblicima glagola upvatilufati.

U Berčićevu se i u Fatevićevu zborniku fonem /f/ ostvaruje razmjerno često, osobito u riječima i imenima stranoga podrijetla (132):

(132) herofimi (CBč 5v, 72v), herofimb (CBč 18v), serafimi (CBč 5v, 17r), oficii (CBč 8r), oficiê (CBč 8v), kun'far'tati (CBč 14v), frat'ri $(\mathrm{CBč} 16 \mathrm{v}, 17 \mathrm{v})$, ponifata $(\mathrm{CBč} 22 \mathrm{r})$, bonifata $(\mathrm{CBč} 24 \mathrm{v})$, fran 'čis 'ko (CBč 29r), rufiên' (CBč 51r); alefa (CFat 5v), šerafim (CFat 3r), fruštaûci (CFat 24v), faliti (CFat 34v), defeti (CFat 36v) fratri (CFat 38r, 64v), febrara (CFat 44r), frančiska (CFat 44v), kafernaumu (CFat 44v), luncifer (CFat 44v), ezofatovi (CFat 48r), suficijociû (CFat 48v), oficii (CFat 52v, 75v), filozof (CFat 55r), epifaniu (CFat 58v), epifanii (CFat 58v, 59r), afecioni (CFat 61r), kumforti (CFat 61r), infortili (CFat 63r), profecie (CFat 63v), fundament (CFat 64v), franciên (CFat 78r).

Zanimljiv je primjer efifanie (CFat 74r) iz Fatevićeva zbornika u kojem na mjestu latinskoga $p$ dolazi $f$. Taj je primjer zabilježen i u drugim hrvatskoglagoljskim tekstovima (usp. HCSL 2014: 66). Zamjene $f>p$ u Fatevićevu zborniku prilično su rijetke, a vrijedi istaknuti da su gotovo svi zabilježeni primjeri pronađeni u prvome dijelu zbornika u kojem su, kako smo već istaknuli, starija jezična obilježja znatnije zastupljena nego u drugome dijelu (133). U tome je smislu vrijedno istaknuti i to da u drugome dijelu zbornika, za razliku od prvoga, u Kajfinu imenu nema zamjenjivanja fonema $/ f /$ fonemom $/ p /$ (kaife CFat 73r, kaifini CFat 73r). U jednome je primjeru (vriške CFat 61r) u Fatevićevu zborniku $f$ zamijenjeno labiodentalnim sonantom $v$. Primjera zamjenjivanja $f \mathrm{~s}$ $p$ ima, naravno, i u raznim tekstovima Berčićeva zbornika (134):

(133) blaspimaju (CFat 6v), jepesi (CFat 20r), kaêpu (CFat 23v, 24r), kaêpi (CFat $24 \mathrm{v})$, paraona (CFat $78 \mathrm{v})$

(134) ponistra (CBč 8r), osopat (CBč 15r), šerapimi (CBč 30r), pilipb (CBč 63r), serapimi (CBč 72v).

U domaćim je riječima fonem /f/u Fatevićevu zborniku redovit u oblicima glagola ufati i njegovim izvedenicama (135), a pritom nisu zabilježeni primjeri s izvornom skupinom $p v$. Drugačije je stanje u Berčićevu zborniku, u kojem 
prevladavaju oblici i izvedenice navedenoga glagola sa skupinom $p v$ (136) koja se samo iznimno zamjenjuje fonemom /f/ (137):

(135) ufaûcih (CFat 2v), ufaimo (CFat 2v), ufaniê (CFat 33r), ufanie (CFat 34v, 61r, 65r, 66v), ufaniû (CFat 65r, 68v)

(136) up'vano $(\mathrm{CBč} \mathrm{7v),} \mathrm{up'van'e} \mathrm{(CBč} \mathrm{9v),} \mathrm{up'vâu} \mathrm{(CBč} \mathrm{12v),} \mathrm{up'vani}$ (CBč 12v), up'vaniê (CBč 23v, 65r), up'van 'ê (CBč 66r), up'vane (CBč 77v), upvan'e (CBč 65v, 66r)

(137) ufan'e (CBč 26r, 26v), ufanie (CBč 71v).

Fonem /f/ u Fatevićevu zborniku potvrđen je i na mjestu suglasničke skupine $h v$ (fala CFat $43 \mathrm{v}$ ), ali ne u zborničkome tekstu, nego u potpisima pakoštanskih svećenika don Mikule Pilicarića Juričića i don Tome Bungura iz 1636., odnosno 1685. g., koji se, kako smo istaknuli, naknadno dopisani na prazne stranice zbornika. ${ }^{40} \mathrm{U}$ ostalim se primjerima skupina $h v$ uvijek čuva (138). U Berčićevu zborniku posvjedočeni su isključivo oblici sa skupinom $h v(139)$ :

(138) hvaleci (CFat 1v), hvaleniê (CFat 1v), hvalu (CFat 5r), pohvalene (CFat 7r), hvalenoga (CFat 7r), hvalet (CFat 10v), pohvaleni (CFat 36r), zahvali (CFat 43r), hvala (CFat 43v), pohvalen (CFat 59r), zahvaluû (CFat 67r), hvaliti (CFat 70r)

(139) zahvalui (CBč 53v), s'hvalû (CBč 61v), pohvaliti (CBč 76v).

\subsection{Smjenjivanje $v \sim b$ (vitacizam)}

U Berčićevu zborniku u posuđenicama ima primjera vitacizma, tj. preuzimanja grčkoga glasa beta »prema srednjovjekovnom grčkom izgovoru kao $v \ll$ (140) (MIHALJEVIĆ 1997: 120). Bilježenje grafema In na mjestu bete nije, međutim, dosljedno pa u mnogim primjerima na mjestu toga glasa dolazi grafem 巴 (141). U Fatevićevu zborniku primjeri vitacizma nisu potvrđeni.

(140) saovaot' (CBč 17v), vitl(ê)omê (CBč 28v), vit'l(ê)omi (CBč 28v), avram'li (CBč 30r), av'ramu (CBč 41v), avraam' (CBč 41v, 42r), avraama (CBč 42v), avelb (CBč 42v), tiv'ra (CBč 47v), zavêdei (CBč 52v), elisav(e)ta (CBč 52v)

(141) babilon (CBč 16r), ab'raamb (CBč 17v), abrama (CBč 77v), gabriels (CBč 17v), gabriela (CBč 19r, 66v).

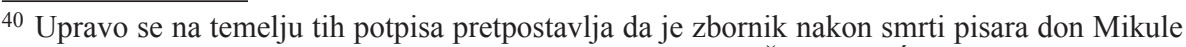
Fatevića neko vrijeme bio u Pakoštanima (usp. FRANOV-ŽIVKOVIĆ 2016: 9).
} 


\subsection{Zamjenjivanje frikativa $\check{z}$ u međusamoglasničkome položaju (rotacizam)}

Rotacizam, tj. zamjenjivanje frikativa $\check{z}$ sonantom $r$ u međusamoglasničkome položaju, razmjerno je česta pojava u Berčićevu i Fatevićevu zborniku. Najviše je potvrda rotaciranja čestice $\check{z} e$ kada je ona pridodana kakvoj zamjenici ili vezniku (142). Završno $e$ u rotaciranoj čestici že može i ispasti, kao u (143). U (144) izdvajamo nekoliko primjera iz Berčićeva zbornika u kojima je međusamoglasničko ž u čestici že očuvano:

(142) ûre (CBč 1v, 5r, 32r, 70r, 75r), tere (CBč 2v, 3r, 14v, 46r, 76v), ere (CBč 6v, 50v, 68r, 70r), nigdare (CBč 8v, 53r, 72v); ûre (CFat 1r, $7 \mathrm{v}, 19 \mathrm{v}, 56 \mathrm{r})$, nere (CFat 5v, 22v, 35r) nigdare (CFat 10r, 29r, 38v, $41 \mathrm{r}, 54 \mathrm{v}, 63 \mathrm{v})$, ere (CFat 14v, 15r, 25r, 33r, 74r), tere (CFat 14v, 20r, $24 \mathrm{v}, 52 \mathrm{r}$ ), ništare (CFat 40r, 64r), nigdore (CFat 23v)

(143) $\hat{u} r^{\prime}(\mathrm{CBč} \mathrm{57v),} \mathrm{ner'} \mathrm{(CBč} \mathrm{5v,} \mathrm{6r,} \mathrm{11r,} \mathrm{34r),} \mathrm{ništ(a)rb} \mathrm{(CBč} \mathrm{5v),}$ ništarb (CBč 52v), nigdar' (CBč 8v, 28r, 67r, 67v), nig'dir' (CBč 16r), nigdorb (CBč 70v); nigdar (CFat 19r, 20r, 32r, 54v, 60v, 70r, 73v), gdogoder (CFat 16v), ništar (CFat 17r, 66v), ter (CFat 76v)

(144) eže (CBč 20r), neže (CBč 54r), ničesože (CBč 12v, 72r).

Osim u čestici že, rotacizam je uobičajen u oblicima glagola moĉi (145) i gnati (146) i njihovim izvedenicama: ${ }^{41}$

(145) moreš’ (CBč 6v, 27r, 27v, 45v, 59v, 61r), morešb (CBč 51r), moreš (CBč 48v, 59r), more (CBč 4r, 8v, 48r, 50v, 68v, 75r), moremo (CBč 6r, 8r, 15v, 76r), morete (CBč 35r), vz'more (CBč 71r); moreš (CFat $2 \mathrm{v}, 6 \mathrm{v}, 12 \mathrm{r}, 32 \mathrm{v}, 35 \mathrm{r}, 73 \mathrm{v})$, more (CFat $4 \mathrm{r}, 7 \mathrm{v}, 14 \mathrm{v}, 34 \mathrm{v}, 62 \mathrm{v}, 64 \mathrm{r}$, 72r), moremo (CFat 5r, 24r, 57v, 67r), morete (CFat 2r, 24r)

(146) sarenu (CBč 38r), iz'reneši (CBč 42r), otrene (CBč 67v); izrene (CFat 9r).

$\overline{{ }^{41} \text { Kod glagola moĉi }}$ u Berčićevu zborniku zabilježena su četiri, a u Fatevićevu svega dva oblika s nerotaciranom osnovom: ne možahu š' nimb iti (CBč 24v), ni suseda svoego poz'nati možets (CBč 30v), može li enohb nasititi čestb d(u) šb (CBč 42v), ako s' počti biti možet' ukloni se ot nihb (CBč 54r); celahu ga i ne možaše ga ni edan isceliti (CFat 23r); spasal je mnozih a sebe ne može spasti (CFat 73v). Nekoliko je potvrda čuvanja međusamoglasničkoga ž zabilježeno i u oblicima izvedenih glagola prêmoĉi i vzzmoĉi: ne premožeš' nigdar ' $b(o g) b$ (CBč 28r), Aĉe vz'može r'ci mu poiti k'b(is)k(u)pu (CBč 48r); ali hoĉe imiti .ž. (=7) let glad ali $\cdot \tilde{e} \cdot(=6)$ miseci rat i da bude primožen od svoih nepriatel ali $\cdot \tilde{v} \cdot(=3)$ dni smart (CFat 31r); od dêvla premoženi na smarti (CFat 58r). 


\subsection{Tendencija dokidanja načela slogovne harmonije i druga palatalizacija}

U hrvatskome crkvenoslavenskom jeziku i srednjovjekovnim čakavskim govorima uvelike je narušeno praslavensko stanje kada je u pitanju provođenje druge palatalizacije velara (usp. MIHALJEVIĆ 1991: 108; HCSL 2014: 82). Naime, praslavenska tendencija ostvarivanja slogovne harmonije, koja je djelovala $» u$ nizovima gdje se u neposrednom susjedstvu nađu stražnji suglasnik i prednji samoglasnik« (MIHALJEVIĆ 2002: 147), zbog raznih je naknadnih glasovnih promjena i analogija prestala djelovati (usp. MIHALJEVIĆ 1991: 108) pa su se na mnogim mjestima u morfološkim paradigmama velari ponovno našli ispred prednjih samoglasnika. Ta činjenica brojne potvrde ima i u Berčićevu i Fatevićevu zborniku. Dosljednim prijelazom jeryja (y) u $i$ te stezanjem skupine yi $i$ velari su se našli pred samoglasnikom $i$ u genitivu jednine $a$-osnova ${ }^{42}$ (147), u akuzativu množine $a$-osnova i $o$-osnova ${ }^{43}$ (148), u nominativu jednine muškoga roda pridjeva (149) i u instrumentalu množine pridjeva svih triju rodova ${ }^{44}(150)$ :

(147) ruki (CFat 28v), muki (CFat 27r)

(148) $d(u) h i(\mathrm{CBč} \mathrm{2v),} \mathrm{grihi} \mathrm{(CBč} \mathrm{50r,} \mathrm{54v),} \mathrm{dl'gi} \mathrm{(CBč} \mathrm{5v),} \mathrm{bogi} \mathrm{(CBč}$ 10r); grihi $(\mathrm{CFat} 27 \mathrm{v}, 29 \mathrm{v})$, riki (CFat $27 \mathrm{v})$, slugi $(\mathrm{CFat} 72 \mathrm{v})$

(149) iûdêis'ki (CBč 2r), slat'ki (CBč 26r), dragi (CBč 27r); veliki (CFat 23r), človičaski (CFat 28v), izdraelski (CFat 28v)

(150) us'kimi (CBč 41v), velikimi (CBč 41v), d'ragimi (CBč 43r), slat'kimi (CBč 55r), slatkimi (CFat 1r), človičaskimi (CFat 12r), prevelikimi (CFat $55 \mathrm{v})$.

${ }^{42} \mathrm{U}$ obama su zbornicima potvrđeni i genitivni oblici $a$-osnova s nastavkom -e, očekivano bez provođenja druge palatalizacije: muke (CBč 27r); muke (CFat 16r, 19r, 21v, 29r, 55r, 66v), rike (CFat 12v). Takvih analoških preuzimanja nastavka ima i u drugim hrvatskoglagoljskim tekstovima (usp. HCSL 2014: 83).

43 Razmjerno se često u $a$-osnovama i $o$-osnovama u akuzativu množine ostvaruje i nastavak -e $(<-e)$, i to u prvima ( $a$-osnovama) kao posljedica priklanjanja tvrde promjene mekoj, a u drugima (o-osnovama) kao posljedica preuzimanja nastavka akuzativa množine meke promjene: grêš'nike (CBč 21r), grihe (CBč 44v, 56r, 64r), never 'nike (CBč 56v), muke (CBč 10r, 15r, 38r, 41r), ruke (CBč 26r, 40r), noge (CBč 26r); grišnike (CFat 16r), noge (CFat 27v, 29v, 72r, 75v), muke (CFat 41r, 50v, 54v), rike (CFat 42v). Kako se može vidjeti, druga se palatalizacija u oblicima akuzativa množine $a$-osnova i $o$-osnova s nastavkom -e (očekivano) ne provodi. Drugačije je u akuzativu množine $a$-osnova i $o$-osnova na $i$, gdje je provođenje druge palatalizacije potvrđeno (158), premda se s obzirom na podrijetlo nastavačnoga $i(<y)$ takvo što ne bi očekivalo.

${ }^{44} \mathrm{U}$ obama su zbornicima, kao i u drugim hrvatskoglagoljskim tekstovima, potvrđeni i oblici s provedenom drugom palatalizacijom koji ukazuju na utjecaj meke promjene (usp. HCSL 2014: 147): mnozimi (CBč 3v), druzimi (CBč 54r); mnozimi (CFat 70v). 
Osim glasovnim promjenama, načelo slogovne harmonije, kako je istaknuto, narušeno je i različitim analogijama. U Berčićevu i Fatevićevu zborniku ta se činjenica jasno očituje u oblicima nominativa (i vokativa) množine muškoga roda pridjeva i zamjenica. Kod pridjeva s osnovom na velarni suglasnik $\mathrm{u}$ navedenim se oblicima $-\mathrm{s}$ obzirom na to da je nastavak $i$ u nominativu (i vokativu) množine muškoga roda pridjeva i zamjenica diftonškoga podrijetla (usp. MIHALJEVIĆ 2002: 154; MIHALJEVIĆ, M. 2014: 62) - očekuje provođenje druge palatalizacije koje je doista i potvrđeno u nizu primjera (151). Ipak, kao posljedica analoškoga ujednačavanja nominativa množine prema ostalim oblicima u pridjevskoj paradigmi, u obama su zbornicima potvrđeni i oblici bez provedene druge palatalizacije. Više je takvih primjera zabilježeno u Fatevićevu zborniku (152), a posvjedočeni su i u drugim hrvatskoglagoljskim tekstovima, uključujući i one liturgijskoga karaktera (usp. MIHALJEVIĆ 1991: 109-110; MIHALJEVIĆ 2015: 542; HCSL 2014: 83):

(151) nici (CBč 1r, 1v, 66v), taci (CBč 4v, 17v, 18r), anj(e)lsci (CBč 30r), rim 'sci (CBč 47v), velici (CBč 58r), mrs'ci (CBč 58r), krot'ci (CBč 61r, 67v), ubozi (CBč 18r, 74v), nazi (CBč 17v, 74v), druzi (CBč 1r, 65r), mnozi (CBč 1r, 14r, 43v, 67v, 71r), nebozi (CBč 36v, 63r); glusi (CFat 60v), drazi (CFat 14r), nebozi (CFat 15r), mnozi (CFat $17 \mathrm{v}, 21 \mathrm{v}, 23 \mathrm{r}, 24 \mathrm{v}, 46 \mathrm{r}, 71 \mathrm{v})$, druzi (CFat 23r, 46v, 63r, 65v), drazi (CFat 23r), suhi (CFat 16r), nici (CFat 27v, 53v), velici (CFat 39v), pridrazi $(\mathrm{CFat} 64 \mathrm{v})$

(152) niki (CBč 1r, 23v, 36v), korabal'ski (CBč 11r), gluhi (CBč 13r), blagi (CBč 14r), visoki (CBč 16r); niki (CFat 30r, 45v, 46v), drugi (CFat 9r, 33v, 53r, 62v, 63r, 67r), mnogi (CFat 15r, 45r), židovski (CFat 15r), poganski (CFat 15r), niki (CFat 15v), veliki (CFat 16v), erusolimski (CFat 24v), dragi (CFat 60v).

Druga se palatalizacija očekivano provodi u nominativu množine $o$-osnova muškoga roda (153), u dativu i lokativu jednine $a$-osnova (154), u lokativu jednine $o$-osnova muškoga roda (155), u lokativu množine $o$-osnova muškoga roda (156), u akuzativu dvojine $a$-osnova (157) ${ }^{45}$ itd.:

${ }^{45}$ U CBč i CFat dvojina se ne čuva sustavno (s tim da je, u cjelini gledano, osjetno bolje sačuvana u CBč nego u CFat) pa bi se oblici navedeni u (156) mogli tumačiti i kao množinski, $\mathrm{s}$ neočekivanim provođenjem druge palatalizacije ispred $-i(<-y)$, koje je inače potvrđeno $u$ obama zbornicima (158). Uz pretpostavku da se u (157) ipak radi o dvojinskim oblicima, nastavak - $i$ može se tumačiti kao ikavski refleks jata ili kao posljedica utjecaja meke promjene na tvrdu. Vrijedi također napomenuti da se u obama zbornicima iznimno pronalaze i akuzativni oblici bez provedene druge palatalizacije: ruki (CBč 40v); ruki (CFat 71v). 
(153) grêšnici (CBč 56r), nevernici (CBč 56v), êzici (CBč 66r); zlotvorci (CFat 2v), ožurnici (CFat 2v), proroci (CFat 15r), grišnici (CFat $72 \mathrm{v})$

(154) mисі (CBč 64v), ruci (CBč 70v); rici (CFat 12r), muсi (CFat 72r)

(155) grêsi (CBč 5r), grisi (CBč 60r), êzici (CBč 68v), strasi (CBč 76r); človici (CFat 3v);

(156) $\operatorname{pr}(a) v(a) d$ 'nicih' (CBč 5v), oblacehb (CBč 6r), č(lovê) cêhb (CBč 7r); pro(ro) cih (CFat 5v), oblacih (CFat 9r, 14v)

(157) nozi (CBč 3r, 30r, 63r), ruci (CBč 30r, 53r); nozi (CFat 30r, 71v), ruci (CFat 76r).

Rijetki su u navedenim kategorijama primjeri u kojima druga palatalizacija nije provedena. Oni su, primjerice, potvrđeni u lokativu jednine $a$-osnova (raki CBč 11v, ruki CBč 15r; zipki CFat 27r, muki CFat 79v) te bi se mogli pripisati utjecaju živoga (čakavskoga) govora (usp. HCSL 2014: 111). U obama zbornicima, a osobito u Fatevićevu, ima i suprotnih primjera, tj. primjera provođenja druge palatalizacije ondje gdje se ona ne bi očekivala, primjerice $u$ akuzativu množine $a$-osnova i $o$-osnova (158) ili u instrumentalu množine $o$-osnova (159). Takvi su primjeri potvrđeni i u hrvatskoglagoljskim misalima i brevijarima, osobito u instrumentalu množine (usp. HCSL 2014: 111), te pokazuju da se druga palatalizacija nesustavno provodila i nakon prijelaza $y>i$.

(158) pravadnici (CFat 16r), grišnici (CFat 14r, 16v, 18v), grisi (CFat 45v, 49r, 51v, 55v, 63r, 65v, 77v), vuci (CFat 77v), pruzi (CFat 77v)

(159) grêsi (CBč 73r), vrazi (CBč 1r), rozi (CBč 14r); svitilnici (CFat 7v), naslednici (CFat 31r), proroci (CFat 35r).

\subsection{Suglasničke skupine}

\subsubsection{Odrazi suglasničkih skupina sa sonantom j}

U obama su zbornicima, dakako, vidljivi rezultati prve, tj. praslavenske jotacije (160). Kod labijalnih se suglasnika $b, p, m$ i $v$ između njih i glasa $j$ umeće $l$ koje se zatim jotira u $l$ (161):

(160) plakati (CBč 24r) plače (CBč 26r), pokaza (CBč 27r) pokažutb (CBč 15r), moliti (CBč 7r) molû (CBč 43v), nasititi (CBč 42v) nasiĉu (CBč 23r); plakati (CFat 12r) plač (CFat 9v), duh (CFat $10 \mathrm{v}) \sim d u s ̌ a(\mathrm{CFat} 4 \mathrm{r})$, pisati (CFat 7v) piše (CFat 16r), prikazati (CFat 43r) prkaže (CFat 64v) 
(161) zlûbleniki (CBč 19v), pogublû (CBč 63r); otkuplen'e (CBč 66r), prestuplenie (CBč 69v); priemleši (CBč 6r), glum'leniê (CBč 68v); poz'dravlenie (CBč 67r), pravlû (CBč 73r); lûblenik (CFat $37 \mathrm{r})$, giblet $(\mathrm{CFat} 19 \mathrm{v})$, posiplu (CFat 11v), pristuplena (CFat 14r), oslipleni (CFat 16v), ulomlenu (CFat 12v), vazimle (CFat 78v), pravlû (CFat $35 \mathrm{r})$, blagoslovlena $(\mathrm{CFat} 1 \mathrm{v})$, ponovleni $(\mathrm{CFat} 2 \mathrm{r})$, êvlenii (CFat 2v).

Odrazi su praslavenskih skupina $* j$ i $* d j$ u obama zbornicima očekivani. $\mathrm{Na}$ mjestu skupine * $t j$ redovito se ostvaruje slovo $\mathrm{u}$, kao u (162), koje u tome položaju, kako je već istaknuto, nedvojbeno treba čitati kao [ć]. Skupina *dj u Fatevićevu zborniku ima isključivo čakavski odraz $j$, kao u (163). Taj odraz uvjerljivo prevladava i u Berčićevu zborniku, kako se vidi u (164), no u njemu je zabilježeno i nekoliko primjera sa starocrkvenoslavenskim odrazom $\check{z} d$ (165):

(162) noseĉi (CBč 19v), sideĉi (CBč 28r), noĉi (CBč 40r), igraûcee (CBč 45r); noĉi (CFat 6r), hoteĉi (CFat 14v), prikazuûci (CFat 22r), govorecii (CFat 22r), svemoguĉega (CFat 28r)

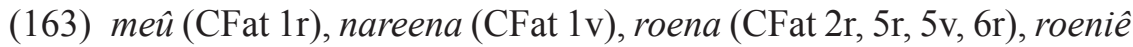
(CFat 2r), prihaê (CFat 2r), roistvo (CFat 5r, 5v) prohoêse (CFat 10r), saziût (CFat 11r), ograeno (CFat 13v), naslaûu (CFat 16v), viêse (CFat 19v), pohaêla (CFat 20r), viû (CFat 20r), osloboen (CFat 21r), sprovoêhu (CFat 24r), gospoe (CFat 24r), čuêhu (CFat $24 \mathrm{v})$, roen (CFat 27r), tuih (CFat 28v), suen (CFat 49v), dohoêše (CFat 50v)

(164) hoêše (CBč 15r, 60r), hoêhomo (CBč 74r), roen' (CBč 10v, 46v, $47 \mathrm{v}$ ), poroen'e (CBč 26r), suû (CBč 43r, 56r), osuenb (CBč 47r, 65r), mêे (CBč 62r, 66v, 76r), gospoe (CBč 66v, 76r), saziû (CBč $55 \mathrm{v})$, tuega (CBč 7r, 68r), žêu (CBč 53v)

(165) graždane (CBč 24v), ugaždâ̂̂e (CBč 73v), osuždaûĉe (CBč 74v), osuždaûcih' (CBč 75v).

Odraz praslavenske suglasničke skupine *stj u hrvatskome se crkvenoslavenskom stopio s odrazom skupine *skj. U većini hrvatskoglagoljskih tekstova na mjestu tih skupina dolazi slovo $\mathbf{w}, \mathrm{s}$ tim da nije dokraja jasno ima li

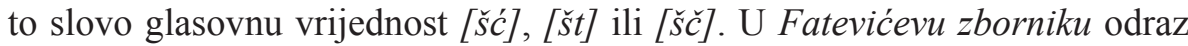
skupina $*_{s t j}$ i $*_{s k j}$ nedvojbeno treba čitati kao [šć] s obzirom na to da na njihovu mjestu, kako smo vidjeli, redovito dolazi dvoslov шu (166). U Berčićevu zborniku slovo w može se čitati na dva načina, kao [ć] i kao [ک̌ć]. Na čitanje $[c ́ c$ upućuju morfonološke smjene $[t] \sim[c ́]$ u primjerima tipa vratiše 
(CBč 22v) vraĉahote (CBč 20v) te sporadični primjeri bilježenja izgovora [ک̌́c slovnom skupinom ш'ü navedeni u (20) koje radi preglednosti ponavljamo u (167). Ipak, smjene [st] [̌́ć] u primjerima tipa otpustitb $(\mathrm{CBč} 7 \mathrm{v}) \sim$ otpuĉenie (CBč 6r) te primjeri navedeni u (167) jasno pokazuju da na mjestu praslavenskih skupina *stj i *skj u Berčićevu zborniku treba također pretpostaviti izgovor [ک̌́ć] (168):

(166) odpušĉenie (CFat 1r), blagovišçena (CFat 20r), dopušçâuci (CFat 40r), pokršĉeni (CFat 2r), pristanišce (CFat 2v), išce (CFat 3r), išcuciom (CFat 19v), godišce (CFat 55v), mešçane (CFat 20v), navišcene (CFat 35v), pribižišce (CFat $17 \mathrm{v}$ ), šĉap (CFat 10v), šcapom (CFat 6v, 53r), otpušĉenie (CFat 32r), skrovišĉa (CFat 13v, $30 \mathrm{v}$ ), pribižišce (CFat 17v), kršĉen (CFat 20r), zapušĉena (CFat 15r), zaščiti (CFat 20v)

(167) očišçevaše (CBč 36r) ( očiĉena CBč 47r), smet'lišĉ́i (CBč 70r), sudiš $\hat{c} e$ (CBč 70r) ( besedeliĉe CBč 70r), tašçaê (CBč 70v) ( taĉih' CBč 68v), laš 'çaše (CBč 70v) ( laĉaše CBč 10r)

(168) ĉap (CBč 12v), poĉă̌e (CBč 21v), îce (CBč 23r), očiĉenb (CBč $31 \mathrm{v})$, sudiĉe (CBč 72r), besedelice (CBč 75r).

Na mjestu praslavenske skupine *rj redovito se u Berčićevu i Fatevićevu zborniku ostvaruje $r$ (169):

(169) t'voru (CBč 44r), razoru (CBč 55v), boru (CBč 63v); govoru (CFat $12 \mathrm{r}, 32 \mathrm{v}, 36 \mathrm{r})$, more (CFat 16r, 27v).

U Fatevićevu zborniku, očito pod utjecajem narodnoga (čakavskoga) jezika, vrlo su često potvrđeni primjeri provođenja nove (sekundarne) jotacije (170). U Berčićevu zborniku analognih primjera nema, što je očekivano s obzirom na činjenicu da se nova (sekundarna) jotacija »odvijala (...) tijekom 16. i 17. stoljeća« (MATASOVIĆ 2008: 162):

(170) braĉa (CFat 2r, 15r, 27r, 72v), cviĉa (CFat 3r), cvicem (CFat 7v, $29 \mathrm{v}, 75 \mathrm{v})$, cviĉe (CFat $27 \mathrm{v})$, pristanuĉe (CFat 4r, 59v), spomenuĉe (CFat 15v), uskrsnuce (CFat 47r, 47v), vesele [vesele] (CFat 4v, 5r), rasuene [rasujeńe] (CFat 15v), poniženem [ponižeńem] (CFat 16v), marmorane [marmorańe] (CFat 46v), strplene [strpleńe] (CFat $72 \mathrm{r})$.

Osobito je zanimljivo promotriti odraze sekundarne skupine $s t j(<s t \partial j)$. U pismu se odraz toga slijeda u većini primjera bilježi slovnom skupinom $s \hat{c}$ (ه'̈) (171), no u trima primjerima navedenima u (172) odraz je zabilježen 
skupinom šć (யய'). Upravo bi ta tri primjera mogla ukazivati na to da zapis $s \hat{c}$ u primjerima (171) predstavlja samo grafijski, a ne i fonološki ostvaraj. Drugim riječima, na temelju primjera (172) moglo bi se utvrditi da je fonološki rezultat sekundarne jotacije skupine stj $(<s t a j)$ u Fatevićevu zborniku šć:

(171) časĉu (CFat 15v, 76r), jakosĉu (CFat 62v), lakomosĉu (CFat 28r), lisĉe (CFat 16r), milosĉu (CFat 60r), napasĉu (CFat 65r), srditosĉu (CFat 28v), svitlosĉu (CFat 76v), zavidosĉu (CFat 28v), bolesĉu (CFat 61v)

(172) svetošĉu (CFat 19r), svetošĉom (CFat 19v), linošĉu (CFat 28v).

Da je u vremenu nastanka Fatevićeva zbornika na zadarskim otocima nova jotacija uglavnom već bila provedena, pokazuju primjeri iz matičnih knjiga. Primjerice, u glagoljskoj matičnoj knjizi vjenčanih Župe Uznesenja BDM na Ravi 1613.-1635., dakle po prilici iz vremena kada je nastao Fatevićev zbornik, uvjerljivo prevladavaju primjeri u kojima je nova jotacija provedena: navišcena [navišćeńa] (GKM Rava 2016: 222), zapričene [zapričeńe] (GKM Rava 2016), vinčane [vinčańe] (GMK Rava 2016: 223).

\subsubsection{Odrazi suglasničke skupine vbs}

Početna se suglasnička skupina vbs- u Berčićevu zborniku, kao i u drugim hrvatskim crkvenoslavenskima tekstovima, redovito čuva (173):

(173) v'se (CBč 4r), vs(a)kom' (CBč 13v), vsi (CBč 17r), vsimi (CBč $17 \mathrm{v})$, vsimb (CBč 18v), vs(e)m(o)guci (CBč 46r), vsakb (CBč 48r), vs(a)gda (CBč 49r), vsag'da (CBč 67v), vsakoi (CBč 49r), vsakoga (CBč 54r, 56r), vs(e)mogi (CBč 66v), v'simi (CBč 68r), v'sag'da (CBč 69v), v’su (CBč 70r).

U Fatevićevu zborniku stanje je pak drugačije pa je ta skupina u većini slučajeva pod utjecajem stanja u narodnome jeziku premetnuta (174), a tek se u manjem dijelu primjera čuva starije, nepremetnuto stanje (175):

(174) svih (CFat 2r), svim (CFat 2r), sve (CFat 3r, 3v), svu (CFat 3v), svako (CFat 5r, 11v), svemu (CFat 5r), svaki (CFat 7r), svega (CFat $7 \mathrm{v})$, svaka (CFat $14 \mathrm{v}, 35 \mathrm{r}$ ), svakoi (CFat 38v), svemoguci (CFat $27 \mathrm{v}$ ), svemogucim (CFat 66v)

(175) vsem (CFat 22v), vse (CFat 30v, 56r, 66r, 71v), vsi (CFat 38v, 66r), vsu (CFat 32r), vsim (CFat 32r, 66r), vsih (CFat 48r, 49r), vsemu 
(CFat 60v), vsakomu (CFat 64v), vsemogucemu (CFat 67r), vsemogoga (CFat 76v).

\subsubsection{Suglasnička skupina čьr}

Stara se početna skupina čbr u Berčićevu i Fatevićevu zborniku, kao i u drugim hrvatskoglagoljskim liturgijskim i neliturgijskim tekstovima (usp. DAMJANOVIĆ 2008: 71; DAMJANOVIĆ 2009: 373; MIHALJEVIĆ, A. 2014; LOZIĆ KNEZOVIĆ 2016), beziznimno čuva (176):

(176) čr'tu (CBč 2r), čr'ni (CBč 17v, 18r), čr'nici (CBč 21v), čr'neiša (CBč 43v), črêve (CBč 19r), črêve (CBč 19r), črêva (CBč 19r, 22r), čr rêva (CBč 42r), črvb (CBč 62v), č'rvi (CBč 32r, 64v, 70r), č'rvom' (CBč 65r), čr'vi (CBč 20r); čreva (CFat 6r), črevi (CFat 8r, 9v, 19r, 29r), črvi (CFat 30v), črv (CFat 77r).

Takvo stanje ne čudi s obzirom na činjenicu da se ta skupina i danas uglavnom dobro čuva u čakavskim govorima na otocima pred Zadrom (usp. BENIĆ 2014: 33; ŠPRALJA 2016.a: 75-76; ŽUŽAK 2016: 41).

\subsubsection{Suglasnička skupina čbt}

U Berčićevu zborniku beziznimno se čuva i skupina čbt (177). Drugačija je situacija u Fatevićevu zborniku u kojem je ta skupina uglavnom zamijenjena mlađom skupinom št (179), a tek je u nekoliko primjera očuvana (178):

(177) čteniê (CBč 2v), čten'em'(CBč 11v), čtenie (CBč 72r), počten'emb (CBč 14r), počtuûcihih (CBč 16r), počtovaše (CBč 18r), počtene (CBč 26v), počtovali (CBč 58r), čtovaše (CBč 64r), čtešs (CBč $68 \mathrm{v})$, prepočtene (CBč $70 \mathrm{v})$, čtuĉe (CBč $75 \mathrm{v})$

(178) pročtiti (CFat 31r), pročtil (CFat 31r), čti (CFat 31v), počtovani (CFat 44r), pripočteni (CFat 49r)

(179) štûি (CFat 6v, 74r), šti (CFat 7v, 52v, 53r, 70r), poštovati (CFat 7v), poštenu (CFat 14v), poštuûci (CFat 18v), poštena (CFat 19r), poštuite (CFat 24v), štovati (CFat 24v), štiti (CFat 35v), poštovanomu (CFat 44r), štiti (CFat 58v), štil (CFat 60r).

\subsubsection{Jednačenje po zvučnosti}

Susjedni šumnici različiti po zvučnosti u obama se zbornicima uglavnom dosljedno jednače, i to tako da se prvi prilagođava drugomu, kako se vidi u (180): 
(180) slat'ka (CBč 13r), prêslat'ki (CBč 30v), teš'ko (CBč 41r, 65r), teš'kim' (CBč 65r); slatkimi (CFat 1r), slatkostiû (CFat 1r, 26v), slatko (CFat 5r, 26v, 27v), slatkimi (CFat 14v, 15v), zipki (CFat 27r), teško (CFat 7r, 78v), tešku (CFat 7r), teškoĉu (CFat 27r), teška (CFat 38v), priteške (CFat 60v, 65r).

Posebno treba razmotriti sljedove suglasnika različitih po zvučnosti koji se ostvaruju na granici prefiksa i korijena. U Fatevićevu zborniku u tim je slučajevima jednačenje po zvučnosti u pismu uglavnom redovito potvrđeno u prefiksima $v z-/ u z-, s-, i z-$ i raz- (181). Primjeri su etimološkoga pisanja u spomenutim prefiksima vrlo rijetki. U zborniku su pronađena samo dva takva primjera, a u obama se radilo o prefiksu raz- (182):

(181) uskrsnuti (CFat 45r, 48r), uskrsnuĉ (CFat 71r), vskrsnul (CFat 20r); zgodi (CFat 6r, 12v, 21r), zgor (CFat 44r, 66v), odzgora (CFat 48r), zdvignuti (CFat 16r), zdviže (CFat 28r), zdvižemo (CFat 75v); rasrdit (CFat 9r), rasrdiše (CFat 11r), rastočet (CFat 11r), rastočeniû (CFat 11r), raspeto (CFat 14r), rasčine (CFat 16r), raspadaše (CFat $22 \mathrm{v})$, raspali (CFat 26r), rastegnuše (CFat 73v); iscelim (CFat 7r), ispuni $(\mathrm{CFat} 9 \mathrm{v}, 12 \mathrm{r}, 29 \mathrm{r}, 29 \mathrm{v})$, ispuniti $(\mathrm{CFat} 16 \mathrm{v})$, isplaka (CFat $13 \mathrm{r})$, isplačut (CFat 14v), ispovidati (CFat 33v), ispovidâu (CFat 33r), ispovidnici (CFat 19r, 66r), isprositi (CFat 18r, 33v), ishodi (CFat 18v, 24v, 37r, 57v), ispita (CFat 21v), isceliti (CFat 23r), isprositi (CFat 27v), ispelati (CFat 28v), iskupil (CFat 30r)

(182) razčiniti (CFat 15r), raztu(ma)čeni (CFat 49v).

Etimološko je pisanje, međutim, u Fatevićevu zborniku sasvim uobičajeno kada se radi o prefiksima $p o d-, n a d-, o d$ - i $o b$ - (183). Tek je u jednome primjeru jednačenje po zvučnosti potvrđeno u pismu (184):

(183) podpisanu (CFat 65v); nadhodi (CFat 19v), nadhaêse (CFat 22r); odpušcenie (CFat 1r), odpusti (CFat 75r), odkupi (CFat 1r), odkriveni (CFat 10v), odkriveno (CFat 15r), odstupaše (CFat 22r), odkrivenih (CFat 52r), odstupa (CFat 63v), odkuplen (CFat 65v), odkupitela (CFat 70v); obhodno (CFat 5r), obsluževaše (CFat 5r), obsluževati (CFat 35r, 77v), obsede (CFat 71v), obseniti (CFat 76v)

(184) otpušĉenie (CFat 32r).

U Berčićevu je zborniku stanje po prilici slično pa se i u njemu jednačanje po zvučnosti redovito provodi na granici prefiksa $v z-, s-, i z$ - i raz- i korijena 
(185), no za razliku od stanja u Fatevićevu zborniku, jednačenje po zvučnosti u pismu je potvrđeno i na granici prefiksa od- i korijena koji započinje bezvučnim suglasnikom (186):

(185) vs 'krsnet' (CBč 2r), vskrsnuti (CBč 63v), vskrêšenie (CBč 72v), vspoûtb (CBč 45v), v'strêpetahb (CBč 32r), v'strubitb (CBč 17v), v'sklikšsei (CBč 55r), zbirati (CBč 45r), zbiraû (CBč 67v), z'berimo (CBč 39r), z'bor' (CBč 75r), z'bude (CBč 26r), ras 'tlêût' (CBč $39 \mathrm{v})$, rastavit' (CBč 56r), ras 'trza (CBč 24r), ras'sr'di (CBč 8r), ras'pade (CBč 3r), ras'teg'nuti (CBč 10r), rassikaûci (CBč 16v), is 'tleši (CBč 2r), ishoditb (CBč 33r), ispisati (CBč 66r), is 'pitati (CBč 14r), is'cêli (CBč 32r), is'pi (CBč 34r), iskušenie (CBč 6r), is 'pl'ni (CBč 36v), is'pov(ê)dati (CBč 42v)

(186) ot 'stup'niče (CBč 3v), otstupiste (CBč 19v), otsbtupi (CBč 65v), otsiče (CBč 45v), otsicii (CBč 45v), otkupiti (CBč 45v, 66r), otkupi (CBč 31v, 49v), otkuplen'e (CBč 66r), otpuĉajuce (CBč 5r), otpuĉamo (CBč 5v), otpuĉenie (CBč 6r, 32r, 46v), otpus 'tiš' (CBč $7 \mathrm{v})$, otpustitb (CBč 7v), otpravišse (CBč 11r).

Jednačenje u pismu ipak nije potvrđeno u rijetkim primjerima s prefiksima ob- i pod- (187), a rijetko može izostati i u drugim prefiksima, kod kojih se, kako smo vidjeli, uglavnom provodi (188):

(187) ob stupiti (CBč 53r), ob'celivaše (CBč 70v), pod'pali (CBč 10r)

(188) v'z'pijut'(CBč 16v), v'z'piše (CBč 63r), iz'čitaše (CBč 12r), sbiraût (CBč 44r), s'birâu (CBč 68r, 68v), s'beremo (CBč 72r).

Na granici korijena i sufiksa jednačenje po zvučnosti u pismu može izostati u obama zbornicima, osobito ako se radi o sufiksu -stv- (189):

(189) gospodstvuet' (CBč 77v); podobstvo (CFat 7v), sobstva (CFat 34v), zibci (CFat 27r), bogolubci (CFat 29r), gospodstvo (CFat 28r, 29r), ludstva (CFat 74v), množstvo (CFat 72v).

I u Berčićevu i u Fatevićevu zborniku jednačenje po zvučnosti u pismu je nerijetko potvrđeno i na granici riječi (190). Takvi su primjeri razmjerno česti i u drugim hrvatskoglagoljskim tekstovima (usp. DAMJANOVIĆ 2008: 76; MIHALJEVIĆ 2015: 544).

(190) is' tela (CBč 13v), is' korabla (CBč 22r), is' črêva (CBč 22r), is' tam'nice (CBč $34 \mathrm{v}, 38 \mathrm{v})$, is ' propas 'ti (CBč 41r), is' crkve (CBč 44v), nis' kapetolê (CBč 22r), bes' čis 'la (CBč 17r), pres' čisla 
(CBč 71v); is čreva (CFat 6r), is tebe (CFat 26v), is tila (CFat 61v), is koga (CFat 62r), is potoka (CFat 73r), z dvima divoikama (CFat $19 \mathrm{v}), z$ dušom (CFat 21v), z dêvlom (CFat 41r), z drugim (CFat 47r), $z$ duhom (CFat 67r).

\subsubsection{Jednačenje po mjestu tvorbe}

U Berčićevu je i Fatevićevu zborniku u pismu potvrđeno i jednačenje suglasnika po mjestu tvorbe. To je jednačenje ograničeno na dentale $s$ i $z$, koji pred palatalima u pismu obično prelaze u svoje palatalne parnjake $\check{s}$ i $\check{z}(191)$ :

(191) višnega (CBč 13r), viš’nemu (CBč 14v, 63v), viš’nago (CBč 14r), viš'ni (CBč 13r, 13v, 72v), današ'nago (CBč 4v), današni (CBč 77v), proš’na (CBč 7v), niž’nihb (CBč 13v), nižni (CBč 72v), bliž’nega (CBč 53r); današne (CFat 16r), današni (CFat $5 \mathrm{r}, 18 \mathrm{v}, 19 \mathrm{r}, 27 \mathrm{v}, 30 \mathrm{r})$, mišleniê (CFat 3v, 48r, 58r), pomišleni (CFat 29v), smišlati (CFat 42r), razmišlenie (CFat 70v), višnemu (CFat 9r, 31r), višni (CFat 10v, 12v), višnago (CFat 76v), prošne (CFat 9v), svetošĉu (CFat 19r), svetoščom (CFat 19v), bližni (CFat 49v, 50r).

Kao i kod jednačenja po zvučnosti, i ovdje su morfonološki i glasovni prikaz u sukobu (usp. HCSL 2014: 88) pa nije neobično što nerijetko nalazimo i primjere u kojima jednačenje po mjestu tvorbe u pismu nije potvrđeno. U Fatevićevu zborniku jednačenje u pismu najčešće izostaje u skupini sĉ (192), koja se, kako je istaknuto u odjeljku 4.14.1., u pravilu bilježi na mjestu sekundarne skupine $s t j(<s t a j)$. Da je u primjerima navedenima u (192) sĉ doista samo grafijski, a ne i fonološki ostvaraj, pokazuje već spomenuto sporadično bilježenje slovne skupine $\check{s} \hat{c}$ (Шய̈) - svetošĉu (CFat 19r), svetošçom (CFat $19 \mathrm{v})$, linošĉu (CFat 28v) - na mjestu stj (<staj).

(192) časçahu (CFat 4v), časĉu (CFat 15v), došasĉe (CFat 46v), krsĉanina (CFat 33v), krscianstvo (CFat 23v), lakomosĉu (CFat 28r), lisĉe (CFat 16r), liscem (CFat 58v), milosĉu (CFat 60r), napasĉu (CFat 65r), srditosĉu (CFat 28v), svitlosĉu (CFat 76v), trsĉu (CFat 73r), zavidosĉu (CFat 28v), bolesĉu (CFat 61v).

Drugdje se jednačenje uglavnom dosljedno provodi i u pismu. Iznimka je u Fatevićevu zborniku tek oblik rasčine (CFat 16r) u kojem je u pismu zabilježeno jednačenje po zvučnosti, ali ne i jednačenje po mjestu tvorbe, odnosno u Berčićevu zborniku oblik iz'čitaše (CBč 12r) u kojem u pismu nije provede- 
no ni jednačenje po zvučnosti ni jednačenje po mjestu tvorbe. Jednačenje po mjestu tvorbe u pismu izostaje i u primjerima hinbu (CFat 63v), hinbam (CFat 66v), hinbeno (CFat 78v).

Kao jednačenje po zvučnosti, i jednačenje po mjestu tvorbe provodi se na granici riječi. Jednačenje je pritom dosljedno provedeno u svezama prijedloga $s$ i različitih padežnih oblika ličnih i posvojnih zamjenica za treće lice (193):

(193) š nimb (CBč 8v, 17v), š’nimb (CBč 24v, 36v, 64r, 70r), š nimi (CBč 17v), š’ nima (CBč 37r), š nêे (CBč 52r); š nêे (CFat 9v), š nimi (CFat 18v), š nim (CFat 21r, 24r, 61v, 73v), š nih (CFat 38r), š negovimi (CFat 45r), š negovom (CFat 60r).

Drugačije je u svezama prijedloga $i z$ i zamjeničkih oblika. U Fatevićevu zborniku takve su sveze potvrđene tri puta pri čemu je jednačenje po mjestu tvorbe u pismu jednom potvrđeno (iž nee CFat 26v), dok je dvaput izostalo (iz nih CFat 47r, 52r). U Berčićevu zborniku dvaput su potvrđene sveze prijedloga $i z$ i zamjeničkih oblika i ni jednom jednačenje po mjestu tvorbe nije potvrđeno u pismu (iz' nee CBč $52 \mathrm{v}$, iz' nêi CBč 52v). Primjeri jednačenja po mjestu tvorbe na granici prijedloga i zamjeničkih oblika (nesustavno) su potvrđeni i u drugim neliturgijskim zbornicima (194) (usp. KOSIĆ 2010: 32; MIHALJEVIĆ, A. 2014: 228):

(194) š’ nimi (CIvan 25r), ž’ nihb (CIvan 34v), š nevb (CIvan 92r); iž negože (CŽg 112r), š’ nêे (CŽg 112r); iž nihb (CPetr 60v), š nimi (CPetr 78v), prêž nega (CPetr 152v); b'rež' negova (RitKlim 34r), š'nim' (RitKlim 143r).

\subsubsection{Ostale promjene u suglasničkim skupinama}

U Fatevićevu zborniku nisu potvrđeni primjeri koji bi sadržavali suglasničku skupinu $z d b n$, dok se u Berčićevu zborniku ta skupina u dijelu primjera čuva (prazd'ne CBč 54r, praz'dno CBč 67v, pr(a)zdn(i)ka CBč 76r), a u dijelu je primjera pojednostavnjena ispadanjem dentala $d$ (praz'novaše CBč $24 \mathrm{v}$, praz'nihb CBč 54r). Inače je u starocrkvenoslavenskim tekstovima skupina $z d b n$ uvijek pojednostavnjena u oblicima glagola prazdniti i njegovih izvedenica $(z d b n>z n)$, dok se u drugim riječima istoga tvorbenog gnijezda ponegdje čuva, a ponegdje pojednostavnjuje (usp. GADŽIJEVA 2009: 140). U hrvatskim je crkvenoslavenskim tekstovima skupina $z d b n$ uglavnom dobro očuvana premda, dakako, ima i izuzetaka (usp. GADŽIJEVA 2009: 140-141). 
Skupina stbn bilježi se razmjerno često i u jednome i u drugome zborniku (195), no u obama su potvrđeni primjeri u kojima je ispao dental $t$ (196):

(195) prečas tnomu (CBč 13r), častno (CBč 19v), žalostnihb (CBč 19v); pričestnica (CBč 64v), častno (CFat 5r), žalostni (CFat 6r), žalostnie (CFat 27r), koristna (CFat 65v)

(196) žalos'ni (CBč 14r), žalos'nihb (CBč 20r); časnosti (CFat 1r), žalosna (CFat 27r).

$\mathrm{U}$ Fatevićevu zborniku razmjerno su česti primjeri epenteze dentala $d \mathrm{u}$ istomorfemske suglasničke skupine $z r$ i $z r r$ (197). Zabilježen je ipak primjer požriti (CFat 63r), dakle bez epenteze sekundarnoga $d$.

(197) izdravilskih (CFat 21r), izdraelski (CFat 28v, 67v), izdravili (CFat 33r), izdravilelva (CFat 33r), izdravila (CFat 33r), izdravil (CFat 33r), ždribi (CFat 24r, 71v).

Osim u istomorfemsku suglasničku skupinu $z r$, neetimološko $d$ može biti umetnuto i u skupinu $z r$ nastalu na granici dvaju morfema (198):

(198) razdrušeniê (CFat 1r), razdruši (CFat 15r, 60r), razdrušen (CFat 15r), razdrušiti (CFat 46v).

U Berčićevu je zborniku stanje poprilično drugačije nego u Fatevićevu. Zabilježen je, naime, samo jedan primjer epenteze neetimološkoga $d$ u skupinu $z r$, i to na granici dvaju morfema (razdrušeniem' CBč 51v). U istomorfemskim skupinama $z r$ i žr epenteza nije potvrđena (199):

(199) pož'riti (CBč 3r), pož'reš' (CBč 53v), pož'ri (CBč 3r), ž'rêb' (CBč 34r), žrêb' (CBč 34r), ž'rib' (CBč 39r), ž'ribomb (CBč 39r), žrêbac' (CBč 59v), ž'rêbac' (CBč 54v).

Umetanje neetimološkoga $d$ u skupinu $z r$ zabilježeno je i u drugim hrvatskoglagoljskim tekstovima: izdravilevih (CPetr 87r), proždrljivac (CGrš 131v, CPet 33r; prema REINHART 2012: 219), izdravil ski (KKor, prema RADOŠEVIĆ 2012: $182^{\mathrm{F}}$ ) itd. $^{46}$

Dental $l \mathrm{u}$ obama zbornicima može prijeći u palatal $l$ iza velara $k$. S obzirom na to da se fonem $/ /$ / bilježi slovom 由l, jednako kao i fonem $/ l /$, o tome se prijelazu zaključuje na temelju činjenice da se u primjerima navednima u (101) prednji nosni samoglasnik odrazio kao $a$, što je moguće objasniti samo

46 Više o datiranju, arealnom prostiranju i relativnoj kronologiju epenteze dentalnih okluziva $t$ i $d$ u skupine $s r, z r$ i $̌ r r$ v. u KRMPOTIĆ 2015. 
uz pretpostavku da slovo 他 koje se ostvaruje pred njim ima glasovnu vrijednost [l]. Osim iza $k$, prijelaz $l>l, ~ \mathrm{u}$ čakavskim je govorima zadarskoga područja potvrđen i iza velara $g$ i $h$ (usp. primjere glëdati, $h l ̧ \imath$ i iz Kukljice; prema BENIĆ 2014: 34-35). U istoj se okolini stoga taj prijelaz može pretpostaviti i u Berčićevu i Fatevićevu zborniku, no zbog spomenute dvojake glasovne vrijednosti slova 他 tu pretpostavku nije moguće dokazati.

U slijedu okluziva i afrikate $k c ́$ okluziv se u obama zbornicima razmjerno često zamjenjuje frikativom $h(200)$ :

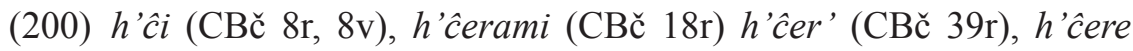
(CBč 42r); hêerami (CFat 1r), hĉi (CFat 1v, 79r), hĉeriû (CFat 37r), hcere (CFat 74r).

Do zamjenjivanja okluziva $k$ frikativom $h$ u Fatevićevu zborniku često dolazi i u slijedu dvaju okluziva $k t$ u primjeru dohtur (CFat 32r, 36v, 28r, 52r). U Fatevićevu zborniku česti su primjeri razjednačivanja nosnika na daljinu $(n . m>l . m)$ u primjerima zazlamenal $(\mathrm{CFat} 7 \mathrm{v})$, zlaminev (CFat 46r), zlami$n a($ CFat $47 \mathrm{v}) .{ }^{47}$ Slične su promjene i danas prisutne u čakavskim otočnim govorima zadarskoga područja (usp. primjere hćî, dohtũr u Kalima na otoku Ugljanu, prema BENIĆ 2013; zlamệne, döhtor u Zaglavu na Dugome otoku, prema ŠPRALJA 2016.b) pa ih zasigurno treba objašnjavati utjecajem narodnoga jezika.

\section{ZAKLJUČAK}

Provedena analiza pokazala je da se na fonološkoj razini i u Berčićevu i u Fatevićevu zborniku miješaju elementi narodnoga i crkvenoslavenskoga jezika, s tim da je obilježjā narodnoga jezika znatno više, a osobito se često i sustavno, kako smo i očekivali, ona pojavljuju u mlađem, Fatevićevu zborniku.

Jasan otklon u odnosu na hrvatskocrkvenoslavensko stanje u obama zbornicima predstavlja brojnost primjera u kojima je jat zamijenjen drugim fonemima. I u Berčićevu i u Fatevićevu zborniku jat se odrazio ikavsko-ekavski. Raspodjela odrazā pritom uglavnom slijedi pravilo Meyera i Jakubinskoga, uz stanovitu prevlast ikavskih odraza, što upućuje na južnije srednjočakavsko, po prilici zadarsko područje. Tradicionalni se grafem za jat u Berčićevu zborniku u dijelu primjera ipak bilježi na mjestu praslavenskoga jata, dok u Fatevićevu zborniku isti grafem nikada ne dolazi u tome položaju. Od znakova za polu-

$\overline{47}$ Takvih primjera ima i u Klimantovićevu zborniku I. (zlameniê RitKlim 28r, zlamenai RitKlim 32v), a MIHALJEVIĆ, A. (2014: 227) donosi i jednu potvrdu iz Života Marije Magdalene u Žgombićevu zborniku. 
glas u Berčićevu zborniku ostvaruju se štapić i apostrof, s tim da se potonji upotrebljava znatno češće, dok je u Fatevićevu zborniku potvrđen samo štapić, koji se rijetko i neredovito ostvaruje samo na kraju riječi. U jakome je položaju poluglas uglavnom dosljedno vokaliziran u obama zbornicima, dok je u slabome - uz tipične hrvatskoglagoljske iznimke kao što su položaj pred sufiksima -sk-i -stv-, primjeri tzv. čakavske jake vokalnosti (kadi 'gdje', mani 'meni') i prvi slog u primjerima tipa magla, tama - pretežno ispao (CFat) ili se na njegovu mjestu bilježi apostrof (CBč).

Odrazi su nosnih samoglasnika u obama kodeksima uglavnom očekivani. Stražnji se dosljedno odrazio kao $u$. Prednji je pak u glavnini primjera dao $e$, a iza palatala je, kao i danas u čakavskim govorima, nerijetko zamijenjen s $a$. Osobito je zanimljivo i za lokaliziranje nastanka zbornika važno da do prijelaza $e$ > $a$ nije došlo samo iza $\check{c}, \check{z}$ i $j$, nego i iza l, i to nakon prijelaza početne korijenske suglasničke skupine $\mathrm{kl} \mathrm{u} \mathrm{kl}$ (proklati). Prema stanju u današnjim čakavskim govorima, ali i starijim tekstovima, uključujući i zborničke neliturgijske tekstove, čini se da je u spomenutoj okolini e prelazilo u $a$ samo na zadarskome području pa se navedeni primjeri mogu smatrati snažnim dokazom o tome da su zbornici nastali upravo na tome području. Slogotvorno se $l$ u Berčićevu zborniku, kao i u drugim hrvatskoglagoljskim liturgijskim i neliturgijskim tekstovima, dobro čuva te se vrlo rijetko zamjenjuje s $u$, dok je u Fatevićevu zborniku ono samo iznimno očuvano i u golemoj se većini primjera na njegovu mjestu ostvaruje čakavski odraz $u$. Slično uglavnom vrijedi i za slogotvorno $r$, uz koje se u Berčićevu zborniku obično ostvaruje samo popratni štapić, dok u Fatevićevu zborniku, i to osobito u prijepisu Zrcala duhovnoga, uz $r$ nerijetko dolazi popratno $a$, koje po svoj prilici nije tek grafijska oznaka slogotvornosti sonanta $r$, nego se u govoru zapisivača zborničkih tekstova doista izgovaralo.

Druga se palatalizacija u očekivanim položajima uglavnom dosljedno provodi, no ima i suprotnih primjera, osobito u Fatevićevu zborniku, u kojem su pod utjecajem narodnoga jezika razmjerno često potvrđeni i primjeri neprovođenja druge palatalizacije u nominativu množine muškoga roda pridjeva i zamjenica zbog analoškoga ujednačavanja pridjevske paradigme. Odraz praslavenske skupine $* t j$ u obama zbornicima gotovo sigurno treba interpretirati kao $\dot{c}$, a odraz skupinā *stj i $*_{s k j}$ kao $\check{s} c ́$, s tim da redovito bilježenje potonjega odraza slovnom skupinom ш'山' u Fatevićevu zborniku predstavlja važnu grafijsku inovaciju u odnosu na stanje u drugim zborničkim neliturgijskim tekstovima i, dakako, hrvatskoglagoljskim tekstovima liturgijskoga sadržaja. Skupina * $d j$ u obama kodeksima pretežno ima čakavski odraz $j$, no u Berčićevu zborniku potvrđeno je i nekoliko primjera sa starocrkvenoslavenskim 
odrazom žd. Očit utjecaj narodnoga jezika u Fatevićevu zborniku predstavljaju primjeri provođenja sekundarne jotacije, kojih u Berčićevu zborniku nema. Jednačenje po zvučnosti i mjestu tvorbe u obama je zbornicima uglavnom dosljedno potvrđeno i u pismu, a nerijetko se bilježi i na granici riječi. Starocrkvenoslavenska je skupina vbs u Berčićevu zborniku dobro očuvana, dok u Fatevićevu zborniku ima mnogo primjera njezina premetanja, što je također inovacija čakavskoga postanja. Početna suglasnička skupina čbr-, poduprta stanjem u čakavskim govorima, i u jednome se i u drugome zborniku, kao i u drugim hrvatskoglagoljskim tekstovima, dosljedno čuva.

\section{IZVORI}

CBč = Zbornik u Berčićevoj zbirci br. 5, 15. st., Sankt-Peterburg, Rossijskaja nacional'naja biblioteka, sign. $B \check{c} 5$.

CFat = Fatevićev zbornik duhovnoga štiva, 1617. g., Zagreb, Arhiv HAZU, sign. IV a 124.

CGrš = Grškovićev zbornik, 16. st., Zagreb, Arhiv HAZU, sign. VII 32.

CIvan = Ivančićev zbornik, 14./15. st., Zagreb, Samostan franjevaca III. reda »Sv. Ksaver«.

CKol = Kolunićev zbornik, 1468. g., Zagreb, Arhiv HAZU, sign. III a 51 .

CPet = Petrisov zbornik, 1468. g., Zagreb, Nacionalna i sveučilišna knjižnica, sign. $R$ 4001.

CPetr = Petrinićev zbornik, 1503. g., Wien, Österreichische Nationalbibliothek, sign. Cod. Vindob. Slav. 78).

CTk = Tkonski zbornik, prva četvrtina 16. st., Zagreb, Arhiv HAZU, sign. IV a 120.

CŽg = Žgombićev zbornik, 16. st., Zagreb, Arhiv HAZU, sign. VII 30.

KKor = Korizmenjak III a 19, 15./16. st., Zagreb, Arhiv HAZU, sign. III a 19.

RitKlim = Klimantovićev zbornik I., 1501. - 1512. g., Zagreb, Samostan franjevaca III. reda »Sv. Ksaver«.

\section{LITERATURA}

BADURINA STIPČEVIĆ, V. 2013. Predgovor. V. Badurina Stipčević (prir.). Hrvatska srednjovjekovna proza I. Legende i romani. Zagreb: Matica hrvatska, 11-27.

BENIĆ, M. 2013. Fonologija i naglasak imenica u govoru mjesta Kali. Rasprave Instituta za hrvatski jezik i jezikoslovlje 39/1: 11-68.

BENIĆ, M. 2014. Opis govora Kukljice. Doktorski rad. Zagreb: Filozofski fakultet Sveučilišta u Zagrebu.

BLAŽEVIĆ KREZIĆ, V. 2016. Jezik Misala Dragutina Antuna Parčića. Doktorski rad. Zagreb: Filozofski fakultet. 
BODOR, T. 2013. Govor Veloga Lošinja. Kroatologija 4/1-2: 68-89.

BOŽIN, D. 2017. Rječnik i govor starih žitelja otoka Rave. Zadar: Ogranak Matice hrvatske u Zadru.

BZ. 2016. Glagoljski zbornik. XV. st., sv. I - II. A. Nazor (ur.). Zadar: Stalna izložba crkvene umjetnosti - Sveučilište u Zadru.

DÜRRIGL, M.-A. 2013. Stilske i kompozicijske značajke srednjovjekovnih apokrifa, vizija, prenja i Marijinih mirakula. M.-A. Dürrigl (prir.). Hrvatska srednjovjekovna proza II. Apokrifi, vizije, prenja, Marijini mirakuli. Zagreb: Matica hrvatska, 11-34.

DÜRRIGL, M.-A. 2017. Pouka o ovozemaljskom čistilištu iz Fatevićeva zbornika. Slovo 67: $23-43$.

CORIN, A. R. 1991. The New York Missal: A Paleographic and Phonetic Analysis. Columbus, Ohio: Slavica Publishers.

CORIN, A. R. 1993. Variation and Norm in Old Church Slavonic. Slovo 41-43: 155-196.

DAMJANOVIĆ, S. 1984. Tragom jezika hrvatskih glagoljaša. Zagreb: Sveučilišna naklada Liber.

DAMJANOVIĆ, S. 2008. Jezik hrvatskih glagoljaša. Zagreb: Matica hrvatska.

DAMJANOVIĆ, S. 2009. Staroslavenski i starohrvatski u hrvatskim srednjovjekovnim tekstovima. S. Damjanović (ur.). Povijest hrvatskoga jezika. 1. knjiga: Srednji vijek. Zagreb: Croatica, 351-403.

FRANOV-ŽIVKOVIĆ, G. 2016. Fatevićev zbornik duhovnog štiva. B. Bunčuga, J. Faričić, P. Kero (ur.). Riznica glagoljaške kulture i hrvatske pismenosti otoka Rave 3: Fatevićev zbornik duhovnog štiva (1617.). Zadar: Stalna izložba crkvene umjetnosti - Sveučilište u Zadru, 7-12.

FZ. 2016. Fatevićev zbornik duhovnog štiva. B. Bunčuga, J. Faričić, P. Kero (ur.). Zadar: Stalna izložba crkvene umjetnosti - Sveučilište u Zadru.

GALIĆ, J. 2016. Jednostavni glagolski oblici u Hrvojevu misalu i Hvalovu zborniku. T. Kuštović, M. Žagar (ur.). Zbornik u čast Stjepanu Damjanoviću. Zagreb: Odsjek za kroatistiku Filozofskoga fakulteta u Zagrebu - Hrvatska sveučilišna naklada, 119-138.

GADŽIJEVA, S. 2009. Zapažanja o pravopisu i fonologiji staroslavenskih alternacija $s n$ $\sim \check{s} n \dot{n}, z n \sim \check{z} n$, $s l \sim 5 \check{l} l$ u hrvatskom crkvenoslavenskom jeziku (prezentska paradigma). Slovo 59: 135-150.

GADŽIJEVA, S. 2012. Morfonologija prezentske paradigme u hrvatskom crkvenoslavenskom jeziku. Zagreb: Hrvatska sveučilišna naklada - Staroslavenski institut.

GLUHAK, A. 1993. Hrvatski etimološki rječnik. Zagreb: August Cesarec.

GMK Rava. 2016. Glagoljske matične knjige Župe Uznesenja Blažene Djevice Marije na Ravi 1613. - 1830. B. Bunčuga, J. Faričić, P. Kero (ur.). Zadar: Stalna izložba crkvene umjetnosti - Sveučilište u Zadru.

GRABAR, B. 1967. Apokrifna Djela apostolska u hrvatskoglagoljskoj literaturi: 1. Djela Andrije i Mateja u gradu ljudoždera, 2. Djela apostola Petra i Andrije. Radovi Staroslavenskog instituta 6: 109-208. 
GRABES, H. 1982. The mutable glass. Mirror-imagery in titles and texts of the Middle Ages and the English Renaissance (prev. G. Collier). Cambridge - London - New York - New Rochelle - Melbourne - Sydney: Cambridge University Press.

HCSL. 2014. S. Gadžijeva; A. Kovačević; M. Mihaljević; S. Požar; J. Reinhart; M. Šimić; J. Vince. Hrvatski crkvenoslavenski jezik. M. Mihaljević (prir.). Zagreb: Hrvatska sveučilišna naklada - Staroslavenski institut.

HERCIGONJA, E. 1970. Jezik glagoljaške neliturgijske književnosti 15. stoljeća i Petrisov zbornik. Doktorski rad. Zagreb: Filozofski fakultet Sveučilišta u Zagrebu.

HERCIGONJA, E. 1983. Nad iskonom hrvatske knjige. Rasprave o hrvatskoglagoljskom srednjovjekovlju. Zagreb: Liber.

HOLZER, G. 2011. Glasovni razvoj hrvatskoga jezika. Zagreb: Institut za hrvatski jezik i jezikoslovlje.

KAPETANOVIĆ, A. 2010. Odraz najstarije hrvatske pjesmarice (1380.) u petrogradskom Berčićevu zborniku br. 5 (XV. st.). Colloquia Maruliana 19: 19-29.

KAPETANOVIĆ, A.; D. MALIĆ; K. ŠTRKALJ DESPOT (prir). 2010. Hrvatsko srednjovjekovno pjesništvo. Zagreb: Institut za hrvatski jezik i jezikoslovlje.

KOSIĆ, I. 2010. Ivančićev zbornik: hrvatskoglagoljski neliturgijski rukopis iz XIV./XV. stoljeća. Doktorska disertacija. Zagreb: Filozofski fakultet Sveučilišta u Zagrebu.

KRMPOTIĆ, P. 2015. Epenteza dentala u hrvatskome jeziku. Rasprave Instituta za hrvatski jezik i jezikoslovlje 41, 2: 285-300.

KUŠTOVIĆ, T. 2013. Nepromjenjive riječi u Ivančićevu zborniku. R. Božić, S. Sambunjak (ur.). Zadarski filološki dani IV. Zbornik radova s Međunarodnoga znanstvenog skupa Zadarski filološki dani 4 održanoga u Zadru 30. rujna i 1. listopada 2011. Zadar: Sveučilište u Zadru, 207-228.

LAHIRI, A; J. HANKAMER. 1988. The timing of geminate consonants. Journal of Phonetics 16: 327-338.

LISAC, J. 2003. Hrvatska dijalektologija 1. Hrvatski dijalekti i govori štokavskog narječja $i$ hrvatski govori torlačkog narječja. Zagreb: Golden marketing - Tehnička knjiga.

LISAC, J. 2009. Hrvatska dijalektologija 2. Čakavsko narječje. Zagreb: Golden marketing - Tehnička knjiga.

LOZIĆ KNEZOVIĆ, K. 2016. O nekim fonološkim i leksičkim osobitostima hrvatskoglagoljskoga Zbornika fra Šimuna Klimantovića iz 1512. godine. Radovi Zavoda za hrvatsku povijest 48, 1: 37-63.

LUKEŽIĆ, I. 1990. Čakavski ikavsko-ekavski dijalekt. Rijeka: Izdavački centar.

LUKEŽIĆ, I. 2012. Zajednička povijest hrvatskih narječja. 1. Fonologija. Zagreb - Rijeka - Čavle: Hrvatska sveučilišna naklada - Filozofski fakultet u Rijeci - Katedra Čakavskog sabora Grobinšćine.

MATASOVIĆ, R. 2008. Poredbenopovijesna gramatika hrvatskoga jezika. Zagreb: Matica hrvatska.

MATASOVIĆ, R.; T. PRONK; D. IVŠIĆ; D. BROZOVIĆ RONČEVIĆ. 2016. Etimološki rječnik hrvatskoga jezika. 1. svezak: $A-N j$. Zagreb: Institut za hrvatski jezik i jezikoslovlje. 
MIHALJEVIĆ, A. 2014. Hrvatskoglagoljski Život Marije Magdalene u odnosu na latinski predložak. Ricerche slavistiche 12, 58: 213-293.

MIHALJEVIĆ, M. 1991. Generativna fonologija hrvatske redakcije crkvenoslavenskoga jezika. Zagreb: Filozofski fakultet, Odsjek za opću lingvistiku i orijentalne studije.

MIHALJEVIĆ, M. 1997. Jezična slojevitost Brevijara Vida Omišljanina iz 1396. godine. Filologija 29: 119-138.

MIHALJEVIĆ, M. 2002. Slavenska poredbena gramatika. 1. dio. Uvod i fonologija. Zagreb: Školska knjiga.

MIHALJEVIĆ, M. 2008. Udvojeni suglasnici (geminate) u hrvatskoglagoljskim tekstovima. B. Petrović, M. Samardžija (ur.). Vidjeti Ohrid. Referati hrvatskih sudionica i sudionika za XIV. Međunarodni slavistički kongres (Ohrid, 10. - 16. rujna 2008.). Zagreb: Hrvatsko filološko društvo - Hrvatska sveučilišna naklada, 43-64.

MIHALJEVIĆ, M. 2011. Bilješke o jeziku Drugog beramskog brevijara. Tabula 9: 126-139.

MIHALJEVIĆ, M. 2014. Slavenska poredbena gramatika. 2. dio. Morfologija, Prozodija, Slavenska pradomovina. Zagreb: Školska knjiga.

MIHALJEVIĆ, M. 2015. O jeziku Drugoga vrbničkoga brevijara. V. Badurina Stipčević, S. Požar, F. Velčić (ur.). Hrvatsko glagoljaštvo u europskom okružju. Zagreb: Staroslavenski institut, 535-575.

MILČETIĆ, I. 1890. Prilozi za literaturu hrvatskih glagolskih spomenika. Ivančićev zbornik. Starine JAZU 23: 39-79.

MILČETIĆ, I. 1902. Prilozi za literaturu hrvatskih glagoḷskih spomenika III. Hrvatski Lucidar. Starine 30: 257-334.

MILČETIĆ, I. 1955. Berčićeva zbirka glagoljskih rukopisa i štampanih knjiga u Lenjingradu. Radovi Staroslavenskog instituta 2: 93-128.

MLADINEO, N. 2015. La versione croata glagolitica del Testamento di Abramo (1): Stato della ricerca e pubblicazione dei manoscritti inediti. Slovo 65: 21-64.

MLADINEO, N. 2016. La versione croata glagolitica del Testamento di Abramo (2): Studio sinottico dei mss e confronto con il testo greco. Slovo 66: 1-64.

NAZOR, A. 2016. Berčićev zbornik br. 5. Hrvatski glagoljski rukopis iz 15. stoljeća. A. Nazor (ur.). Glagoljski zbornik. XV. st., sv. I. Zadar: Stalna izložba crkvene umjetnosti - Sveučilište u Zadru, 17-24.

PETEŠIĆ, I. 2017. Srednjovjekovni dugootočki Priručnik za svećenike. Disertacija. Zadar: Sveučilište u Zadru.

RADOŠEVIĆ, A. 2012. Korizmene propovijedi u Fatevićevu zborniku - prilog rekonstrukciji glagoljskoga korizmenjaka. Slovo 62: 101-210.

REINHART, J. 2012. Nauk sinu Vičerdovu u hrvatskoglagoljskoj književnosti. Slovo 62: 211-232.

SAMBUNJAK, S. 2001. Tkonski zbornik: hrvatskoglagoljski tekstovi iz 16. stoljeća. Transliterirao i popratne tekstove napisao: Slavomir Sambunjak. Tkon: Općina Tkon.

SHEVELOV, G. Y. 1964. A Prehistory of Slavic. The Historical Phonology of Common Slavic. Heidelberg: Carl Winter Universitätsverlag. 
SKOK, P. 1973. Etimologijski rječnik hrvatskoga ili srpskoga jezika. Knjiga treća: poni² $-\check{Z}$. Zagreb: JAZU.

STROHAL, R. 1915. Hrvatska glagoljska knjiga. Zagreb: Vlastita naklada.

ŠPRALJA, R. 2016.a. Fonologija govora Zaglava na Dugom otoku. Diplomski rad. Zadar: Sveučilište u Zadru.

ŠPRALJA, R. 2016.b. Vokalizam govora Zaglava na Dugom otoku. Čakavska rič 44, 1-2: $5-78$.

ŠTEFANIĆ, V. 1969. Hrvatska pismenost i književnost srednjeg vijeka. V. Štefanić, B. Grabar, A. Nazor, M. Pantelić (prir.). Hrvatska književnost srednjega vijeka, knj. 1. Od XII. do XVI. stoljeća. Zagreb: Zora - Matica hrvatska.

ŠTEFANIĆ, V. 1970. Glagoljski rukopisi Jugoslavenske akademije. II. dio. Zagreb: JAZU.

VIGATO, I. 2017. Glagoljske oporuke sa sjeverozapadnih zadarskih otoka. Zadar: Sveučilište u Zadru.

VJALOVA, S. O. 2006. Glagoličeske pamjatniki v hranilišćah Rossii. Slovo 54-55: 171194.

VJALOVA, S. O. 2016. Uvod. A. Nazor (ur.). Glagoljski zbornik. XV. st., sv. I. Zadar: Stalna izložba crkvene umjetnosti - Sveučilište u Zadru, 39-51.

VULIĆ, S. 2008. O govoru Turković Sela. Modruški zbornik 2: 3-29.

ŽUŽAK, V. 2016. Govor otoka Rave. B. Bunčuga, J. Faričić, P. Kero (ur.). Riznica glagoljaške kulture i hrvatske pismenosti otoka Rave 19, 4. Svaštice. Zadar: Stalna izložba crkvene umjetnosti - Sveučilište u Zadru, 7-127.

\section{Summary}

Josip Galić

\section{PHONOLOGICAL FEATURES OF THE MISCELLANY FROM BERČIĆ COLLECTION NO. 5 AND THE FATEVIĆ MISCELLANY OF SPIRITUAL TEXTS}

In this paper, the phonological features of the Miscellany from Berčic Collection No. $5\left(15^{\text {th }}\right.$ century) and the Fatević Miscellany of spiritual texts (1617) are analysed and mutually compared. In addition, the situation in both miscellanies is compared with the results of previous research of the phonological features of Croatian liturgical glagolitic texts and with the situation in other non-liturgical miscellanies. The analysis shows that mixing of the Church Slavonic and Croatian (Chakavian) elements is attested at the phonological level in both miscellanies, with Croatian (Chakavian) features being more frequent in both miscellanies, particularly in the younger Fatević's Miscellany. The Ikavian-Ekavian reflex of jat with the prevalence of Ikavian examples and the change $e>a$ after $l$, which is preceded by the change of the root consonant cluster $k l>k l$, provides a reliable indication that both miscellanies could have been written in the Zadar region, i.e. in the southern middle-Chakavian region.

Keywords: phonology, Chakavian-Church-Slavonic amalgam, non-liturgical miscellanies, Miscellany from Berčić Collection No. 5, Fatević Miscellany of spiritual texts 